UNIVERSIDADE DE SÃO PAULO

FACULDADE DE EDUCAÇÃO

\title{
EDUCAÇÃO E COMUNICAÇÃO: PELAS VIAS DE UMA DIDÁTICA DA OBRA DE ARTE
}

ELIANA GOMES PEREIRA POUGY 
Eliana Gomes Pereira Pougy

\title{
EDUCAÇÃO E COMUNICAÇÃO: PELAS VIAS DE UMA DIDÁTICA DA OBRA DE ARTE
}

\author{
Dissertação apresentada como parte dos requisitos \\ para obtenção do grau de MESTRE em EDUCAÇÃO, \\ FACULDADE DE EDUCAÇÃO, UNIVERSIDADE DE \\ SÃO PAULO, área de concentração PSICOLOGIA E \\ EDUCAÇÃO.
}

ORIENTADORA: Profa. Dra. Rosa Iavelberg

São Paulo 
Eliana Gomes Pereira Pougy

\section{EDUCAÇÃO E COMUNICAÇÃO - PELAS VIAS DE UMA DIDÁTICA DA OBRA DE ARTE}

Dissertação apresentada como parte dos requisitos para obtenção do grau de MESTRE em EDUCAÇÃO, FACULDADE DE EDUCAÇÃO, UNIVERSIDADE DE SÃO PAULO, área de concentração PSICOLOGIA E EDUCAÇÃO.

Aprovada em

\section{BANCA EXAMINADORA}

Profa. Dra. Sônia Maria Vanzella Castellar

Universidade de São Paulo - Faculdade de Educação - FEUSP

Profa. Dra. Maria Heloisa Pereira de Toledo Machado Universidade Federal Fluminense - Departamento de Cinema e Vídeo - UFF 


\section{DEDICATÓRIA}

Aos meus pais, Hélio e Ana, observadores atentos e cuidadosos.

Ao meu marido Rodrigo, amor da minha vida, companheiro compreensivo e carinhoso.

Aos meus filhos Henrique, Mariana e João Carlos, anjos sempre presentes em meu coração.

Ao meu grande amigo Luis Felipe Castro Alencastro, interlocutor e companheiro de viagem.

A todos os meus colegas de Pós, companheiros de jornada e de trabalho.

A todos os professores e professoras, os que eu conheço e os que não, batalhadores incansáveis desse mundo tão ingrato.

A todas as crianças, as criaturas mais adoráveis desse mundo. 


\section{AGRADECIMENTOS}

Agradeço à minha orientadora, Profa. Dra. Rosa Iavelberg, pela sua paciência e compreensão nesse percurso tão atribulado quanto prazeroso.

Agradeço aos meus professores, Profa. Dra. Flavia Schilling e Prof. Dr. Julio Groppa Aquino, pelos seus ensinamentos imprescindíveis.

Agradeço a meu marido, Rodrigo, pelo seu amor e pelo seu apoio indispensável.

Agradeço aos meus filhos, Henrique, Mariana e João Carlos, pelo seu amor, pela sua compreensão e pela sua paciência.

Agradeço ao amigo Luis Felipe Castro Alencastro, pela ajuda incomensurável. 


\section{RESUMO}

Trata-se de uma pesquisa teórica, de cunho filosófico-educacional, visando analisar o dispositivo saber-poder da didática e propor a base epistemológica para a construção de uma Didática da Obra de Arte. A partir da perspectiva pós-estruturalista, com destaque para a produção de Michel Foucault, busquei encontrar algumas condições enunciativas que produziram o sujeito que ensina como alguém que depende da comunicação e de seus meios para transmitir mensagens claras e verdadeiras. Isolei uma série histórica constituída pela Bíblia, pela Didactica Magna de Comenius, pelo $O$ Emilio de Rousseau e pelo Democracia e Educação de Dewey, entendendo-os como discursos que compartilham, a despeito de suas especificidades e diferentes objetos, o mesmo paradigma geral segundo o qual se estruturam os saberes científicos da comunicação. Conforme as idéias de Foucault, busquei, também, os efeitos dessas descrições na realidade, principalmente em relação à forma que essas descrições aparecem em sua materialidade. Concluí que, apesar das especificidades de cada uma das teorias pedagógicas, existe um aspecto que está presente em todas elas: o paradigma da comunicação como transmissão de mensagens, e, conseqüentemente, a idéia de ruído como uma exceção à regra. $\mathrm{O}$ paradigma da comunicação que entende o ruído como exceção faz parte de um outro paradigma mais forte e poderoso que sempre esteve presente no pensamento ocidental. O paradigma da disjunção, que preconiza a separação e a dicotomização entre sujeito e objeto do conhecimento, que preconiza a linguagem como representação do real e que não compreende toda a complexidade do pensamento humano. Entretanto, o ruído faz parte do processo de comunicação não como uma exceção, mas como uma regra. E como tal, possui sua especificidade e tem uma parte ativa no processo comunicacional. Por isso, também a partir da perspectiva pós-estruturalista, com destaque para a produção de Gilles Deleuze e Felix Guattari, propus a base epistemológica para a construção de uma Didática da Obra de Arte. Para tanto, resgatei as idéias de Deleuze e Guattari sobre linguagem, a palavra de ordem e a linguagem agramatical; as idéias de Maturana e Varella em relação ao aprendizado, a autopoiese; e as idéias de Pierre Lévy sobre inteligência, a inteligência coletiva. Segundo penso, assim como Deleuze afirmou que existe uma pedagogia que é do Conceito, existe uma Didática que é da Obra de Arte. Essa didática pode nos ajudar a compreender os momentos em que o processo de ensino e de aprendizado se processa entre o caos e o conhecimento, no mundo do ruído e da construção de sentido. Ela se caracteriza, principalmente, por compreender o entreensino.

Unitermos: filosofia pós-crítica, educação, comunicação, didática, ruído, análise do discurso, cinemapa, Pedagogia do Conceito, Didática da Obra de Arte. 


\section{ABSTRACT}

This is about a theorical research, built on educational-philosophical basis, viewing to analyse the know-power device of the didactics and propose the epitemological basis to the construction of a Didactics of the Master Piece. From the post structuralism perspective, outlining Michel Foucault's production, I tried to find some compositional conditions that produced the person that teaches as someone who depends on the communication and its means to transmit clear and true messages. I isolated a historical series formed by the Bible, by the Didactica Magna of Comenius, by Emile of Rousseau and by the Democracy and Education of Dewey, understanding them as speeches that share, despite of their specificities and diferent objects, the same general paradigm, according to wich is structured the scientific knowledge of the communication. Following the ideas of Focault I also searched the effects of this descriptions in reality, mainly relating to the form in wich these descriptions appear in their materiality. I concluded that in spite of the specificities of each one of the pedagogical theories there is an aspect present in all of them: the communication paradigm as message transmission, and consequently, the idea of a noise as exception to the rule. The communication paradigm that understands the noise as exception makes part of another paradigm more powerful and stronger, that has always been present in western thinking. The disjunction paradigm that proclaims the separation and the dichotomization between subject and object of knowledge, that proclaims the language as representation of the real and does not comprehend all the complexity of the human thinking. However, the noise makes part of a communication process not as an exception, but as a rule. As such, has its specificity and an active part in the communicational process. Because of this, also from the post structuralist perspective, outlining the production of Gilles Deleuze and Felix Guattari, I suggest the epitemological basis to the construction of a Didactics of the Master Piece. For this I rescued the ideas from Deleuze and Guattari on language, the word of order and the non grammatical language; the ideas from Maturana and Varella relating to the learning, the autopoiese, and the ideas of Pierre Lévy on inteligence, the collective inteligence. According to me, just like Deleuze affirmed that there is a pedagogy that comes from the Concept, there is the Didactics that comes from the Master Piece. This didactics can help us undesrtand the moments in wich the process of teaching and learning happens between the caos and the knowledge, in the world of noise and the sense construction. It is mainly caracterized by comprehending the inter-teaching

Keywords: post critical philosophy, education, communication, didactics, noise, speech analisys, cinemap, Pedagogy of the Concept, Didactics of the Master Piece 


\section{SUMÁRIO}

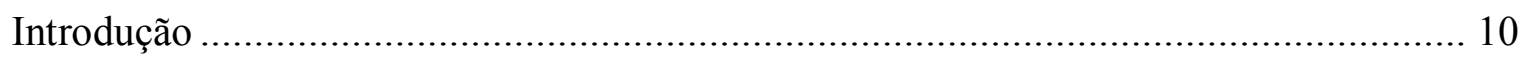

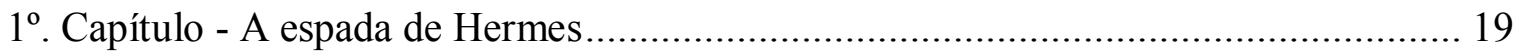

$1^{\circ}$.1. As teorias da comunicação .............................................................................. 20

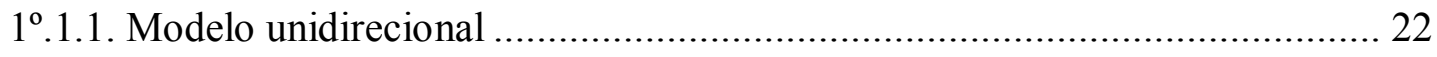

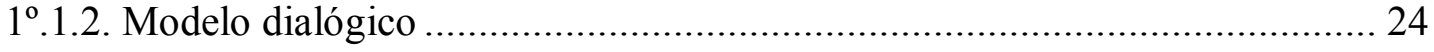

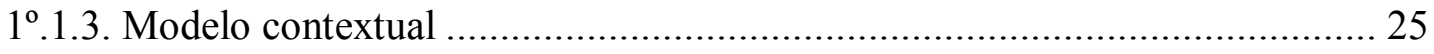

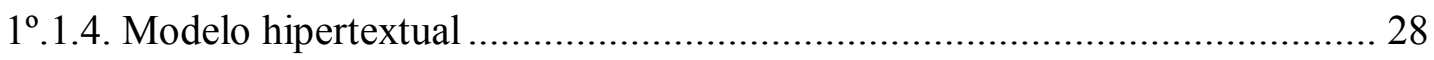

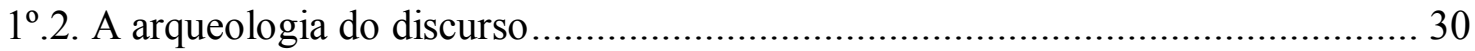

$1^{\circ}$.3. Primeiro movimento: a verdade está na palavra escrita....................................... 35

$1^{\circ}$.4. Segundo movimento: a verdade está na palavra escrita, porém adequada ........... 37

$1^{\circ} .5$. Terceiro movimento: a verdade não está na palavra, está na vida ....................... 45

$1^{\circ}$.6. Quarto movimento: a verdade está na cultura .................................................... 48

$1^{\circ} .7$. Quinto movimento: a verdade está na sociedade democrática e na luta de classes 53

$1^{\circ}$.8. Conclusão do $1^{\circ}$. capítulo - o sujeito didata e a linguagem representacional....... 62 $2^{\circ}$. Capítulo - A cabeça da Medusa .................................................................................. 70

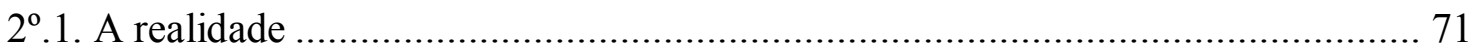

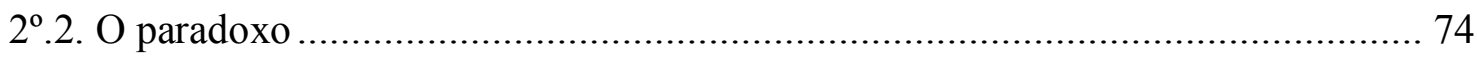

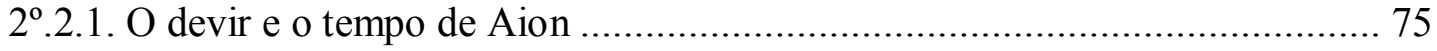

$2^{\circ}$.2.2. A linguagem na filosofia deleuzeana .......................................................... 79

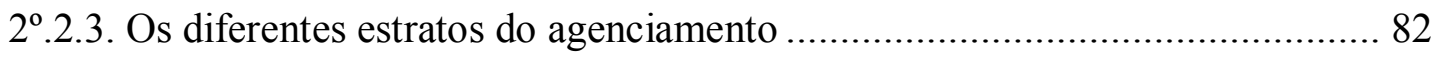

$2^{\circ}$.2.4. O pensamento complexo e a comunicação como redundância ...................... 85

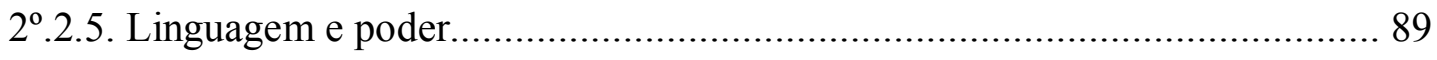

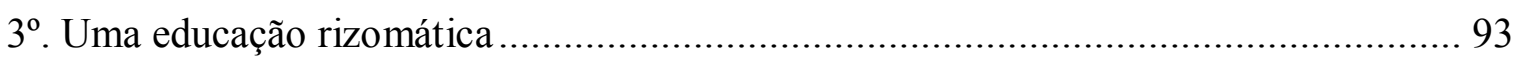

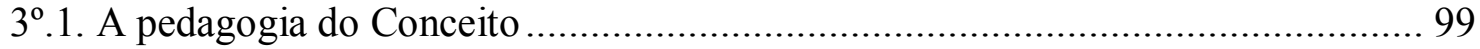

$3^{\circ}$.1.1. Currículo e pós-estruturalismo ................................................................103

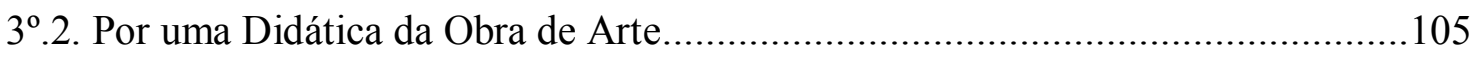

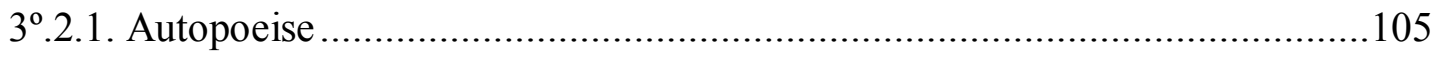

$3^{\mathrm{o}}$.2.2. Inteligência coletiva ……..................................................................107 


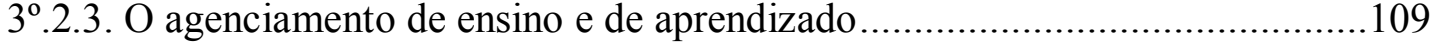

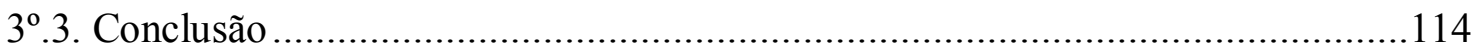

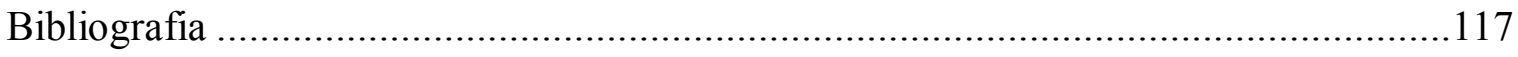




\section{INTRODUÇÃO}

[...] tenho medo do que é novo e tenho medo de viver o que não entendo-quero sempre ter a garantia de pelo menos estar pensando que entendo, não sei me entregar à desorientação.

Clarice Lispector

A Didática está em processo de mudança e este é um processo complexo porque ao mesmo tempo em que ela pretende dizer o que é a verdade, ela se pergunta por que tantos alunos têm tanta dificuldade para aprender. 
Em nossos dias, a ligação que existe entre educação e comunicação vem se estreitando cada vez mais, num movimento impulsionado, principalmente, pelas novas tecnologias de informação e de comunicação. Graças a essa nova capacidade tecnológica, as informações vêm sendo organizadas, armazenadas e postas ao alcance de quem quiser, ou puder, adquirí-las. Por isso, a grande questão do homem contemporâneo é o que fazer com as informações que recebe a todo o momento e em todo lugar: como selecioná-las, organizá-las, analisá-las e utilizá-las em seu cotidiano? Em outras palavras, como aprender com elas? Dessa maneira, a educação, em suas mais diversas formas, mantém-se, mais do que nunca, como a grande ferramenta social. A idéia de educação continuada, a vida toda, realizada de modo formal ou informal, vem se firmando de forma irreversível. Além do ensino praticado nas escolas públicas e particulares em todo o mundo, vê-se o ensino formal à distância ganhar força com a Internet e sua capacidade de interação e diálogo. A educação não-formal, fora da escola formal, vem crescendo ao mesmo tempo em que crescem a força das organizações não-governamentais e a participação da sociedade naquilo que era dever do Estado.

Assim, constata-se também que a maioria dos nossos espaços sociais acabou por se transformar numa imensa sala de aula. Como afirma o filósofo francês Michel Serres (1998), a sociedade contemporânea caracteriza-se por ser uma "sociedade pedagógica", ela se caracteriza por ser educativa. Dentro e fora dos muros da escola, a educação está presente em tudo o que chega até nós: objetos, imagens, sons, filmes, palavras. Uma rápida passada d'olhos nos sites da Internet, no catálogo das editoras ou na programação dos canais de televisão nos faz ver o quanto a produção cultural tem andado de mãos dadas com a didática. Segundo Serres (ibid.), o modelo pedagógico que está presente na distribuição da informação é o modelo da distribuição escolar, em sua forma mais tradicional.

E quanto à escola, instituição educativa da modernidade? Apesar da incômoda sensação de crise que se abate sobre as instituições modernas em geral, a instituição escolar continua forte. No Brasil, por exemplo, o número de escolas de ensino básico, entre instituições públicas e privadas, cresceu de algumas poucas dezenas no final do século XIX para 215.000 mil escolas em $2003^{1}$. E cada vez mais, essas instituições são estimuladas a mudar a sua ação, tornando o ensino uma "prática social concreta" (VEIGA, 1998, 51). Um dos objetivos dessa nova maneira de 
ensinar orienta o uso educativo das novas tecnologias de informação e de comunicação, e por isso, presenciamos um movimento crescente que leva os media ${ }^{2}$ para dentro da sala de aula. Dessa forma, eles vêm sendo encarados como um recurso didático indispensável.

Contudo, os media não possuem apenas aspectos educativos. Devido às grandes mudanças culturais e comportamentais ocorridas no século XX, e à liberdade concedida a toda forma de expressão, aos media foi permitida a veiculação de todo o tipo de conteúdo. Por isso, a “alfabetização para mídia", que visa a crítica à produção cultural mediática, é alvo de diversas ações que envolvem a escola. No Brasil, esse assunto vem sendo sistematizado pelo professor e jornalista Ismar de Oliveira Soares, considerado um dos mais profundos conhecedores das políticas de comunicação das Igrejas Cristãs no Brasil, especialmente da Igreja Católica Romana. A proposta do Núcleo de Comunicação e Educação da ECA-USP, sob coordenação do professor Ismar, é fazer com que a relação educação-comunicação seja tratada como uma área de conexão entre essas duas disciplinas e que ganhe o status de um novo campo epistemológico e de uma nova disciplina, a Educomunicação.

A justificativa para a criação desse novo campo é o fato de que o fruto da união desses dois saberes pode se transformar num novo recurso de intervenção histórico-social, possibilitando o nascimento de uma nova era, mais democrática, e de uma nova civilização potencialmente mais crítica, sobretudo nos países periféricos nos quais a pobreza e a sujeição cultural aparecem acentuadas pelas demarcações de um poder disciplinador. Ao estimular o uso de tecnologias de produção de discurso na escola, que não apenas a escrita, a educomunicação permite ao aluno a possibilidade de se transformar em sujeito da fala, aumentando sua capacidade de expressão e colocando-o diante de seus direitos, além de estimulá-lo a exercitar sua autonomia ${ }^{3}$.

Entretanto, uma observação mais atenta me fez ver que a relação educação-comunicação já vem sendo estudada por uma área da pedagogia há pelo menos três séculos, e essa área é a didática. A didática dirige e instrumentaliza o processo de ensino e de aprendizado. Por abordar

2 Nessa dissertação, utilizarei a expressão original inglesa media. Aqui, entendo como media todos os instrumentos criados pela tecnologia e que são usados para a comunicação entre pessoas, desde uma simples folha de papel impresso até o computador de ultima geração, ou seja, a tecnologia que pretende mediar o diálogo entre as pessoas. Outro termo comum que define a comunicação que utiliza a tecnologia é comunicação de massa. Entretanto, não o utilizarei porque ele remete a um modo de entender a sociedade e o processo de comunicação proveniente de uma visão de mundo que não consegue definir a comunicação como vem sendo realizada pela Internet e pela telefonia, por exemplo. Outro termo comumente usado e que não utilizarei é mídia. Essa palavra foi criada pela imprensa brasileira e não tem um significado claro.

3 Informação retirado do site do NCE (Núcleo de Comunicação e Educação): http://www.usp.br/nce/ 
as relações que ocorrem entre os elementos que constituem a prática pedagógica - o professor, os alunos, os conhecimentos, os procedimentos, os recursos e as tecnologias (DAMIS, 2004) -, podemos afirmar que a didática trata do modo como se ensinam os conteúdos e as disciplinas e cuida das técnicas que orientam a atividade educativa a fim de torná-la mais eficiente. Desse modo, possui uma relação intrínseca com as ciências da comunicação.

Mesmo que a didática, desde o final do século XX, busque "superar sua tendência técnica” (VEIGA, 2004, 51), faz parte de seu objeto de estudo a escolha, a justificativa e o uso de recursos técnicos e tecnológicos no processo de ensino e de aprendizado. Conclui-se, portanto, que é assunto da didática, ou da relação educação-comunicação, o ato educativo permeado pela racionalidade técnica. A razão técnica é aquela que faz a melhor adequação entre os meios e os fins escolhidos. Segundo Paulo Ghiraldeli Jr. (2002), a didática é a expressão pedagógica da razão técnica, e possui, sem sombra de dúvidas, uma imensa utilidade. Sem ela, os meios escolhidos para educar poderiam comprometer o aprendizado ao invés de efetivá-lo.

Entretanto, ao buscar dados sobre a educação contemporânea ${ }^{4}$, principalmente a brasileira, constatei que a didática não tem garantido o aprendizado de alunos envolvidos no processo educativo. Apesar do desenvolvimento técnico e científico da área, dos esforços dos professores e da capacidade de persuasão dos meios de comunicação e de informação presentes nas estratégias didáticas, existem momentos em que a didática não atinge seus objetivos e isso, invariavelmente, acaba resultando no baixo rendimento dos alunos.

Philippe Perrenoud (1999), em seu artigo Os Dez Não-Ditos ou a Face Escondida da Profissão Docente, nos fala sobre os pequenos fracassos cotidianos que assombram os professores, por mais competentes que eles sejam. Segundo o pedagogo, esses fracassos acontecem na sala de aula regularmente, e têm como conseqüência a não-efetuação do aprendizado dos alunos. São eles: o medo, a sedução negada, o poder vergonhoso, a avaliação todo-poderosa, o dilema da ordem, a bricolagem, a solidão ambígua, o aborrecimento e a rotina, a inconfessável distância e a liberdade sem responsabilidade. Para o pedagogo, esses fracassos, não-ditos pelos professores, não são exceções mas sim "regras comprovadas" (id., ibid.). Mesmo

4 Em seu livro A história da escola, em São Paulo e no Brasil, Maria Luiza Marcílio (2005) nos fala que uma das principais questões da educação contemporânea no Brasil é o fracasso escolar. E uma das maiores expressões desse fracasso está na repetência dos alunos. O Brasil foi considerado o campeão mundial em repetência, numa pesquisa realizada pela UNESCO, em 1997. 
que, segundo o autor, os dez não-ditos relacionados por ele sejam simplificações, o não-falar dos professores sobre esses pequenos fracassos cotidianos torna-se "um mecanismo comum de autoengano" (id., ibid.).

$\mathrm{Na}$ sala de aula social, a garantia do aprendizado também não existe. Na programação da tv, nas páginas das revistas, nos sites da internet, são transmitidos saberes, conceitos, valores e normas que também estão presentes na sala de aula escolar. Mas, justamente pelo fato da informação estar em toda parte, e surgir a todo o momento, o conhecimento se torna caótico. Por isso, podemos afirmar que vivemos a grande Biblioteca de Babel. Em seu conto Biblioteca de Babel, Jorge Luis Borges descreve um espaço tão grande que não pode ser percorrido e onde toda informação do mundo (e a desinformação também) está à disposição de todos, inclusive a história passada e futura de suas vidas e todas as suas diferentes vidas possíveis. Entretanto, a coleção desta biblioteca é tão vasta e avassaladora que encontrar algo de valor nela é quase impossível.

Dessa forma, cheguei à conclusão de que no processo de ensino e de aprendizado, tanto no espaço da sala de aula como fora dela, existe o lugar da "falta" de comunicação e do "excesso" de comunicação, ou seja, o lugar onde a comunicação, entendida como o processo de transmissão de mensagens, não acontece. Segundo a teoria da informação ${ }^{5}$, o ruído é a diferença entre a quantidade de informação emitida e a recebida. Quando ele surge, a comunicação não se dá e o feedback, isto é, a resposta do receptor à mensagem do emissor, também não se dá. No senso comum, pensa-se que o ensino foi insatisfatório quando a resposta do aluno, ou sua avaliação, não corresponde àquilo que foi transmitido pelo professor.

E, quando o ruído acontece na sala de aula, quando o caos parece se instalar, como bem disse Perrenoud (ibid.) ao tratar sobre o "dilema da ordem" - um dos dez não-ditos -, os professores tendem a pendular entre duas ações extremas: ou eles delimitam os conteúdos, tarefas e regras do jogo, numa forma de controle absoluto, ou eles deixam que as coisas aconteçam e enfrentam os acontecimentos da melhor forma, sem, contudo, deixar de sentir-se incompetentes.

A questão dessa ação contraditória do professor é alvo de vários artigos e pesquisas. Saviani, citado por Libâneo (1985), comenta sobre as confusões que se emaranham na cabeça dos professores quando eles buscam nas teorias pedagógicas as soluções para os problemas inerentes da prática pedagógica:

5 A teoria da informação, desenvolvida em 1948 pelo matemático Claude Shannon, será aprofundada no capítulo 1 dessa dissertação. 
Aí está o quadro contraditório em que se encontra o professor: sua cabeça é escolanovista, a realidade é tradicional; $[\ldots]$ rejeita o tecnicismo porque sente-se violentado pela ideologia oficial; não aceita a linha crítica porque não quer receber a denominação de agente repressor. (SAVIANI apud LIBÂNEO, ibid., 20)

Penso que, apesar das especificidades de cada uma das teorias pedagógicas e ações didáticas, existe um aspecto que está presente em todas elas: o paradigma da comunicação como transmissão de mensagens, e, conseqüentemente, a idéia de não-transmissão, ou de uma diferença entre o que se ensina e o que se aprende, como ruído. Um paradigma funciona como uma estrutura de pensamento arraigada, deriva de uma imposição dos detentores do saber oficial e resulta principalmente na conceituação do que é ou não verdade. O paradigma da comunicação entende o ruído como uma exceção, como algo que se deve negar e ocultar, ou mesmo "consertar" para que a transmissão das mensagens ocorra sem problemas. Entretanto, podemos afirmar que o ruído existe e faz parte do processo de comunicação não como uma exceção, mas como uma regra. E como tal, possui sua especificidade e tem uma parte ativa do processo de comunicação.

O paradigma da comunicação que entende o ruído como exceção faz parte de um outro paradigma mais forte e poderoso que sempre esteve presente no pensamento ocidental. $\mathrm{O}$ paradigma da disjunção ${ }^{6}$, que preconiza a separação e a dicotomização entre sujeito e objeto do conhecimento, que preconiza a linguagem como representação do real e que não compreende toda a complexidade do pensamento humano. Por isso, não é à toa que Philippe Perrenoud (op. cit.) chama a negação dos pequenos fracassos que acompanham o cotidiano docente de " $a$ comédia da dominação e da racionalidade”.

A didática, o modo como se ensina e se aprende, depende da pedagogia, ciência que abraça a racionalidade do processo educativo, e das ciências da comunicação, que abraçam a racionalidade do processo comunicativo. Tanto a pedagogia como as ciências da comunicação utilizam uma forma de razão que faz "a ponte" entre a prática e as idéias, ou seja, utilizam a razão enquanto razoabilidade, a razão que cria as teorias que dirigem a ação a um determinado fim. E

6 Abordarei esse assunto com mais profundidade no capítulo 2 dessa dissertação. 
quem escolhe os fins é a filosofia. A filosofia utiliza uma forma de razão que valora, que escolhe os fins e os valores. A filosofia diz os objetivos de uma teoria (pedagogia, comunicação) e de uma ação (didática). Como nunca, precisamos rever os objetivos e os valores que regem a educação e a comunicação, ou mesmo criar novos objetivos, buscar novos valores, criar novos conceitos sobre educação e sobre comunicação. Só assim, poderemos desenvolver um novo modo de entender e praticar a didática.

Quando decidi pesquisar a relação que existe entre a educação e a comunicação, duas áreas do saber que fazem parte de minha formação acadêmica e de minha vida profissional, acabei por descobrir novas idéias que vêm surgindo ${ }^{7}$ e que têm a filosofia da Diferença ${ }^{8}$ como base, principalmente de acordo com as idéias de Michel Foucault, Gilles Deleuze e Félix Guattari. Essa filosofia é interessante porque incita à criação de novos conceitos. A filosofia da Diferença faz uma crítica à linha filosófica historicista, como o positivismo e o marxismo. Ela vai contra a idéia de que filosofia é apenas refletir sobre alguma coisa que aconteceu. Na visão desses filósofos, e principalmente na óptica de Deleuze e Guattari, filosofia é criação de conceitos, principalmente porque tudo é criação, até mesmo a história. A história capta o que aconteceu, a efetuação de fatos, procedimentos, coisas, ela é o conjunto das efetuações num determinado contexto. Para eles, a filosofia, além de tratar do que aconteceu, também deve abraçar o devir, as possibilidades ainda não dadas como certas. Ela deve criar algo novo e chegar mais perto do que acontece na realidade.

A filosofia da Diferença faz parte de uma linha de pensamento que "quebrou" as concepções filosóficas e cientificas que eram tidas como verdadeiras. Essa quebra de paradigmas da ciência resultou em um novo modo de pensar que se caracteriza pela interdisciplinaridade e por novos modos de entender o que é sujeito e o que é objeto. A maior diferença entre o

7 Nos últimos anos a epistemologia da educação vem reconhecendo o caráter transdisciplinar da educação, sua incerteza e a busca do "conhecimento do conhecimento" (MORIN, 2002, 31) e a epistemologia da comunicação também vem buscando a formação de um campo acadêmico transdisciplinar e a afirmação de um "estatuto transdisciplinar da comunicação" (LOPES, 2003, 290), fazendo parte de um movimento contemporâneo crítico da compartimentação disciplinar que foi construída na história das ciências.

8 Segundo Marilena Chaú (2004), a filosofia da Diferença se interessa mais pela singularidade e particularidade e menos pelas semelhanças e identidades. Inspirando-se nos trabalhos dos antropólogos, interessa-se pela diversidade, pluralidade, singularidade das diferentes culturas, em lugar de voltar-se para a idéia de uma cultura universal que conteria dentro de si, como suas partes ou seus momentos, as diferentes culturas singulares. Além disso, em vez de buscar uma ciência universal que conteria todas as ciências particulares, interessa-se pela multiplicidade e pela diferença entre as ciências, pelos limites de cada uma delas e, sobretudo, por seus impasses e problemas insolúveis. 
pensamento que aceita a diferença e o pensamento científico clássico é em relação à causalidade dos fenômenos. Para a filosofia da Diferença, a causalidade é circular e o conhecimento é autoprodutivo, é autopoiético, ou seja, o efeito é ao mesmo tempo, causa.

Essa forma de pensar muda totalmente a conceituação de comunicação. Por seu caráter inovador, a filosofia da Diferença compreende alguns aspectos presentes na comunicação que as antigas teorias não conseguem explicar, como por exemplo, como se dá a comunicação quando ela é encarada como uma redundância de mensagens dentro de um sistema e não como uma transmissão de mensagens de um sujeito a outro. Conseqüentemente, essas novas idéias também me ajudaram a criar novos conceitos sobre a didática.

Assim, dividi minha dissertação em três capítulos: no primeiro, utilizando a perspectiva arqueológica de Michel Foucault, busquei encontrar algumas condições enunciativas que produziram o "sujeito que instrui", o sujeito "didata". Esses discursos produziram a idéia de didática como algo que transmite conhecimento verdadeiro através da comunicação e seus meios. Busquei também os efeitos dessas descrições na realidade, principalmente em relação à forma que essas descrições aparecem em sua materialidade. Resgatei discursos pedagógicos de diversos momentos históricos que compartilham, a despeito de suas especificidades e diferentes objetos, o mesmo paradigma geral segundo o qual se estruturam os saberes científicos da comunicação. Também em concordância com a perspectiva foucaultiana, minha busca não seguiu a seqüência histórica, propriamente dita, mas momentos de uma mesma formação discursiva.

No segundo capítulo, resgatei a filosofia de Deleuze e Guattari e suas idéias sobre a positivação do simulacro, o paradoxo do tempo de Aion, o paradoxo do devir, e sobre o uso da linguagem, a palavra de ordem e a linguagem agramatical. Além disso, em busca de uma nova visão sobre a comunicação, busquei as idéias de Ciro Marcondes Filho e sua Nova Teoria da Comunicação.

No terceiro capítulo, propus a base epistemológica de uma Didática da Obra de Arte. Essa didática tem por base a Pedagogia do Conceito, de Deleuze e Guattari, as idéias de Maturana e Varella em relação ao aprendizado, a autopoiese, e as idéias de Pierre Lévy sobre inteligência, a inteligência coletiva.

Segundo penso, a Didática da Obra de Arte pode nos ajudar a compreender os momentos em que o processo de ensino e de aprendizado se processa entre o caos e o conhecimento, no mundo do ruído e da construção de sentido. Ela caracteriza-se, principalmente, por compreender 
o entre-ensino. Deleuze (1998), em seu livro Diferença e Repetição, nos fala sobre um tipo de pensamento que se opõe à imagem dogmática, aquilo que ele chama de pensamento sem imagem: um pensamento que começa sempre pela diferença, no meio de alguma coisa, num eterno retorno do diferente. Por isso, a Didática da Obra de Arte enfatiza os movimentos de territorialização, desterritorialização e de reterritorialização. E esses movimentos são possíveis, principalmente, na sala de aula escolar. Assim, mais do que apenas defender a escola como o lugar da educação, aqui defendo a sala de aula escolar como o lugar da educação porque é nela que podem acontecer encontros que se dão longe tanto do caos (o abismo indiferenciado) como da Doxa (o senso comum, o bom senso e a anticriação) e de sua ferramenta mais importante, a comunicação. 


\section{1․ CAPÍTULO - A ESPADA DE HERMES}

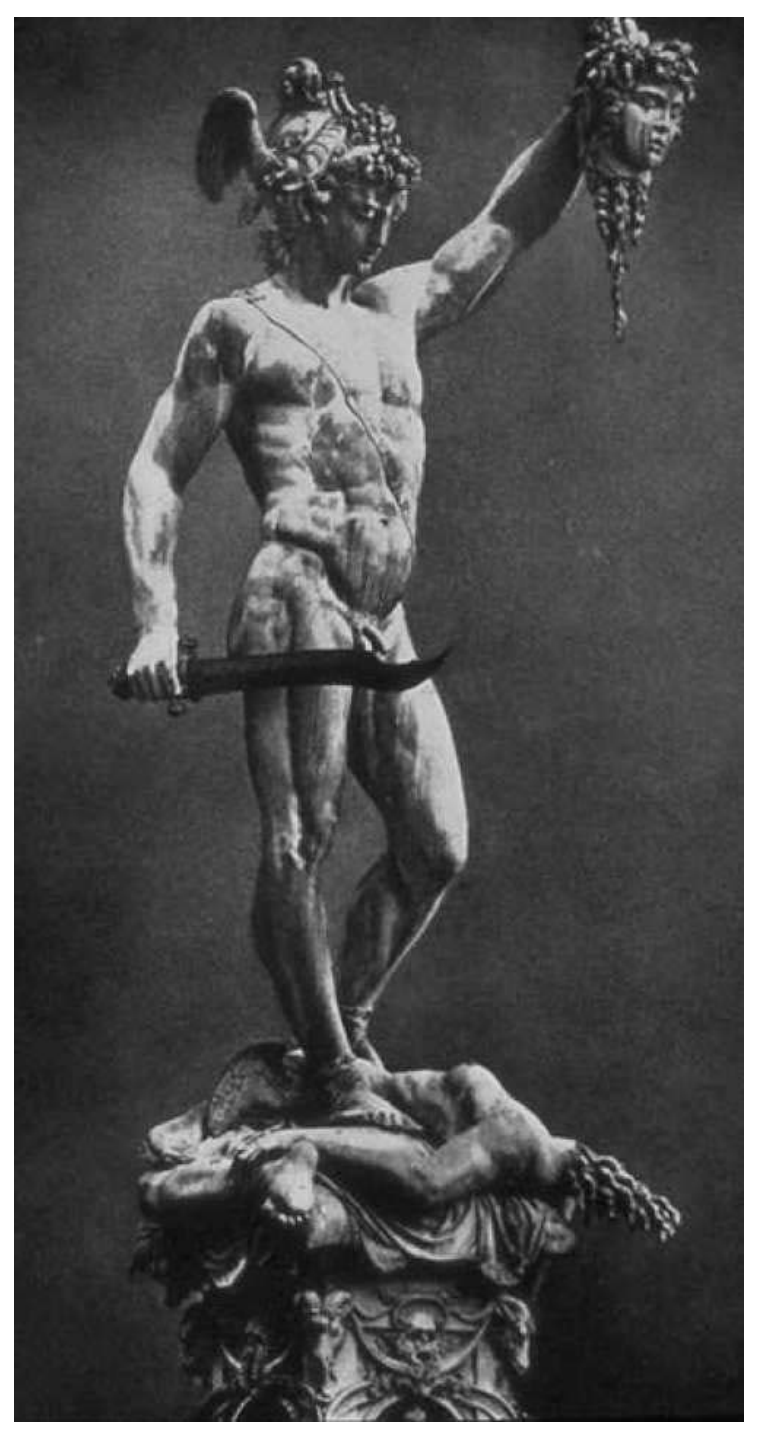

Perseu decapitando Medusa

Escultura em pedra

Benvenuto Cellini (1550 -1571) 


\section{$1^{\circ}$.1. AS TEORIAS DA COMUNICAÇÃO}

A filosofia moderna, ou a filosofia definida por Michel Foucault (2004) como analítica da finitude, surgiu quando Kant instaurou o homem como sujeito transcendental e como condição de todo o conhecimento possível. Acontece aí, então, o nascimento das ciências empíricas que se voltam para o homem como objeto de conhecimento e, a partir de seus temas, constatam a finitude própria do objeto de seu conhecimento. O pensamento moderno é uma analítica da finitude justamente por que coloca o homem ao mesmo tempo como sujeito e objeto de todo o conhecimento e, além disso, coloca-o como organizador do espaço de representação onde surgem esse sujeito e esse objeto (id., ibid.).

$\mathrm{Na}$ busca pela divisão disciplinar que caracteriza o pensamento moderno, as ciências da comunicação surgiram no final do século XIX. Foi nesse período que a comunicação se tornou uma disciplina acadêmica, buscando, assim, métodos científicos que explicassem o processo de comunicação entre seres humanos e entre seres humanos e máquinas que mediam esse processo. E foi a partir do século XX que a comunicação, algo que era da ordem interpessoal, ou no máximo de um sujeito falante a um pequeno grupo de pessoas, passou a ser do interesse coletivo. Com o advento dos meios de comunicação social, utilizados para unir uma sociedade cada vez mais urbana, populosa e dispersa nos espaços territoriais do mundo todo, surgem os primeiros estudos sobre o poder e a influência dos meios de comunicação em um grande grupo de pessoas, ou seja, a influência dos meios de comunicação na massa da população. As diversas teorias da comunicação, de diferentes maneiras, enfatizam o processo comunicacional e a relação dos elementos presentes nesse processo.

Entretanto, todas essas teorias possuem em comum um paradigma maior, presente no pensamento ocidental desde a Antiguidade. Esse paradigma possui a crença na preexistência da realidade frente à linguagem e faz da linguagem um instrumento de representação do real. Esse modo de pensar, presente no determinismo científico, opera com a causalidade e com a objetividade dos objetos e dos enunciados lingüísticos. Para esse pensamento, a linguagem é tida 
como algo natural e relativo à preexistência da realidade. A informação, por esse prisma, é uma representação das coisas do mundo, ela é um conjunto de códigos que representam as coisas e os pensamentos.

A comunicação, nesse sentido, é uma cadeia objetiva e linear que tem como elementos um emissor (que tanto pode ser um homem como uma máquina), que transmite uma informação codificada a um receptor (que tanto pode ser um homem como uma máquina), através de um canal, natural ou artificial. Para haver comunicação, o receptor deve possuir condições de decodificar a informação, ou seja, deve utilizar o mesmo código que o emissor. A etapa do processo que vai nos dizer se houve ou não comunicação - o entendimento da informação como pretendido - chama-se retroalimentação ou feedback.

Quando a decodificação não acontece, ocorre o ruído. Portanto, é o código comum que faz com que o fluxo da comunicação fique livre de ruídos. Por isso, na economia dos processos comunicacionais, uma informação pode ser mais ou menos codificável, ou seja, ela possui um determinado coeficiente de comunicação. A esse coeficiente dá-se o nome de redundância. Quanto mais redundante, mais decodificável é a informação. Esses são os principais elementos da teoria da informação desenvolvida pelo matemático Shannon, em 1940.

Essa forma de pensar fez com que, principalmente no século XX, buscássemos métodos para criar informações objetivas, claras, diretas. Esse modo de pensar considera o ruído, ou a falha na decodificação do código, um erro, algo ruim, improdutivo. E em nossa cultura, o ruído é ligado ao mal, ao caos, à desordem ${ }^{9}$.

Em linhas gerais, esse modo de pensar também baseia os esforços dos professores desde o surgimento da prática educativa formal, e mais enfaticamente, desde o surgimento da prática educativa presente na instituição escolar da era moderna. O que é alfabetizar, afinal? Ensinar às crianças um código comum para que elas possam participar da sociedade, fazer parte. Segundo os ideais modernos, esse é um direito de todos. E isso justifica todos os esforços empreendidos no decorrer do século XX para realizar uma "Escola para todos" e para ter "Todos na escola".

\footnotetext{
9 Aprofundarei esse assunto no capítulo 2 dessa dissertação.
} 
Podemos separar as teorias da comunicação em quatro grandes grupos:

\section{$1^{0}$.1.1. Modelo unidirecional}

Este modelo, totalmente de acordo com o paradigma comunicacional, compreende o processo de comunicação como uma linha reta, que tem como ponto de partida um emissor que envia uma mensagem a um receptor. Dessa forma, a causa do processo de comunicação é o emissor, que possui uma intenção de comunicar e uma informação (verdade, conceito, idéia, etc) que será recebida pelo receptor. Conseqüentemente, o receptor pode ser encarado como alguém manipulado pelo emissor.

Teoria da informação: como já foi dito, esta teoria, criada na década de 40 pelo matemático e engenheiro elétrico Claude Shannon, explica o processo da comunicação como uma linha reta que tem como ponto de partida o emissor, alguém que envia uma mensagem a um receptor. Desenvolvida nas primeiras décadas do século $\mathrm{XX}$, esta teoria busca respaldo nas pesquisas em biologia e Shannon declaradamente o retirou delas, principalmente nas pesquisas sobre o sistema nervoso (MATTELART, A. e M., 2002).

Teoria empírico-funcionalista: de base positivista, esta teoria foi desenvolvida por Paul Lazarsfeld e Elihu Katz, do Mass Communication Research, nos EUA, durante os anos 30. Herdeira direta das teorias psicológicas em voga no início do século XX - Psicologia das Massas, Behaviorismo e as teorias de Pavlov sobre reflexo condicionado - e da estreita associação entre ciência, moral e a política que lhes servia de base, a Mass Communication Research buscou entender de que modo a comunicação pode auxiliar no controle da vida social e em sua organização. Dessa forma, os media passaram a ser considerados como uma ferramenta de circulação eficaz dos símbolos, e o público passou a ser visto como um alvo que obedece cegamente ao estímulo-resposta (id., ibid.). Uma nova mentalidade foi desenvolvida com a transmissão de idéias em massa: 
[...] uma valorização da razão e da ordem; uma aversão à contradição; uma grande capacidade de distanciamento e de objetivação; uma tolerância à demora na resposta. (CASHMORE, 1994, 21).

Esses estudos possibilitaram o desenvolvimento de estratégias que pretendiam gerar efeitos comportamentais individuais que resultassem em comportamentos controlados dos grandes grupos sociais. Para tanto, o processo de comunicação deveria ser intermediado pelos formadores de opinião. Por isso, ela também é definida como "two steps flow of communication”. Foi nessa época que surgiram os institutos de pesquisa de opinião pública, que queriam entender as motivações e as necessidades das pessoas, para aplicá-las na comunicação.

Teoria crítica: esta teoria foi desenvolvida pela Escola de Frankfurt, na Universidade de Columbia, EUA. Este grupo de filósofos, originalmente formado no Instituto de Pesquisa Social, afiliado à Universidade de Frankfurt, na Alemanha, era de orientação marxista. O objetivo inicial desse instituto era estudar a economia capitalista e a história do movimento operário. Nos EUA, Theodor Adorno uniu-se ao grupo, formado por Max Horkheimer, Herbert Marcuse e Walter Benjamin. Adorno estudava os efeitos culturais dos programas musicais do rádio a pedido de Lazarsfeld, que buscava desenvolver uma convergência entre a teoria européia e o empirismo americano. Entretanto esse intuito não se realizou, pois Adorno não concordou com as aplicações práticas de suas pesquisas, aplicações essas que visavam a busca de maior audiência para as rádios. Através de uma crítica psicossociológica, Adorno criticou os programas musicais de rádio dizendo que eles faziam o indivíduo alienado se integrar ao status quo, e não buscar o saber e a resistência das culturas tradicionais, da arte da elite.

Armand e Michèle Mattelart (op. cit.) relatam que Horkheimer e Adorno, filósofos da Escola de Frankfurt, compartilhavam "o sentimento de desagrado a uma arte integrada ao sistema" (id, ibid., 77). Para eles, o desenvolvimento das tecnologias de comunicação tem relação com o sistema sócio-econômico no qual se inserem e, dessa forma, qualquer influência que a comunicação, e os media, possam exercer nos indivíduos é antecedida por um objetivo que está fora da comunicação, uma intenção de dominação por parte dos produtores. A comunicação e os media, inseridos na cultura e nos sistemas simbólicos, por essa via, são um agente do sistema 
social e um instrumento de alienação e de dominação das massas, que só têm uma saída contra a alienação: a conscientização e o consumo de obras de arte ao invés de produtos culturais mediáticos.

Em meados dos anos 40, Adorno e Horkheimer criaram o conceito de Indústria Cultural, indústria que transformava a cultura em mercadoria. Para eles, todos os produtos culturais que são veiculados pelos media possuem um ar de semelhança, um padrão, que satisfaria à demanda do homem médio e que seria o resultado de uma lei da evolução da tecnologia em relação à economia, em detrimento da liberdade.

Esses filósofos consideraram que existem duas modalidades de razão:

[...] a razão instrumental, que está a serviço da exploração e da dominação, da opressão e da violência, e a razão crítica, que reflete sobre as contradições e os conflitos sociais e políticos e se apresenta como uma força libertadora. (CHAUÍ, 2004, 82).

Segundo eles, a união arte-tecnologia sela a degradação do papel filosófico-existencial da cultura.

Outro filósofo importante da Escola de Frankfurt é Herbert Marcuse. Nos anos 60, esse filósofo influenciou sobremaneira a luta ideológica da época. Em seus estudos, ele pretendeu desmascarar as novas formas de dominação, que estão escondidas em um mundo cada vez mais tecnológico e científico, um mundo que subjuga o indivíduo.

Além desses filósofos, o filósofo Walter Benjamin também participou da Escola de Frankfurt, mas suas idéias serão vistas no tópico $1^{\circ} .1 .3$.

\section{$1^{\circ}$.1.2. Modelo dialógico}

Este modelo, também de acordo com o paradigma da comunicação, discorda do anterior por que considera que o processo de comunicação é uma troca: do mesmo modo que o emissor envia mensagens, o receptor responde com atos e/ou pensamentos. Por isso, para esse modelo, a 
causa do processo de comunicação é o emissor, em um momento, e o receptor em outro, como num diálogo.

Teoria dos sistemas: desenvolvida por Bertalanffy na década de 50, buscava "as interações entre os elementos mais do que as causalidades, e buscava apreender a complexidade dos sistemas como conjuntos dinâmicos de relações intercambiantes” (MATTELART, A. E M., 2002, 62). Suas idéias foram aplicadas nas ciências políticas e incrementaram a teoria da informação de Shannon em relação ao papel do feedback e da retroalimentação do sistema cultural constituído pelos media na sociedade.

A idéia de que a comunicação é um sistema social que se retroalimenta é a base da prática das agências de publicidade e do Ibope, que mede o índice de resposta do público consumidor de produtos culturais dos media. Essa idéia de resposta do receptor às mensagens veiculadas pelos media movimenta uma parcela considerável de nossa economia, ou seja, os gastos com publicidade e propaganda.

\section{$1^{\circ}$.1.3. Modelo contextual}

Aqui, o paradigma da comunicação ainda se mantém, mas, todos os elementos do processo são considerados: o emissor, o receptor, o canal, o ambiente, ou seja, este modelo compreende o contexto. Esse modelo entende que a comunicação é uma troca de mensagens, mas que cada elemento do processo possui um determinado "caráter" que pode influenciar ou não na decodificação que o receptor faz das mensagens enviadas pelo emissor.

Teoria da percepção: a preocupação com a classe subalterna, com o homem do povo, foi foco da filosofia de Walter Benjamin, filósofo da Escola de Frankfurt. Ao pesquisar sobre as novas formas de arte do final do século XIX, como a fotografia e o cinema, Benjamin resgatou o conceito grego aisthesis, o sentido originário de estética, redefinindo-a como "teoria da percepção". A fotografia e o cinema, nascidas da tecnologia de produção, transformaram o próprio conceito de arte. Benjamin percebeu o quanto, para a cultura das massas, a experiência e o uso eram mais importantes que a obra de arte, ao contrário da cultura culta (CHAUÍ, 2004, 279). 
Para o homem da massa, que vai ao cinema, que fotografa, a arte é para ser usada e sentida. Isso propõe o fim das separações e dos privilégios, uma verdadeira emancipação da arte que se transforma em percepção coletiva a partir das novas técnicas e da participação das massas, a possibilidade de libertar o passado oprimido. Portanto, suas idéias eram contrárias às de seus colegas da Escola de Frankfurt, que consideravam a arte das massas, dos meios de comunicação, alienante. Para Benjamin, o sentido não é produzido na solidão da leitura contemplativa, mas sim transformado pelo processo de produção da cultura, permitindo a criatividade e a capacidade de crítica da massa popular mesmo nos processos de percepção coletiva (id., ibid., 280).

Teoria dos meios: essa teoria foi desenvolvida na década de 60 por Marshall McLuhan, estudioso dos meios de comunicação, principalmente os meios aplicados à educação. Um dos aforismos mais conhecidos de McLuhan é “o meio é a mensagem”. Para ele, o conteúdo de uma mensagem não importa, pois ele depende do meio que veicula a mensagem. Por exemplo: as mesmas palavras, ditas numa conversa presencial, impressas em papel ou apresentadas na televisão fornecem três mensagens diferentes. Por isso, mais que mensagens, aquilo que é veiculado pelos meios de comunicação são as informações. Oral, escrito ou eletrônico, o meio de comunicação molda o modo como entendemos o mundo e o meio predominante de uma época domina as pessoas daquela época (id., ibid.).

Teoria das mediações: na década de 80, Jesus Martín-Barbero, a partir das idéias de Gramsci e de Walter Benjamin, teorizou sobre a dominação social com ênfase no poder dos meios de comunicação de massa. Para ele o conceito gramsciniano de hegemonia torna possível pensar o processo de dominação social como um processo em que uma classe hegemoniza na medida em que representa interesses que as classes subalternas também reconhecem de alguma maneira como seus.

Ao identificar traços da cultura popular na produção cultural dos meios de comunicação, principalmente nas telenovelas, Jesus Martín-Barbero teorizou que a cultura hegemônica dos meios de comunicação de massa incorpora constantemente as outras formas de cultura, sejam elas populares, alternativas ou locais. Para ele, isso faz com que exista uma identificação do público com os produtos culturais dos meios, identificação essa que é constantemente negociada, 
pois uma cultura hegemônica só consegue adesão da massa através da negociação e de um jogo onde as mediações estão presentes (SOUZA, 2001).

A teoria das mediações, desenvolvida por Jesus Martín-Barbero, refutou o conceito de processo de comunicação em que tudo transcorre entre emissores-dominantes e receptoresdominados, sem resistência por parte dos dominados e sem nenhum indício de sedução por parte dos dominadores, um processo em que a estrutura da mensagem não era trespassada por conflitos e contradições, como a teoria desenvolvida pela Escola de Frankfurt. Jesus Martín-Barbero, ao resgatar a autonomia da cultura em relação à ideologia, nos mostra que os sujeitos da cultura podem criar novos significados e mudar a vida cotidiana e as relações de poder.

O campo das mediações sociais ultrapassa o dos meios e veículos porque não se resume a eles... o conceito de mediação não tem ainda uma definição rigorosa e final nos estudos culturais latino-americanos, mas vem sendo traduzido como o esforço de identificar e captar as múltiplas ações, situações, tecnologias e circunstâncias que se colocam como categorias estruturantes do modo de ser e de viver das pessoas num tempo e espaço dados, ou seja, os sentidos sociais estruturantes da vida num contexto dado. (id., ibid., 32).

Teoria da análise da audiência: esta teoria, criada na década de 80 por Denis McQuail, professor emérito de Comunicação de Massa no Departamento de Ciência da Comunicação da Universidade de Amsterdã, desenvolveu-se a partir da teoria crítica, da semiologia, da análise do discurso e também de estudos etnográficos de usos dos media.

Do mesmo modo que a teoria das mediações, essa teoria questiona que há algo na comunicação que não estava sendo considerado: o poder da audiência de significar as mensagens da TV. Ela considera que o receptor interpreta as mensagens e assim, procura localizar a atribuição e a construção de significados dados pelo receptor na sua relação com os media. McQuail entende que há uma intenção do emissor na apropriação ideológica do símbolo e que a interpretação que o receptor faz inclui aceitar ou não a ideologia contida no símbolo, ou seja, o receptor negocia o sentido das mensagens enviadas pelo emissor (MATTELART, A. e M., 2002). 


\section{$1^{\circ}$.1.4. Modelo hipertextual}

Este modelo entende o processo de comunicação como uma rede onde o receptor tem a possibilidade de escolher as mensagens que estão disponíveis e que foram colocadas na rede por inúmeros emissores. Este é o modelo de comunicação usado para explicar as "navegações" pela Internet. Um leitor nunca poderá finalizar a sua estrutura do hipertexto, uma vez que ela muda constantemente, pois as mensagens são colocadas e retiradas do sistema a todo momento. Uma rede de comunicações é, portanto, um hipertexto no qual nem o receptor nem o emissor têm o controle substancial da mensagem e, por isso mesmo, ninguém tem uma responsabilidade substancial sobre ela.

Este modelo foi a mola propulsora que fez com que o paradigma da comunicação fosse questionado. Na rede, o ruído existe, de forma insistente e regular. A partir da criação do espaço virtual, o ruído passou a fazer parte do processo de comunicação como algo real e até mesmo, político. A Internet é de todos que possuam um computador pessoal e um modem e, por isso, dizse que a Internet não tem dono. Essa liberdade de acesso proporciona as ações dos hackers, os piratas digitais, que acessam os sites das grandes empresas e dos governos "invadindo" o ciberespaço, interferindo no processo de comunicação de dados, criando um ruído com claras intenções políticas.

Análise da rede de comunicação: segundo esta teoria, criada nos anos 80 por Everett Rogers, professor da Universidade do Estado de Michigan, a rede de comunicação se compõe de indivíduos que estão conectados entre si por fluxos estruturados. Assim, segundo Rogers, é possível identificar os grupos de afinidade (subsistemas de comunicação no interior do sistema geral), os indivíduos-pontes (que ligam um ou mais grupos de afinidades) e os indivíduosligações (que ligam entre si um ou mais grupos de afinidade). Dessa forma, Rogers propõe a união da pesquisa crítica (baseada na teoria crítica) e da pesquisa empírica (baseada na teoria empírico-funcionalista) em comunicação, pois ela integra o contexto e os aspectos éticos do processo de comunicação à pesquisa de dados. Essa teoria busca, sobretudo, uma visão harmônica da sociedade, propondo um igualitarismo pela comunicação (id., ibid.). 
Todas essas teorias foram aplicadas basicamente em três frentes: nas ciências políticas, seja ela estatal, através da propaganda; seja ela empresarial, através da publicidade; na indústria cultural, indústria que cria, produz e comercializa objetos culturais; e na educação, principalmente na área da pedagogia que estuda os métodos de ensino e de aprendizado, a didática. 


\section{1‥2. A ARQUEOLOGIA DO DISCURSO}

Neste primeiro capítulo utilizei a perspectiva arqueológica de Michel Foucault. Aqui, busquei os discursos pedagógicos de diversos momentos históricos que compartilham, a despeito de suas especificidades e diferentes objetos, o paradigma geral segundo o qual se estruturam os saberes científicos da comunicação. Também em concordância com a perspectiva foucaultiana, essa busca não seguiu a História, propriamente dita, mas buscou momentos de uma mesma formação discursiva.

A filosofia foucaultiana insere-se na linha filosófica pós-crítica, também chamada de pósestruturalista. De acordo com os estudos do Estruturalismo, o sujeito é a primeira pessoa do verbo, aquele que diz "Eu penso". Ou seja, o sujeito é uma realidade puramente lingüística. Não é

essência, não é Idéia, não é ser. É um lugar no discurso. É por causa do pronome Eu que o tempo fundamental é o presente, que se organizam os pronomes demonstrativos e que se organiza toda a linguagem e os signos lingüísticos. Ou seja, "o sujeito do conhecimento é uma posição vazia, um modo de falar, uma disponibilidade do discurso" (CHAUÍ, 2005, 211).

A partir dessas idéias, em meados do século XX, Michel Foucault definiu em seu trabalho filosófico que, da mesma forma que o sujeito do saber é um efeito do discurso, o objeto do saber também o é. Dessa forma, aquilo que encaramos como verdade, acaba, também, por ser um efeito do discurso. Além disso, segundo Foucault (2004), as verdades só podem alcançar a coerência de determinado discurso se estiverem presentes em determinados campos do enunciado. Um enunciado não é uma frase, uma palavra ou um sintagma. O enunciado é uma função enunciativa do discurso:

[...] é uma função de existência que pertence, exclusivamente, aos signos, e a partir da qual se pode decidir, em seguida, pela análise ou pela intuição, se eles 'fazem sentido' ou não, segundo que regra se sucedem ou se justapõem, de que são signos, e que espécie de ato se 
encontra realizado por sua formulação. Não há razão para espanto por não se ter podido encontrar para o enunciado critérios estruturais de unidade; é que ele não é em si mesmo uma unidade, mas sim uma função que cruza um domínio de estruturas e de unidades possíveis e que faz com que apareçam conteúdos concretos, no tempo e no espaço. (id., ibid., 99).

Para Foucault (ibid.), um enunciado não é apenas uma proposição lógica ou um ato de linguagem, ele só é enunciado, ele só constituirá sentido, se possuir um conjunto de condições de existência. Segundo ele, um enunciado possui como espaço de correlações um conjunto de domínios em que os objetos podem aparecer, sendo que esses objetos podem ser reais ou fictícios.

Está antes ligado a um 'referencial' que não é constituído de coisas, de fatos, de realidades, ou de seres, mas de leis de possibilidade, de regras de existência para os objetos que aí se encontram nomeados, designados ou descritos, para as relações que ai se encontram confirmadas ou negadas. (id., ibid., 103).

O enunciado possui um sujeito que não necessariamente é o autor do texto, e sim, o sujeito do enunciado. Esse sujeito é:

[...] um lugar indeterminado e vazio que pode ser efetivamente ocupado por indivíduos diferentes. [...] esse lugar é uma dimensão que caracteriza toda formulação enquanto enunciado, constituindo um dos traços que pertencem exclusivamente à função enunciativa e permitem descrevê-la. (id., ibid., 108). 
Além desses aspectos, a função enunciativa possui um domínio associado, ou seja, um enunciado só existe se estiver inscrito num campo associado. Esse campo é uma trama complexa que torna possível o próprio enunciado. Ele é constituído:

[...] pela série das outras formulações, no interior das quais o enunciado se inscreve [...] pelo conjunto das formulações a que o enunciado se refere [...] pelo conjunto das formulações cuja possibilidade ulterior é propiciada pelo enunciado e que podem vir depois dele como sua conseqüência [...] pelo conjunto das formulações cujo status é compartilhado pelo enunciado em questão [...] pode-se dizer, de um modo geral, que uma seqüência de elementos lingüísticos só é enunciado se estiver imersa em um campo enunciativo em que apareça como singular. (id., ibid., 112113).

Da mesma forma, para que um enunciado possa ser considerado como verdade, é necessário que ele tenha uma existência material. E essa materialidade o constitui:

Composta das mesmas palavras, carregada exatamente do mesmo sentido, mantida a sua identidade sintática e semântica, uma frase não constitui o mesmo enunciado se for articulada por alguém durante uma conversa, ou impressa em um romance; se foi escrita um dia, há séculos, e se reaparece agora em uma formulação oral. As coordenadas e o status material do enunciado fazem parte de seus caracteres intrínsecos. (id., ibid., 115).

A materialidade de um discurso é constitutiva do próprio enunciado, porque ele possui uma substância, um suporte, um lugar, uma data. Se esses requisitos se modificam, o enunciado muda. Em seu artigo A sociedade pedagógica, Serres (1998) nos alerta que os métodos de ensino atuais, que utilizam as mais modernas tecnologias da comunicação e da informação, têm sua 
origem na Grécia, com a paidéia. Desde que a educação passou a formar o homem e o cidadão gregos e a englobar toda a cultura, o ensino foi instituído a partir de um intercâmbio de mensagens através de "meios sofisticados, de mensageiros leais e de códigos regulados" (id., ibid.).

Esta tradição, de onde emerge o ensino a distância, nós mesmos podemos escandir. Porque a cada mudança de suporte correspondeu um renascimento radical no ensino: à emergência da escrita corresponde, pelo menos em nossa cultura, a invenção da paidéia grega; no Renascimento, o aparecimento da tipografia deu uma nova imagem à pedagogia [...] A emergência atual das novas tecnologias coroa, em terceiro lugar, esta série, começada na aurora da história e que prossegue na idade das grandes descobertas. Elas transformam três coisas: objetivamente, os estoques do saber, menos concentrados doravante que distribuídos; subjetivamente, as faculdades humanas, dado que a memória, por exemplo, mergulha nos computadores, como, outrora e recentemente, ela mergulhava nas prateleiras ou nos livros; por último coletivamente, uma vez que aparece o que acabo de nomear como sociedade pedagógica. (id., ibid.).

Portanto, nos próximos tópicos desse capítulo, analisei não só a descrição simbólica e lingüística da relação educação-comunicação, mas também os efeitos dessas descrições na realidade, principalmente em relação à forma que essas descrições aparecem materialmente, em relação à sua materialidade. Além disso, resgatei os discursos pedagógicos que, a despeito de suas especificidades e diferentes objetos, possuem o mesmo paradigma geral da comunicação e, assim, constroem o sujeito "didata". Esses discursos estão presentes na Bíblia, na Didactica Magna de Comenius, n'O Emilio de Rousseau e no Democracia e Educação de Dewey. Cada um deles, em sua especificidade, está inscrito numa mesma série regular de acontecimentos que se refere à produção do sujeito que ensina através das mensagens "verdadeiras e justas" transmitidas pelos livros, e, mais tarde, pelos fascículos, pelos programas de rádio, pelos programas de 
televisão e pelas páginas da internet. Além disso, esses discursos apontam para a equivalência entre ruído na comunicação e erro, considerando-o como uma exceção à regra, algo que precisa ser anulado e corrigido pelo professor, responsabilizando, assim, o sujeito que ensina pelo sucesso e pelo fracasso do aprendizado do aluno. 


\section{1․3. PRIMEIRO MOVIMENTO: A VERDADE ESTÁ NA PALAVRA ESCRITA}

Colossenses 3, 2-4

Oração e sabedoria - Sejam constantes na oração; que ela os mantenha vigilantes, dando graças a Deus. Ao mesmo tempo, peçam por nós [apóstolos], para que Deus nos abra uma porta para a pregação, a fim de anunciarmos o mistério de Cristo, por quem estou preso. Peçam para que eu anuncie esse mistério com linguagem conveniente. (Bíblia Sagrada, 1990)

Depois da morte e da ressurreição de Cristo, a Paulo, um de seus apóstolos, foi dada a missão de levar a palavra de Deus aos pagãos de todas as comunidades da Palestina. Para tanto, Paulo criou a comunicação escrita para o Novo Testamento e foi seu principal escritor. Suas cartas, escritas antes dos capítulos dos outros apóstolos, nos mostram um mestre severo e carinhoso. Paulo era Mestre e Fariseu, especialista no cumprimento de toda a Lei judaica e seus pormenores. Depois que se converteu ao cristianismo, passou a anunciar a Palavra de Deus e a relatar a vida de Jesus.

Para o apóstolo, anunciar o Evangelho era uma obrigação, ensinar era cumprir uma ordem divina e, por isso, fazia-o gratuitamente. Naquele tempo, diz a introdução às cartas de Paulo, o Evangelho escrito não existia, e Paulo o levava

[...] impresso em sua carne, marcada por toda sorte de sofrimento, a ponto de estar crucificado com Cristo, trazendo em seu corpo as marcas da paixão de Jesus, e completando, no seu corpo, o que falta das tribulações de 
Cristo. Assim ele pode dizer que já não é ele que vive, mas é Cristo que vive nele. É assim que ele anuncia o evangelho. (id., ibid.)

Essas palavras, retiradas da Bíblia, nos fazem perceber a força da escrita em quem ensina. Por isso, não foi à toa que o livro, que surgiu a partir da segunda metade do século $\mathrm{XV}$, foi o principal instrumento didático do ensino humanista. Para os humanistas o saber estava na palavra de Deus escrita na Bíblia e, portanto, para se alcançar o saber era preciso ler. Maria Luiza Marcílio (2005), em seu livro A história da escola em São Paulo e no Brasil, nos conta que por volta de 1500, os livros já eram objetos de uso cotidiano da elite européia. Na cultura humanista da Idade Média, a educação era feita de forma elitista e de caráter religioso, quase um catecismo, e repousava na aprendizagem das línguas antigas, como o latim e o grego. Isso ocorria porque, para os humanistas, essas línguas davam acesso à herança cultural da Antiguidade. Para tanto, o medium era o livro.

Aos poucos, um abismo foi cavado entre as culturas popular e erudita, pois a cultura da elite era fundada em princípios "novos" enquanto a cultura popular se mantinha tradicional e oral. O plano de instrução era consubstanciado na Ratio Studiorum, cujo ideal era a formação do homem universal, humanista e cristão. A ação pedagógica dos jesuítas privilegiava o exercício da memória e o desenvolvimento do raciocínio, e compreendia o estudo privado orientado pelo mestre, as aulas expositivas, a repetição, o desafio, a disputa entre alunos, os exames orais e escritos. 


\section{1‥4. SEGUNDO MOVIMENTO: A VERDADE ESTÁ NA PALAVRA ESCRITA, PORÉM ADEQUADA}

\section{FUNDAMENTO IX}

Fundamento IX: É necessário evitar as coisas contrárias.

57. A natureza evita diligentemente as coisas contrárias e prejudiciais.

Com efeito, a ave, enquanto chocando-os, aquece os ovos, protege-os do vento forte, bem como da chuva e do granizo. Além disso, afasta do ninho as serpentes, os abutres e outros animais nocivos.

58. Também o arquiteto, tanto quanto lhe é possível, conserva seca a madeira, os tijolos e a cal, e não deixa cair nem arruinar-se aquilo que já construiu.

59. De igual modo, o pintor protege do vento, do calor intenso, da poeira e das mãos de estranhos um retrato ainda fresco.

60. O jardineiro, com a ajuda de uma paliçada ou de uma sebe, protege das cabras e das lebres as plantas jovens.

Aberração.

61. Comete-se, portanto, uma imprudência todas as vezes que, logo no início do estudo de uma nova disciplina, se propõe aos alunos uma matéria controversa, isto é, sempre que se levanta uma dúvida acerca da matéria que devem ainda estudar. Efetivamente, a que equivale isso senão a dar 
fortes sacudidelas numa plantazinha desejosa de lançar as raízes? Hugo escreveu com razão: «Nunca chegará a atingir a verdade, aquele que começar a instruir-se com controvérsias». Comete-se também uma imprudência quando se não afasta a juventude dos livros torpes, cheios de erros e de confusões, assim como também das más companhias.

Correção.

62. Pense-se, portanto, que é essencial:

I. Não dar aos alunos nenhuns outros [sic] livros, além dos da sua classe.

II. Que esses livros sejam tão cuidadosamente ilustrados que, justa e merecidamente, possam ser considerados verdadeiros inspiradores de sabedoria, de moralidade e de piedade.

III. Não devem ser toleradas nas escolas, ou nas vizinhanças das escolas, companhias dissolutas.

Conclusão.

63. Se todas estas regras forem observadas escrupulosamente, será quase impossível que as escolas falhem na sua missão. (COMENIUS, 2001)

Quinze séculos mais tarde que Paulo, em 1621, na Moravia, atual República Tcheca, Comenius, pastor da Igreja Reformada, reinscreveu a escritura na ação de educar, agora impressa em folhas de papel ricamente ilustradas. Em busca de um método de ensino que evitasse "as coisas contrárias", "prejudiciais", um método de ensino que protegesse "as plantas jovens" e transformasse o aprendizado em algo "rápido, agradável e completo", Comenius orientou os professores a seguir os passos da natureza e a prestar atenção na mente das crianças e no modo como os estudantes aprendem. Entre essas idéias estavam: o respeito ao estágio de desenvolvimento da criança no processo de aprendizagem, a construção do conhecimento através da experiência, da observação e da ação e uma educação sem punição, mas com diálogo, exemplo, ambiente e material didático adequado. 
Na visão de seu Tratado da arte de ensinar tudo a todos, os livros são considerados “inspiradores de sabedoria”, desde que adequados à idade do aluno, com conteúdo correto, "sem erros nem controvérsias" (id., ibid.). Dessa forma, sua didática introduziu uma novidade para a época porque recomendava aos professores que, "para não falhar em sua missão”, as crianças lessem apenas livros que fossem escritos para as crianças. Assim, no século XVII nasce uma produção cultural especializada em ajudar o professor a ensinar "tudo a todos", de mãos dadas com a invenção de uma infância ao mesmo tempo inocente, ao mesmo tempo culpada, e que deveria estar na escola para ser "curada" de seu mal original, o pecado (CORAZZA, 2002).

Um dos primeiros livros dirigidos ao ensino de crianças, e ricamente ilustrado, $O$ mundo dos sentidos em pinturas, foi escrito por ninguém menos que Comenius. Também foi nessa época que foram publicados os Contos da Carochinha, do francês Perrault, trazendo traduções das narrativas de tradição oral, tais como Chapeuzinho Vermelho, A Bela Adormecida no Bosque, A Gata Borralheira, O Pequeno Polegar.

Os países protestantes foram os primeiros a criar instituições públicas de ensino primário para a população mais carente. Em 1763, Frederico II, dos Estados Alemães, decretou a obrigatoriedade escolar universal e uniforme e a realização de um plano de estudos de oito anos, a partir das idéias de Comenius (MARCILIO, 2005). Assim, constatamos que o discurso didático de Comenius insere-se no momento em que uma nova ordem social e econômica instaura a força do Estado, responsabilizando a escola, e o professor, pela educação das crianças e adultos, agora alçados à condição de cidadãos. A primeira forma de Estado surgido na modernidade é o Estado Liberal, que nasceu a partir das idéias da Doutrina Liberal, a teoria da legitimidade civil. Segundo essa doutrina, criada em meados do século XVII, o Estado pode garantir os direitos dos indivíduos porque entre ele e os indivíduos existe a sociedade civil organizada. Dessa forma, é papel do Estado garantir as relações sociais e arbitrar seus conflitos, por meio de leis, da força e da garantia da liberdade de pensamento. O Estado garante a ordem pública (CHAUÍ, 2004).

Na França, nos séculos XVII e XVIII, aconteceu uma grande revolução no ensino com a criação das escolas lassalistas. Nessas escolas, o professor ensinava para uma classe de 50 a 60 alunos ao mesmo tempo. Dessa forma, os livros passaram a ser mais e mais popularizados e utilizados em sala de aula, incrementando a produção destinada ao publico infantil e a produção de livros feitos especialmente para o ensino. No século XVII, nas salas de aula de Lisboa e do Recife, por exemplo, os padres ensinavam por compêndios próprios e em português. Havia uma 
cartilha para as primeiras letras, um catecismo, um compêndio de História do Antigo e do Novo Testamento, um compêndio da História de Portugal e um compêndio das Obrigações Civis dos Homens.

Foi também nessa época que as primeiras ações do governo brasileiro em relação à educação popular foram realizadas. Em 1759, o Marquês de Pombal, primeiro-ministro de Portugal, expulsou os jesuítas do Brasil e realizou uma reforma dos estudos menores, introduzindo o ensino público nos domínios de Portugal, conforme os ideais do Iluminismo português, fortemente fisiocrata, mercantilista e reformista, e extremamente nacionalista e humanista. O iluminismo priorizava o ensino enciclopédico, pois tinha a preocupação de classificar e atualizar o saber (MARCILIO, 2005).

Com a vinda da Corte para o Brasil, em 1808, abriram-se perspectivas inovadoras para o ensino público brasileiro, que até aquele momento não existia de fato. Entretanto, nem com a presença do rei de Portugal o ensino foi regulado no país. "Ensinava cada um do modo que parecia cômodo e não havia método nem sistema, ou plano organizado pelo governo" (D’AZEVEDO apud MARCILIO, ibid., 34). Até o final do século XIX, quando D. João VI permitiu a imprensa no Brasil, os livros eram poucos, trazidos pelos filhos da elite que iam estudar na Europa, ou pelos professores vindos de lá, ou através de contrabando. A primeira gráfica brasileira surgiu somente em 1808, no Rio de Janeiro. E foi somente em 1825 que São Paulo ganhou sua primeira biblioteca pública (id., ibid.).

Foi em meados do século XIX que o método Lancaster chegou ao Brasil. Esse método, desenvolvido na Inglaterra, utilizava a ajuda de monitores, alunos mais velhos que auxiliavam o professor, e descartava os castigos físicos, utilizando apenas os castigos morais. Os militares foram os primeiros a utilizar esse método no país e ele acabou por tornar-se obrigatório nas poucas escolas brasileiras da época.

Em 1827, o ensino no Brasil era essencialmente laico e público. As poucas escolas privadas eram da Igreja. Mesmo depois da Independência, e apesar da criação da primeira faculdade no país, a qualidade do ensino ainda era sofrível. Por isso, a elite brasileira ensinava seus filhos a ler e escrever em casa. Marcílio (op. cit.) nos conta que educação era feita pela mãe ou por um preceptor particular, um sacerdote que passava a morar na residência da família. Quando alcançavam idade para isso, iam estudar na Europa. Ao povo, restava o ensino público que, como vimos, mal existia. 
A partir de 1870 tem início a Ilustração brasileira, de cunho liberal, positivista e cientificista. Lentamente, no início, e acelerando de forma dramática durante o século XX, as escolas, tanto públicas quanto privadas, foram instaladas no imenso território brasileiro, e a importância e a valorização do ensino foi emergindo no país. A explosão de escolas mudou o cotidiano das famílias brasileiras.

Dessa forma, a educação brasileira insere-se naquilo que Foucault (1999) chamou de poder disciplinar. Através de seu método de pesquisa histórica, a genealogia, o filósofo verificou que as técnicas dessa forma de poder eram centradas no corpo individual: a separação, o alinhamento, a colocação em série, a vigilância, além da organização desses corpos, com o fim de lhes aumentar a força útil através do exercício, do treinamento. Eram técnicas de racionalização e de economia de um poder que possuía sistemas de vigilância, de hierarquia de inspeções, de escriturações e de relatórios. Para esse poder, Foucault desenvolveu uma metáfora, o panóptico: um dispositivo de controle prisional criado no século XVIII, que ficava no centro do pátio da prisão: todos os vigiados viam o panóptico, mas não viam quem estava dentro do panóptico, a vigiar. O poder disciplinar, que ainda acontece em nossos dias, rege a multiplicidade dos homens individualmente através do treinamento, da vigilância. Ele se dá a nível local, no âmbito das instituições como a escola, o hospital, o quartel, a oficina, etc...

A partir do final do século XIX, quando os Estados Nacionais passaram a reivindicar seu papel na formação das novas gerações, o livro escolar transformou-se num verdadeiro símbolo da soberania nacional (CHOPPIN, 2002). O livro escolar, o chamado livro didático, é uma tradução de um programa ou de um currículo de ensino, e é o suporte mais utilizado pela escola para a transmissão de conteúdos. Ele põe em prática os métodos de aprendizagem que visam favorecer a aquisição do conhecimento, entretanto, também carrega consigo uma desvalorização da autonomia do professor, e a sujeição de alguém que ensina às idéias de outrem. Dessa forma, o professor passa a ser encarado como alguém que não sabe decidir sobre o conteúdo a ser ensinado e o método de ensino mais adequado à sua classe.

O livro, mais do que apenas ser o meio para a transmissão de uma mensagem de um emissor a um receptor, faz parte de um modelo de comunicação que utiliza um formador de opinião para mediar o processo. Nesse caso, o editor. Os primeiros editores, profissionais que fazem a ponte entre o autor e a produção de seu livro, eram também os primeiros tipógrafos. Era sua função escolher o tipo de letra, o papel e o formato do livro, e era sua função, também, 
escolher o autor que seria publicado. Dessa forma, podemos reconhecer no advento do livro um modo novo de transmissão de mensagens que, além de se constituir como uma mensagem de emissor a um receptor através de um meio, também é mediada por um formador de opinião que decide o que se deve comunicar. Esse mediador, invariavelmente, tem o poder nas mãos.

Por isso, o Estado passou a regular essa produção. No Brasil, em 1918, foi criada a primeira comissão para avaliação dos livros a serem usados em sala de aula. Essas eram as orientações do Secretário do interior de 1927:

Linguagem progressivamente enriquecida, correta, clara e elegante. Assunto acessível ao entendimento das crianças e não menos capaz de lhe concorrer para a formação da mentalidade e do caráter. Condições tipográficas boas e de agrado. ${ }^{10}$

Mais tarde, a atribuição de regular e controlar a produção editorial passou a ser do Instituto Nacional do Livro (INL). O INL foi criado em dezembro de 1937 por iniciativa do ministro Gustavo Capanema.

A indústria de livros do século XX encontrou na escola, e nos alunos e professores, seu público consumidor mais importante e invadiu "a escola através de material pedagógicodidático” (MEDRANO; VALENTIM, 2001, 72). A cada ano, as editoras passaram a lançar inúmeros livros voltados ao ensino. Dentro desses livros, estão presentes:

[...] programas curriculares destinados aos professores, definindo seus conteúdos, estratégias e recursos a serem usados, deixando pouca ou nenhuma liberdade de trabalho para o profissional, tolhendo sua criatividade e desempenho. Em decorrência disso, perdas são inevitáveis: o aluno deixa de ser beneficiado por aquilo que o professor poderia oferecer, alem do sugerido, e o professor acaba se

10 Relatório do secretário do Interior, 1927-28, apud MARCÍLIO, 2005, 187 
tornando acrítico, desempenhando seu trabalho simplesmente para cumprir obrigações. (id., ibid., 72).

O sistema apostilado, que atualmente vem substituindo quase que totalmente o livro didático, foi a materialização do discurso da modernização do ensino buscada no decorrer do século XX. Suas maiores justificativas foram o fato de ser prático, racional e economicamente viável. Entretanto, este material é alvo de inúmeras críticas porque acaba por reproduzir a estrutura social dominante, ao não dar chance para o professor criar. Além disso, por sua estrutura textual, fragmenta o conhecimento, impedindo a ação reflexiva (MOTTA, 2001).

A indústria de livros escolares e didáticos move grande parte da produção editorial:

É impossível para o historiador do livro tratar da atividade editorial da maior parte dos países sem levar isso em conta: em um país como o Brasil, por exemplo, os livros didáticos correspondiam, no início do século $\mathrm{XX}$, a dois terços dos livros publicados e representavam, ainda em 1996 aproximadamente a $61 \%$ da produção nacional. (CHOPPIN, 2002).

Em 1985, foi instituído o Plano Nacional do Livro Didático (PNLD). Com o objetivo de distribuir gratuitamente livros escolares aos estudantes matriculados no ensino fundamental das escolas públicas, o PNLD contribui para universalizar e melhorar o ensino de $1^{\mathrm{a}}$ a $8^{\mathrm{a}}$ série, promove a valorização do magistério, conferindo ao professor a tarefa de escolher o livro didático. Segundo o site do Fundo Nacional de Desenvolvimento da Educação (FNDE) ${ }^{11}$, o programa é administrado pelo FNDE, com o financiamento do Salário-Educação e recursos do Orçamento Geral da União.

Entre os anos de 1994 e 2003, o PNLD adquiriu, para utilização nos anos letivos de 1995 a 2004, um total de 915,2 milhões de unidades de livros, distribuídos para uma média anual de 30,8 milhões de alunos, matriculados em cerca de 172,8 mil escolas públicas de ensino fundamental. Nesse período, o PNLD investiu R\$ 3,2 bilhões.

11 Site do Fundo Nacional de Desenvolvimento da Educação: www.fnde.gov.br 
O Ministério da Educação e Cultura (MEC) também está empenhado em aumentar o número de estudantes beneficiados. Para isso, em 2004, criou o Programa Nacional do Livro para o Ensino Médio (Pnlem), que prevê a distribuição de livros didáticos para os alunos do ensino médio público de todo o País.

Em 2005, o PNLD distribuiu 110.643.113 livros didáticos para o ensino fundamental das escolas públicas de todo o País, beneficiando 31 milhões de estudantes, e, pela primeira vez, 1,3 milhão de alunos da primeira série do ensino médio de 5.392 escolas das regiões Norte e Nordeste receberam 2,7 milhões de livros das disciplinas de português e de matemática - um investimento de $\mathrm{R} \$ 38,4$ milhões. 


\section{1․5. TERCEIRO MOVIMENTO: A VERDADE NÃO ESTÁ NA PALAVRA, ESTÁ NA VIDA}

Transformemos as nossas sensações em idéias, mas não saltemos dos objetos sensíveis aos objetos intelectuais. É pelos primeiros que chegamos aos últimos. Nas primeiras operações do espírito que sejam os sentidos os seus guias. Nenhum outro livro que não seja o do mundo, nenhuma outra instrução que não seja a dos fatos. [...]

O espírito do meu sistema não é o de ensinar à criança muitas coisas, mas o de não deixar entrar no seu cérebro senão idéias justas e claras. Mesmo quando não saiba nada, pouco importa, desde que não se engane, e se lhe incuto verdades é apenas para garantir dos erros que poderia aprender em seu lugar. A razão, o juízo vêm lentamente; os preconceitos acorrem em multidão: é deles que é necessário preservar a criança.

O problema não é ensinar-lhe as ciências, mas darlhe o prazer de amá-las e os métodos para aprende-las, quando esse gosto estiver já bem mais desenvolvido. É este o princípio fundamental de toda boa educação. [...]

Nossos verdadeiros mestres são a experiência e o sentimento, e nunca o homem sente melhor o que mais convém ao homem do que nas relações em que ele mesmo se encontra.[...]

Não gosto das explicações em forma de discurso; os moços prestam pouca atenção e não as retêm. Coisas, coisas! Nunca repetirei de modo suficiente que damos importância 
demais às palavras. Com nossa educação palradora só fabricamos palradores.

Odeio os livros, eles apenas ensinam a falar daquilo que não se conhece. Mas, já que nos é absolutamente necessário ter livros, existe um que fornece, ao meu ver, o mais perfeito tratado de educação natural.

Qual é esse livro maravilhoso? Alguma obra de Aristóteles? De Plínio? Seria algum livro de Buffon? Não. - é o "Robinson Crusoé".

O nosso grande cuidado deve ser o de afastar do espírito da criança todas as noções de relações sociais que não estejam ao seu alcance; mas quando o encadeamento dos conhecimentos vos força a mostrar-lhe a mútua dependência dos homens, em lugar de mostrá-la sob o aspecto moral, dirigi a sua atenção para a indústria e para as artes mecânicas que tornam os homens úteis uns aos outros.

Há um certo apreço pelas diferentes artes, apreço que está em razão inversa da sua utilidade real. Este apreço se mede diretamente sobre a sua própria inutilidade. (ROUSSEAU, 1762)

Um século depois de Comenius, em 1762, Rousseau preconizava uma educação naturalista, que não significava o retornar a uma vida selvagem, primitiva, isolada, mas sim, o afastar dos costumes da aristocracia da época, da vida artificial que girava em torno das convenções sociais. A educação deveria levar o homem a agir por interesses naturais e não por imposição de regras exteriores e artificiais, pois só assim, o homem poderia ser o dono de si próprio. Rousseau trouxe novas idéias para combater aquelas que prevaleciam há muito tempo em sua época, principalmente a de que a educação da criança deveria ser voltada aos interesses da vida adulta. Introduziu a concepção de que a criança era um ser com características próprias em suas idéias e interesses, e desse modo não mais podia ser vista como um adulto em miniatura. Para ele, a criança não é educada para Deus, nem para a vida em sociedade, mas sim, para si mesma. 
Além disso, ao elevar as artes do povo - a serralharia - ao mesmo nível das artes da elite a ourivesaria - Rousseau se insere num novo momento do jogo político, aquele que buscava a liberdade, a igualdade e a fraternidade, e a ascensão da burguesia.

Nesse momento, Rousseau propunha aos professores não utilizar os livros para educar. Exceto um. Ele elege Robinson Crusoé como o único livro que podia ensinar algo às crianças, um livro que conta a história de um náufrago que tenta criar uma réplica física e moral do mundo que ele deixou para trás ao explorar o trabalho de Sexta-feira, o bom selvagem. Entretanto, a natureza o engole, e lhe mostra a verdade mais pura: servo e amo são iguais.

O discurso didático de Rousseau muda o foco do trabalho do professor, transformando-o em um observador, em alguém que alimenta a curiosidade do aluno e o faz compreender "idéias justas e claras", "sem ouvir nenhuma palavra" de sua boca; um professor que não corrige os erros dos alunos, nem o repreende. Alguém que ensina apenas pelos sentidos, sem palavras: "Não gosto das explicações em forma de discurso; os moços prestam pouca atenção e não as retêm. Coisas, coisas! Nunca repetirei de modo suficiente que damos importância demais às palavras" (id., ibid.). Para o filósofo a natureza ensina a justiça e a clareza por si mesma.

O filósofo propõe uma comunicação muda, uma comunicação pela percepção, pela sensação. Entretanto, suas idéias eram tão radicais para a época, e também para os nossos dias, que não foram aplicadas nem em seu país, a França, que depois da Revolução Francesa buscou uma educação democrática. 


\section{1‥6. QUARTO MOVIMENTO: A VERDADE ESTÁ NA CULTURA}

[...] Educação e Comunicação - É em verdade tão óbvia a necessidade de ensinar a aprender para a continuação da existência social, que há de parecer estarmos a repisar desnecessariamente um lugar-comum. Justificamo-nos, porém, com a circunstância de que, com essa insistência, nos libertaremos de uma noção imprópria escolástica e formal da educação. As escolas são, com efeito, um meio importante de transmissão para formar a mentalidade dos imaturos; mas não passam de um meio relativamente superficial. [...] A sociedade não só continua a existir pela transmissão, pela comunicação, como também se pode perfeitamente dizer que ela é transmissão e é comunicação [grifos do autor] [...]

[...] Em resumo - não somente a vida social exige o ensino e o aprendizado para sua própria continuação, como também por si mesma ela é educativa. Amplia e ilumina a experiência; estimula e enriquece a imaginação; gera o sentimento da responsabilidade, obrigando-nos a falar e a pensar com cuidado e exatidão. (DEWEY, 1979, 4-6)

A educação é para a vida social aquilo que a nutrição e a reprodução são para a vida fisiológica. A educação consiste primariamente na transmissão por meio da comunicação. A comunicação é o processo da participação da experiência para que se torne patrimônio comum. [...] É o mesmo que dizer-se que, embora toda a organização social produza efeito educativo, esse efeito começa a tornar-se parte importante dos fins sociais, quando se tem em vista a associação dos elementos mais velhos com os mais novos. (id., ibid., 10) 
Todavia, poder-se-á perguntar de que maneira esse princípio da atividade compartilhada se pode aplicar à apreensão, por exemplo, por meio da palavra falada ou escrita, da idéia de um capacete grego, caso em que não se verifica nenhum uso direto? Que atividade compartida existirá no aprender-se em livros a historia da descoberta da América? (id., ibid., 16)

[...] ao tornar-se a sociedade mais complexa, cumpre proporcionar um ambiente social especial que se dedique especialmente a desenvolver as aptidões dos imaturos. Três das mais importantes funções deste meio especial: simplificar e coordenar os fatores da mentalidade que se pretenda desenvolver; purificar e idealizar os costumes sociais existentes; criar um meio mais vasto e melhor equilibrado do que aquele pelo qual os imaturos, abandonados de si mesmos, seriam provavelmente influenciados. (id., ibid., 24)

O fim da educação é conseguir esta direção interna por meio de identidade de interesse e compreensão. Os livros e a conversação podem fazer muito, mas o mal é contarmos excessivamente com esses fatores. Para sua plena eficiência, as escolas precisam de mais oportunidades para atividades em conjunto, nas quais os educandos tomem parte, a fim de compreenderem o sentido social de suas próprias aptidões e dos materiais e recursos utilizados. (id., ibid., 42)

Dois séculos e meio mais tarde que Rousseau, no começo do século XX, John Dewey, um dos maiores pedagogos americanos, contribuiu intensamente para a divulgação dos princípios do que se chamou Escola Nova. Dewey não aceitava a educação pela instrução, unicamente, propondo a educação pela ação; e criticava severamente a educação tradicional, principalmente no que se refere à ênfase dada ao intelectualismo e a memorização, e à sua materialidade, os livros.

Em seu discurso, ele indica para o sujeito que ensina a pedagogia da sociedade, porque a sociedade comunica. Ao comunicar, ela mostra a necessidade da educação e a importância do 
papel do sujeito que ensina, porque ele é o mediador entre a vida e o aluno. O professor ideal, segundo essas idéias, é aquele que retira os recursos didáticos da vida em sociedade, ou seja, os recursos didáticos presentes na cultura, e não apenas os recursos didáticos feitos especialmente para o ensino, como os livros didáticos, por exemplo. $\mathrm{Na}$ visão de Dewey, todas as produções culturais presentes na sociedade podem ajudar o professor em sua missão de educar. Entretanto, o mais interessante no discurso de Dewey é que ele não se dirige em nenhum momento ao professor. Ele é dirigido a quem comanda o professor, o Estado.

No Brasil, o século XX foi marcado por inúmeras reformas de ensino. A idéia de reforma nasceu entre os marxistas que buscavam a mudança social do capitalismo para o comunismo através de etapas históricas. Segundo eles, o socialismo, ou a socialdemocracia, é uma dessas etapas. A fim de ampliar a cidadania política dos indivíduos, durante a modernidade, o Estado Liberal transformou-se na República Democrática Representativa, ou no Estado Providência, e tornou-se presente na maior parte os países do mundo. Depois da Segunda Guerra, os países capitalistas passaram a adotar a socialdemocracia em sua política como garantia do capitalismo. O Estado Providência combateu a anarquia econômica liberal por meio da força do Estado. Ao invés de ser apenas um árbitro da sociedade civil, o Estado assumiu para si a economia, o encargos sociais, os serviços públicos, etc. (CHAUÍ, 2004).

O Estado Providência caracterizou-se pelas grandes plantas industriais que realizavam a atividade econômica, pela inclusão crescente dos indivíduos no mercado de trabalho através da garantia de emprego e pelos monopólios e oligopólios regulados pelo Estado. Para tanto, foi criado um fundo público para acumulação de capital, mas, também, de acumulação de dívidas. No decorrer do século XX, a produção e as finanças internacionalizaram-se e os oligopólios multinacionais passaram a não alimentar mais o fundo público nacional que, endividado, ainda precisava financiar o capital e a força de trabalho de seu país. Assim, o Estado Providência endividou-se de tal forma que entrou na crise fiscal, acabando por encolher e por privatizar-se. (id., ibid.)

O Manifesto dos Pioneiros da Educação Nova de 1932, assinado por 26 educadores brasileiros, buscava um programa de reconstrução educacional de âmbito nacional, apoiado no direito fundamental de todos e de cada um à educação. Imprimia-se, pela primeira vez na nossa história, uma função social para a educação. Com o movimento pela Escola Nova, a criança passou a ser o centro de interesse de toda ação pedagógica, principalmente por que, apesar dos 
esforços dos professores, a evasão escolar e o baixo rendimento dos alunos transformaram-se num problema.

Dessa forma, a partir da renovação pedagógica, os educadores passaram a criar estratégias onde a cultura fosse integrada à sala de aula (MARCILIO, 2005). Uma das primeiras providências que foram tomadas foi introduzir no currículo escolar a educação física e o escotismo, ação influenciada pela preocupação de outros paises com a forma física e com a saúde de seus cidadãos.

A renovação pedagógica do início do século $\mathrm{XX}$ buscou também aproximar a arte da escola, principalmente para manter os alunos na instituição escolar e transformar o ensino em algo interessante. Assim, outra providência tomada pelos educadores foi aumentar o número de bibliotecas escolares e propiciar o uso do cinema educativo, criado em 1931 por Lourenço Filho, como recurso didático. Alguns dos títulos disponíveis à época: $A$ mosca, $O$ nordeste brasileiro, $O$ milho, O algodão, entre outros (MARCILIO, 2005, 263).

Outro recurso foi o ensino de música em sala de aula. As idéias de Heitor Villa-Lobos tiveram uma imensa influência nesse setor. O ensino do desenho aplicado também passou a existir, a partir dessa época. Inicialmente encarado como um ensino técnico, em meados do século XX o ensino de arte na escola brasileira passou a ser entendido como livre expressão, principalmente depois dos estudos sobre a expressividade infantil. Nessa forma de ensino, o professor era compreendido como um mero observador, alguém que propiciava situações onde a expressividade da criança acontecia naturalmente.

Entretanto, e conforme as concepções sobre arte e sobre o ensino de arte foram se especializando mais e mais, esse ensino foi revisto. $\mathrm{Na}$ ditadura militar, a preocupação do governo de que a escola fosse um lugar produtivo deu lugar a uma educação profissionalizante e técnica. A partir da década de 80, porém, e depois da abertura política, reconheceu-se a importância de um ensino de arte significativo e que se preocupava com a influência da cultura na aprendizagem. Dessa forma, a escola passou a ser encarada como um espaço de produção de cultura e o professor passou a ser visto como um pesquisador e um instrutor das crianças nos saberes da arte. Para essa forma de se conceber a aprendizagem, os recursos didáticos são imprescindíveis, destacando-se, entre eles, as reproduções de obras de arte, os filmes cinematográficos, as músicas, as peças de teatro, as apresentações de dança, etc. (BRASIL, 1998). 
Quando aceitamos que existe uma relação intrínseca entre educação e cultura, podemos incorrer em um problema muito sério que é a valorização de determinada cultura em detrimento de outras. Felix Guattari define a palavra cultura como uma "palavra-cilada” (GUATTARI e ROLNIK, 2005, 25). Para ele, existem algumas palavras que por carregarem uma verdade implícita, nos impedem de pensar a realidade dos processos vividos.

Quando resgatamos a história do sentido da palavra cultura, percebemos que, na história, existem três sentidos para ela: o sentido da Antiguidade (cultura como valor), o sentido da Idade Média (cultura como civilização) e o sentido da modernidade (cultura como mercadoria). As culturas civilização e mercadoria de modo algum estão desvinculadas da cultura valor, ao contrário, a reafirmam, sendo que as três se complementam. Para ele, no fundo, existe apenas uma cultura, a "capitalística", etnocêntrica e logocêntrica.

Para Felix Guattari:

A cultura não é apenas uma transmissão de
informação cultural, uma transmissão de sistemas de
modelização, mas é também uma maneira de as elites
capitalisticas exporem o que eu chamaria de um mercado
geral de poder. Um poder não apenas sobre os objetos
culturais, ou sobre as possibilidades de manipulá-los e criar
algo, mas também um poder de atribuir a si os objetos
culturais como signo distintivo na relação social com os
outros. (id., ibid., 27)

Dewey também se preocupava com essa questão, como poderemos ver no texto a seguir. 


\subsection{QUINTO MOVIMENTO: A VERDADE ESTÁ NA SOCIEDADE DEMOCRÁTICA E NA LUTA DE CLASSES}

Será possível, para um sistema educativo, ser conduzido pelo estado nacional, e mesmo assim, conseguirse que não seja restringida, constringida e deturpada a perfeita finalidade social da educação? Internamente, tem-se arrostar a tendência, motivada pelas atuais condições econômicas, de se dividir a sociedade em classes, fazendo-se que algumas destas se convertam em meros instrumentos para a maior cultura de outras. Externamente a questão se relaciona com a conciliação da fidelidade nacional, do patriotismo, com a superior dedicação a coisas que unem todos os homens para fins comuns, independemente das fronteiras políticas nacionais. [...] Devem assegurar-se as facilidades escolares com tal amplitude e eficácia que, de fato, e não em nome somente, se diminuam os efeitos das desigualdades econômicas e se outorgue a todos os cidadãos igualdade de preparo para suas futuras carreiras. [...]

Tais conclusões prendem-se aos ideais genuínos da educação como a expansão das aptidões do indivíduo em um desenvolvimento progressivo orientado para fins sociais. [...]

Uma sociedade é democrática na proporção em que prepara todos os seus membros para com igualdade aquinhoarem de seus benefícios e em que assegura o maleável reajustamento de suas instituições por meio da interação das diversas formas de vida associada.

(DEWEY, 1979, 105-106) 
A matéria da educação consiste principalmente nas significações que proporcionam sentido e conteúdo à presente vida social. [...] Mantém-se o princípio em sua significação eficiente quando o educando começa com ocupações ativas de origem e utilização social e adquire uma compreensão cientifica dos materiais e leis implicados nas mesmas, mediante a assimilação, em sua experiência mais direta, das idéias e fatos comunicados por outras pessoas de experiência maior que a sua. (id., ibid, 213)

O problema da educação em uma sociedade democrática é acabar com esse dualismo [entre classes] e organizar um curso de estudos que torne a reflexão, para todos, um guia no livre exercício da atividade prática e faça que os lazeres sejam a recompensa da aceitação da responsabilidade dos serviços práticos [...] (id., ibid., 287)

De modo análogo, uma vez que a democracia é, em princípio, partidária do livre intercâmbio, da continuidade social, ela deve adotar uma teoria do conhecimento que veja neste o meio pelo qual uma experiência é proveitosa para dar direção e significação a outra. [...] Seu equivalente pedagógico é associar a aquisição dos conhecimentos nas escolas com atividades ou ocupações exercidas num ambiente de vida social. (id., ibid., 379)

Além de propor a abertura da escola à cultura e aos produtos culturais, as idéias de Dewey indicaram uma educação que fosse "igual para todos" e que colocasse "todos na escola". Para tanto, o ensino deveria ser centrado no aluno e deveria ser significativo, ou seja, a aprendizagem deveria ser baseada na experiência, no trabalho e na vida social. Só assim, o desenvolvimento social seria alcançado.

No Brasil, a preocupação com a educação da população e com o desenvolvimento social que ela propicia incentivou a criação de creches e de jardins de infância, além de medidas de alfabetização de adultos através dos supletivos e das escolas profissionalizantes. A partir do começo do século $\mathrm{XX}$, as escolas públicas e particulares proliferaram-se, num crescimento 
impressionante: o número de escolas básicas no país cresceu de algumas poucas dezenas, no final do século XIX, para mais de 200 mil escolas no começo do século XXI (MARCILIO, 2005).

Além disso, a educação à distância $(\mathrm{EAD})$, com o uso dos media, também se tornou uma realidade. Assim, além dos livros, outros media passaram a ser utilizados para educar, tais como os fascículos impressos e enviados pelo correio. O Instituto Universal Brasileiro, um marco na área da EAD, surgiu em 1941 e teve seu auge nos anos 60. O Instituto tinha como objetivo preparar pessoas alfabetizadas para o mercado de trabalho principalmente utilizando o ensino por correspondência que pressupõe a autonomia do aluno. Esse tipo de ensino se mantém até hoje.

A partir dos anos 30 o rádio também passou a ser utilizado na EAD. "Em 1935, pela primeira vez, uma cadeia de emissoras transmitia uma programação educativa” (id., ibid., 323). Apostando no sucesso dessa ação, em 1936, o MEC adquiriu sua primeira emissora de rádio, e em 1937 foi criado o Serviço de Radiodifusão Educativa do Ministério da Educação. Em 1941, foi criada a Universidade do Ar, que oferecia orientação metodológica aos professores do ensino secundário de todo o país. A partir dos anos 50, cresceu o entusiasmo com a educação popular, com a alfabetização e com a cultura. Na década de 60 havia 65 Sistemas Rádio Educativos Regionais no Brasil.

Numa ação apoiada pela United Nations Educational, Scientific and Cultural Organization (UNESCO), a EAD ganhou mais força: com o advento da televisão e sua notável expansão, as teleaulas invadiram os lares brasileiros nos mais remotos cantos do país. De 1967 a 1974, foram criados dez canais de TV Educativa no país e Projetos como o Tele-Extensão Rural, realizado na Amazônia, o Programa Nacional de Tele-educação (PRONTEL), o Movimento Brasileiro de Alfabetização (MOBRAL), o Projeto SACI (Sistema Avançado de Comunicações Interdisciplinares), o Telecurso $2^{\circ}$. Grau, da Fundação Padre Anchieta e da Rede Globo. É fato que os "professores" da EAD, muitas vezes, não são professores licenciados. São, isso sim, profissionais da comunicação.

Em 1959, a Organização das Nações Unidas (ONU) aprovou a "Declaração Universal dos Direitos da Criança", e nessa declaração, a educação passou a ser um direito das crianças brasileiras, assegurado pela assinatura do Brasil nessa declaração internacional. Em contrapartida, a antiga missão de ensinar destinada aos professores, passou a ser encarada como um dever. A partir dos anos 60, então, acontece uma verdadeira proliferação de escolas pelo Brasil. Os internatos particulares, para os filhos das famílias abastadas, também foram desaparecendo nessa 
época, dando lugar a escolas de meio-período. Com o relaxamento do rigor e da disciplina em sala de aula, diversos métodos audiovisuais foram incorporados à sala de aula, principalmente nas classes experimentais (id., ibid.).

A partir da década de 70, no Brasil, desenhou-se um quadro peculiar. Ao mesmo tempo em que a educação tecnicista imperou na educação formal, devido às orientações do governo militar, esse momento também viu nascer uma educação crítica, com claras influências marxistas e com total apoio da igreja católica. O que une essas duas concepções de educação é o dispositivo da didática. Dispositivos, para Foucault (1995), são cadeias de variáveis relacionadas entre si: os objetos visíveis, as enunciações, as forças em exercício, os sujeitos. Os dispositivos normalizam, definem e instituem as normas verdadeiras e, por isso, são normalizantes. Além disso, eles são constituintes, ou seja, eles acabam por ser constitutivos da verdade. Dessa forma, eles estão presentes tanto nas coisas "boas" como nas coisas "ruins", tanto no âmbito macrossocial quanto no microssocial.

Os mesmos dispositivos são utilizados tanto pelo poder quanto pela resistência, num encadeamento recíproco. Segundo Foucault (1995), as relações de poder e as estratégias de luta possuem atração recíproca, encadeamento indefinido e inversão perpétua, ora transformando-se em mecanismos de poder, ora transformando-se em estratégias de resistência. Dessa forma, o conceito de ideologia, criado por Marx, acaba por cair por terra, pois não é através das idéias que o poder pode ou não manipular a massa, mas, sim, através dos seus dispositivos. Por isso, também podemos entender a didática e seus recursos tanto como um dispositivo do poder quanto como uma estratégia de resistência.

Por isso, uma das ações mais efetivas realizadas com o uso dos media na educação foi feita pela Confederação Nacional dos Bispos do Brasil (CNBB). Há 40 anos, e com apoio da UNESCO e do governo federal, o Movimento de Educação de Base (MEB) realiza uma ação educacional que se estende às áreas mais subdesenvolvidas do país, com a ajuda dos media e com claro objetivo formador:

A idéias da Igreja a serviço dos pobres, inspira totalmente a linha de pensamento e ação do MEB [...] O MEB não nasceu para ser uma campanha contra o analfabetismo. Chegaremos lá. Para destruir essa 
contingência de nossa história andamos abrindo caminhos para libertação de milhares de homens e mulheres, jovens e adolescentes, pela Educação de Base [...] A sua validade está em que cada homem a quem ele ajudou a abrir os olhos descubra os seus problemas, usando sua iniciativa e andando com os próprios pés, conscientemente. (WANDERLEY, 1984, 220)

A Educação de Base tem clara influência de Paulo Freire e de sua Pedagogia Libertadora. Essa pedagogia surgiu na segunda metade do século XX e buscava o antiautoritarismo, a valorização da experiência vivida como base da relação educativa e a autogestão pedagógica. A marca da pedagogia libertadora é o ensino não-formal, fora da escola, pois a educação:

[...] é uma atividade onde professores e alunos, mediatizados pela realidade que apreendem e da qual extraem o conteúdo de aprendizagem, atingem um nível de consciência dessa mesma realidade, a fim de nela atuarem, num sentido de transformação social. (LIBÂNEO, 1985, 33)

Através dos temas geradores, que são extraídos da prática dos alunos, esse tipo de ensino proporciona uma nova relação com a experiência vivida. É uma educação de caráter essencialmente político e de aproximação crítica da realidade.

Também inspirado nas idéias de Paulo Freire, desde a década de 80 o professor e jornalista Ismar de Oliveira Soares, vem desenvolvendo a Educomunicação. A educomunicação tem a educação como fim de um processo dialógico e horizontalizado como um pressuposto de uma "comunicação real". Dessa forma, orienta o uso dos meios de comunicação no ambiente escolar como ferramenta didática e como meio de produção cultural dos alunos, visando à democratização do ambiente escolar, enfatizando o caráter social e comunitário da educação, reafirmando a escola como espaço de interação e repensando a hierarquia das relações sociais, tais como a relação professor-aluno e a relação escola-aluno, além de valorizar a cultura oralvisual em relação à cultura escrita. 
Ao estimular o uso de tecnologias de produção de discurso na escola que não apenas a escrita, a educomunicação possibilita ao aluno se transformar em sujeito da fala, aumentando sua capacidade de expressão e colocando-o diante de seus direitos, além de estimulá-lo a exercitar sua autonomia. A ação da educomunicação busca práticas que incorporem as tecnologias de comunicação e de informação no processo educativo, tanto em ambientes escolares formais quanto informais, os Ecossistemas Comunicativos (tais como escolas, centros culturais, emissoras de TV e rádio educativo, centros produtores de materiais educativos analógicos e digitais, centros coordenadores de educação a distância ou "e-learning", e outros), reconfigurando o "educar" dentro do contexto delineado pela contemporaneidade, visando, principalmente, a formação de comunidades (SOARES, 2004).

A Educomunicação insere-se num momento de autocrítica feito pelos educadores brasileiros. Libâneo (1985) nos conta que foi por volta de 1980 que começaram a se desenvolver no Brasil

[...] estudos e pesquisas que, sem descuidar da consideração dos determinantes estruturais, procuram determinar a influência da própria escola na marginalização social das camadas populares e, em decorrência, propor a escolarização formal na escola pública dentro de uma perspectiva de uma nova qualidade de ensino (id., ibid., 61)

Assim, desde o final do século XX, um grupo de educadores vem tentando atuar dentro do se chamou Pedagogia Crítica, "por acreditar na possibilidade de explorar os espaços disponíveis pelas contradições da sociedade” (id., ibid., 62). Podemos afirmar que o resultado desses estudos foram os Parâmetros Curriculares Nacionais (PCNs) e a nova Lei De Diretrizes Básicas Da Educação de 96 (LDB), que têm como "princípio básico que a educação tem por finalidade o pleno desenvolvimento do educando, seu preparo para o exercício da cidadania e sua qualificação para o trabalho” (MARCILIO, 2005, 347).

Outra orientação da LDB de 96 foi a indicação do uso de novas metodologias para a EAD, como uma opção àqueles que por motivos diversos não podem seguir a escola formal ou 
não tiveram sucesso nesse tipo de ensino. No site do $\mathrm{MEC}^{12}$, podemos verificar a situação da Educação à distância no Brasil, em 2005:

52.039 escolas públicas com 308.539 computadores;

23.719 escolas públicas acessam Internet;

10.227 escolas públicas com mais de 10 computadores;

83.532 escolas públicas com 167.712 televisões;

75.172 escolas públicas com 129.276 videocassetes;

52.302 escolas públicas com 58.522 antenas parabólicas;

47.732 escolas públicas com KIT completo;

25.942 escolas públicas com TV Escola;

27.615 escolas públicas com Sala TV/Vídeo;

5.000 escolas públicas beneficiadas com o ProInfo.

E tudo leva a crer que esses números só tendem a crescer. Além disso, o governo mantém diversos programas que incentivam o aprendizado via tecnologias de comunicação, tanto para os alunos, quanto para os professores e para os gestores da escola pública. Entre eles destacamos a TV Escola, a Rádio Escola, o PROINFO (Programa educacional que promove o uso da Telemática na educação), a Rede internacional Virtual de Educação (RIVED), o PAPED (Programa de apoio às pesquisas em educação à distancia em convênio com a CAPES), o Webeduc (site educacional em cooperação com a França) e o PROFORMAÇÃO (formação de professores usando a Internet e a educação à distância).

Além disso, e também a partir da década de 80, devido às grandes mudanças ocorridas na economia, na cultura e no mundo do trabalho, a sociedade passou a valorizar os processos de aprendizagem em grupo e as diversas formas de cultura que articulam as ações dos indivíduos. Assim, a educação exercida fora da escola formal ganhou status e importância. Com o surgimento das Organizações Não-Governamentais (ONGs) e a participação mais ativa das agências e organismos internacionais, como a ONU e a UNESCO, instalou-se a urgência de uma “educação para outras dimensões além da escola” (GOHN, 1999, 92), a educação não-formal.

As ONGs, como estimuladoras do trabalho voluntário e de revalorização das culturas locais, resgataram formas de conhecimento antes ignoradas, e desenvolveram know-how em 
metodologias, estratégias e programas de ação especialmente para comunidades excluídas como as indígenas, rurais e a população urbana de baixa renda. Nesse ambiente não-formal, muitas vezes os "professores" não possuem habilitação. São técnicos especializados em diversas produções, amadores, pessoas da comunidade que fazem trabalho voluntário, artistas, universitários, psicólogos, arte-educadores e alfabetizadores.

Em nossos dias, tanto a educação não-formal quanto a formal vêm cumprindo a função de capacitação profissional. Entretanto, isso não garante a recolocação profissional do cidadão, pois o problema do trabalho nos dias atuais é de âmbito econômico e político, o neoliberalismo, e não de formação individual do trabalhador (id., ibid.). A doutrina Neoliberal é contra a participação do Estado como regulador das atividades sociais e como regulador das atividades do mercado. Essa doutrina, nascida em meados dos anos 40, ressurgiu com força na década de 70 quando o capitalismo entrou em crise econômica pela primeira vez (CHAUÍ, 2004). Na prática, o que estamos presenciando desde o final do século XX é a perda do poder do Estado para as empresas multinacionais e o surgimento de um novo capitalismo que caracteriza-se pelo desemprego estrutural, pelo poder do capital financeiro, pela terceirização, pela força produtiva da tecnologia, pela privatização dos serviços públicos, pela transnacionalização da economia e pela desigualdade social radical (id., ibid.).

Portanto, podemos afirmar que estamos no limiar de uma nova era da História, ou seja, estamos vivendo um momento de ruptura que vem sendo construído no percurso da modernidade e que se potencializou no final do século XX. Esse momento, que é chamado por alguns de pósmodernidade (BAUMAN, 1998; LYOTARD, 1998), por outros de modernidade tardia (GIDDENS, 1991) ou mesmo modernidade líquida (BAUMAN, 2001), vem constituindo o encerramento do sistema social da modernidade e o surgimento de um novo sistema social, a sociedade de consumo ou sociedade de informação.

Em nossos dias, assistimos a uma verdadeira revolução na educação com o incremento das novas tecnologias de informação na sala de aula e na EAD, tanto em ambientes de educação formal quanto em ambientes informais de ensino. Com a possibilidade de receber e enviar textos, imagens e sons instantaneamente - ou seja, com uma enorme capacidade interativa - a Internet tornou-se o medium ideal para a formação de comunidades e de grupos virtuais com a finalidade de pesquisa e aprendizado. Pode-se participar de aulas virtuais como se estivesse no ambiente 
escolar, receber orientações dos professores por e-mail ou por voz e imagem, 24 horas por dia, participar de fóruns e chats, consultar acervos de bibliotecas, receber boletins informativos, etc.

A tendência, como todos estamos constatando já há algum tempo, é de que a tecnologia de informação substitua o professor porque ela funciona extremamente bem como transmissora de conteúdos, e por que não? Funciona também como uma mediadora entre os saberes e os aprendizes. Em última instância, o mediador busca significados e compartilha-os com seus alunos, orientando o processo de construção de conhecimento do aprendiz. Para tanto, desencadeia nele a necessidade de elaborar boas respostas a suas boas perguntas. $\mathrm{O}$ professor mediador desafia, desperta o interesse do aprendiz. O professor mediador organiza a relação psicopedagógica através de um método clínico, de perguntas pontuais. O fracasso nesse processo pode estar associado à pouca clareza do significado do desafio proposto pelo professor. Caso o ele não tenha claro o significado daquilo que quer ensinar, a mediação não ocorre. A cada dia, a tecnologia da informação adquire mais e mais capacidade de armazenamento e de processamento de dados. O ambiente virtual está cada vez mais atraente e desafiador, e possui recursos audiovisuais dinâmicos e interessantes que emulam o homem de forma extremamente competente. Dessa forma, por que a tecnologia de informação não poderia substituir o professor mediador?

Entretanto, a Internet ainda segue um modelo que compreende um modo de aprender baseado em formas prontas, com um "menu" variadíssimo, porém, pré-determinado. E, acima de tudo, passível de criticas quanto ao seu conteúdo. Uma das maiores preocupações dos educadores, e dos pais, em relação à Internet, é que ela permite, principalmente às crianças, o acesso a conteúdos inadequados e ruins, baseando seu juízo no fato de que às crianças só podemos fornecer verdades e conhecimentos que elas sejam capazes de compreender e que sejam bons para elas. Ainda o modelo de educação de Comenius... 


\section{1․8. CONCLUSÃO DO $1^{\circ}$. CAPÍTULO - O SUJEITO DIDATA E A LINGUAGEM REPRESENTACIONAL}

Os discursos da Bíblia, da Didactica Magna de Comenius, d'O Emilio de Rousseau e do Democracia e Educação de Dewey, a despeito de suas especificidades em relação ao sujeito que aprende, ao conhecimento e à interação professor-aluno-conhecimento, articulam-se no eixo da construção do sujeito que ensina como alguém que deve comunicar, através da razão e de seus princípios, mensagens claras que levem o aprendiz a desenvolver sua inteligência e a alcançar o conhecimento verdadeiro. Para tanto, todos os discursos orientam o uso dos mais diversos meios de comunicação como recursos didáticos imprescindíveis à boa educação. Além disso, esses meios devem utilizar as mais diversas linguagens. A idéia geral sobre linguagem que permeia todos os discursos recortados nesse capítulo é a idéia de que a linguagem trabalha com signos que servem para representar e significar as coisas do mundo e as idéias. Esses signos possuem um código comum de representação que deve ser conhecido tanto pelo professor quanto pelo aluno. Caso o professor e o aluno não possuam o mesmo código de representação, caso os signos utilizados pelo professor não signifiquem aquilo que deve ser ensinado e aprendido e caso a resposta do aluno não seja adequada à significação comunicada a ele pelo professor, a comunicação não se dá e, conseqüentemente, o aprendizado também não.

Conforme a teoria da Informação, quando a comunicação não acontece, o ruído se dá. Podemos, então, afirmar que para todos os discursos apresentados nesse capítulo, o ruído é a causa da falha na comunicação professor-aluno e uma das principais causas do fracasso no processo de ensino e de aprendizado. Dessa forma, apesar de parecerem contraditórios, os discursos apresentados nesse capítulo possuem um aspecto em comum: a concepção da linguagem como representação, a concepção de comunicação como transmissão de mensagens significativas e a concepção de ruído como uma falha na comunicação e como fracasso no processo de ensino e de aprendizado. De onde vêm essas idéias? 
Para referir-se à palavra e à linguagem, os gregos possuíam duas palavras: mythos e lógos. O pensamento mitológico é uma das formas de organizar a realidade, porque ele dá às coisas um sentido analógico e metafórico. Ele cria símbolos, imagens com múltiplos e simultâneos sentidos.

O pensamento lógico ou conceitual opera de maneira diferente: ele opera por método e cria conceitos. O pensamento lógico ou racional é uma outra forma de organização do real. A lógica vem da palavra lógos, que significa "linguagem-discurso e pensamento-conhecimento" (CHAUÍ, 2004, 104). As idéias ou conceitos criados pelo pensamento lógico não são imagens ou símbolos, são uma descrição e uma significação. As idéias e os conceitos são a compreensão intelectual que fazemos das coisas, são o resultado de uma análise ou de uma síntese de dados reais, a partir da experiência. Além disso, partem de juízos e de raciocínios que organizam a experiência e a tornam compreensível do ponto de vista lógico. Esses juízos e raciocínios buscam causas universais e necessárias pelas quais uma realidade é tal como é, e não como nos parece. $\mathrm{O}$ juízo e o raciocínio investigam e estudam a diferença entre as vivências subjetivas e a estrutura objetiva do pensamento em geral, e para tanto utilizam métodos de avaliação e de generalização dos conhecimentos adquiridos, regras de ordenamento e sistematização dos procedimentos e resultados. Assim, regulam os novos conhecimentos de forma que só se juntarão aos anteriores a partir de regras pré-estabelecidas. Para nós, o conhecimento intelectivo propõe conceitos e representa coisas, usando-se da linguagem para significar o que é dado pelos sentidos e para comunicar esses conceitos aos outros (id., ibid.).

Para o senso comum, como numa fita de Moebius, inteligência e pensamento/linguagem são aquilo que configura o conhecimento:

O conhecimento inteligente apreende o sentido das palavras, interpreta-o, inventa novos sentidos para palavras antigas ou cria novas palavras para novos sentidos. $\mathrm{O}$ movimento do conhecer é, pois, um movimento cujo corpo é a linguagem. Graças a ela, compartilhamos com outros os nossos conhecimentos e recebemos de outros os conhecimentos. (id., ibid., 161) 
A principal conseqüência na educação desse modo de pensar é a necessidade que se criou de se ensinar linguagem para as crianças a fim de que elas sejam detentoras do código comum de representação usado para a comunicação. Isso é tão enraizado em nossa cultura que nunca questionamos essa necessidade, que se tornou, para nós, algo natural. Entretanto, ensinar linguagem não é algo natural, e sim, algo construído histórica e socialmente, algo que faz parte da cultura, entendida como aquilo que cria civilizações, valora determinadas produções e mantém um mercado de produtos culturais e os jogos do poder (GUATTARI; ROLNIK, 2005).

A segunda conseqüência do uso da linguagem representacional na educação é a valorização da linguagem lógica em detrimento da linguagem mitológica. $O$ uso da linguagem lógica na educação estruturou o modo como professor e aluno se comunicam em sala de aula, o modo como os saberes são organizados no currículo e o valor que damos ao significado dos conceitos e idéias. Esse valor está presente principalmente na forma como avaliamos o aprendizado de nossos alunos. Em geral, o que se avalia neles é se o significado dos conceitos e idéias transmitidos ou mediados pelo professor foi compreendido e assimilado. Em outras palavras, a significação é o conhecimento para nós.

Em nossa tradição filosófica, o conhecimento está ligado à razão e seus princípios. A definição que fazemos de nós mesmos é de que somos seres racionais. A razão obedece a determinadas regras que nem chegam à nossa consciência quando pensamos. O conhecimento racional segue determinados princípios que são opostos ao conhecimento ilusório (costumes, preconceitos, aparências), às emoções e sentimentos (paixões cegas, caóticas, desordenadas), à crença religiosa (a revelação divina) e ao êxtase místico (inconsciência). E é por isso que uma das primeiras questões filosóficas foi definir a razão.

Os primeiros filósofos indagaram-se se o pensamento lógico obedece ou não a regras, normas, princípios e critérios para seu uso. Os gregos Heráclito e Parmênides encontraram respostas opostas para essa pergunta. Heráclito concluiu que o mundo é um fluxo perpétuo onde nada permanece idêntico a si mesmo, mas tudo se transforma em seu contrário. Apesar de nossa experiência sensorial perceber o mundo como estável e permanente, nosso pensamento sabe que nada permanece, tudo se transforma em seu contrário. Por isso, para Heráclito, a verdade e o lógos são a mudança das coisas nos seus contrários, ou seja, a contradição é a lei racional da realidade. Parmênides, em contrapartida, afirmou que o lógos é sempre idêntico a si mesmo, sem contradições, e a mudança é o não-ser, o nada, o impensável e o indizível. Para ele, o pensamento 
e a linguagem verdadeira só são possíveis se as coisas que pensamos e dizemos guardarem identidade e permanência. Para Parmênides, a verdade e o lógos são a identidade do ser imutável, oposto à aparência sensível da luta dos contrários, ou seja, a identidade é a lei racional da realidade (id., ibid.).

Mais tarde, Platão, ao pensar sobre isso, dividiu o mundo em dois tipos: o mundo sensível, o mundo do devir, o mundo dos seres corporais que conhecemos por meio de nossas sensações, percepções e opiniões, o mundo das transformações e das contradições, o mundo dos simulacros, e o mundo inteligível, o mundo das essências imutáveis, o mundo verdadeiro onde não existem transformações nem contradições, o mundo das cópias imperfeitas daquilo que é perfeito, o mundo das Idéias. Para ele, o mundo sensível é heraclitiano e o mundo inteligível, parmenidiano. Então, como passar de um mundo ao outro? Através da dialética, do diálogo, do discurso compartilhado onde opiniões opostas possam ser superadas para se chegar a uma Idéia que é a mesma para todos que buscam a verdade. A dialética é um procedimento intelectual e lingüístico que determina o que é verdadeiro ou falso, até chegar à identidade da essência ou da idéia imutável, aquilo que é o mesmo para todas as inteligências (id., ibid.). A dialética de Platão é a retórica filosófica, ou seja, um tipo de retórica que segue um determinado método de perguntas e respostas.

Aristóteles, depois de Platão, uniu esses dois mundos e não aceitou que a mudança ou o devir fosse ilusão. Há seres em que a essência é imutável e seres em que a essência é mutável. Para ele, a transformação não é contradição, como pensou Heráclito. Ela é a maneira pela qual as coisas realizam todas as potencialidades contidas em sua essência, essência essa que o pensamento pode conhecer. Da mesma forma, o pensamento também pode conhecer a essência das coisas imutáveis. Por isso, para ele, cabe à filosofia conhecer os dois tipos de seres, classificá-los, julgá-los e organizá-los. Para tanto, ao invés da dialética, ele propôs a um conjunto de procedimentos de demonstração e prova como método. Esse método foi chamado por Aristóteles de analítica. Seu ponto de partida não são opiniões contrárias, mas sim princípios, regras e leis necessárias e universais do pensamento. A analítica de Aristóteles pressupõe o uso do raciocínio e da inteligência, e não das emoções ou dos sentimentos, e foi eleita pelo filósofo como o tipo de discurso que mais se aproxima do conhecimento inteligível. O filósofo define mais dois outros tipos de discurso: a poética, que não pode ser usada para ensinar, porque não 
chega ao conhecimento inteligível, e a retórica, usada para a persuasão e para o ensino, não apenas porque persuade, mas porque é bela, é de uma beleza verdadeira e justa (id., ibid.).

A atividade racional possui duas modalidades: a intuição e o raciocínio. De um modo geral, entendemos a intuição como uma compreensão global e completa de uma verdade, de um objeto ou de um fato. De uma só vez, a razão capta todas as relações que constituem a realidade e, também, a verdade. O raciocínio trabalha de forma diferente, ele é o processo do conhecimento. O conhecimento pode se dar, em algum momento do processo, através da intuição. Mas, para nós, o conhecimento racional é mais importante porque ele trabalha com provas e demonstrações, e trabalha com o discurso, principalmente, com o discurso que generaliza e universaliza. O conhecimento racional cria teorias, discursos que ganham o status de verdade (id., ibid.).

Há que se perguntar, então, como adquirimos a razão ou o conhecimento racional. A filosofia se divide, em relação a isso: existem correntes filosóficas que aceitam que a razão é inata, existem correntes que aceitam que a razão é adquirida. Essa é a questão principal que moveu mudanças no modo como encaramos o conhecimento, porque ela influi diretamente no modo como organizamos os saberes (aquilo que aceitamos como verdades) e no modo como os transmitimos de geração a geração.

Uma das soluções para esse impasse que mais marcaram a história do pensamento ocidental foi desenvolvida por Immanuel Kant, no século XVIII. A partir de suas idéias, nasceu a divisão entre as ciências empíricas e a filosofia transcendental. Para ele, o sujeito do conhecimento é uma estrutura universal e idêntica para todos os seres humanos em todos os tempos e lugares, ou seja, o sujeito do conhecimento é a própria razão, e a realidade acaba por ser entendida como estruturada pelas idéias do sujeito. Foi a partir das idéias de Kant que as ciências humanas herdaram a tarefa da metafísica de tentar alcançar a realidade e os fenômenos dessa realidade, mas sob as condições gerais universais e necessárias da objetividade e da razão. Por isso a metafísica kantiana também é chamada de idealista, porque ela vai das idéias produzidas pelo sujeito em direção às coisas. E é também chamada de filosofia da Consciência, pois dá prioridade para o sujeito do conhecimento ou à consciência de si reflexiva. Por isso, para nós, que fazemos parte da civilização ocidental moderna, o conhecimento tem como centro a figura do sujeito do conhecimento, na qualidade de consciência de si reflexiva ou atividade permanente racional que conhece a si mesma (id., ibid.). 
Para o pensamento moderno, numa sala de aula os sujeitos encontram-se em busca da ressignificação dos mais variados conceitos sobre os objetos do conhecimento, conceitos esses que vêm sendo acumulados pela humanidade. Esses conceitos, suas qualidades e suas características, são aquilo que costumamos chamar de saber. O conjunto dos métodos para ensinar e aprender os saberes tem como objetivo principal o aprendizado e a compreensão dos conceitos já criados e habilitar os aprendizes a usar a linguagem como representação. Ao aprender, as pessoas incrementam sua inteligência ou a faculdade que possuem de conhecer, de compreender e de representar suas idéias. As diversas didáticas usadas para ensinar utilizam linguagens e conjuntos de signos para transmitir ou comunicar os saberes aos alunos. Através dos recursos didáticos, comunicações úteis e objetos culturais, as pessoas presentes numa sala de aula recebem informações necessárias e adequadas.

Assim, segundo a tradição filosófica clássica, num encontro pedagógico ideal, busca-se a transmissão de informações através de um diálogo pedagógico. Nesse encontro ideal, utiliza-se uma Didática Geral, uma didática que se aplica a qualquer área do saber, e diversas didáticas específicas, utilizadas conforme a disciplina. Num encontro pedagógico ideal, ao aprender, as pessoas atingem uma posição superior na hierarquia do saber.

No começo do século XX, devido ao surgimento da lingüística, outros aspectos passaram a ser incorporados ao encontro pedagógico ideal. A lingüística compreende a linguagem por duas dimensões: a fala e a língua. Para os lingüistas, a língua possui um caráter social. A principal conseqüência desse modo de pensar é a de que o ensino da língua deve ser levado a todos, sem distinção. Levar saber ao povo significa capacitar todos na linguagem denotativa, clara, científica, matemática e lógica. Ser capaz de usar corretamente os códigos da língua abre as portas aos saberes acumulados na história da humanidade e dessa forma, toda a sociedade acaba por se desenvolver.

A segunda conseqüência é que o desenvolvimento da inteligência leve à critica da significação. No caso da educação, a crítica cai sobre a pragmática, sobre o fazer escolar. Em nossos dias, já é lugar comum a busca por um tipo de professor, o professor crítico, ou seja, o professor que critica sobre sua prática a fim de torná-la melhor, à frente de seu tempo. Através da crítica à prática e da proposta de novas ações, ou seja, através da aplicação de suas idéias, o professor renova sua prática. Entretanto, muitas vezes, o professor acaba por ver-se num beco 
sem saída. Invariavelmente, a crítica recai sobre as instâncias maiores que ele, sobre as contradições presentes na sociedade, e uma enorme sensação de impotência o abate.

Em geral, e também devido à nossa tradição filosófica, a solução encontrada para o problema da educação é buscar técnicas e tecnologias que, aliadas ao trabalho pedagógico, garantam a assimilação dos significados por parte do aluno. Prova disso é o enorme investimento que o governo e as empresas vêm fazendo para equipar as escolas com tecnologias de ponta em comunicação e informação. Entretanto, e apesar de todo o apoio do governo e das empresas, essas ações ainda não estão efetivando uma melhoria na qualidade do ensino brasileiro, conforme as avaliações da UNESCO.

Marcílio (2005) nos fala que uma das principais questões da educação contemporânea no Brasil é o fracasso escolar. E uma das maiores expressões desse fracasso está na repetência dos alunos. O Brasil foi considerado o campeão mundial em repetência, numa pesquisa realizada pela UNESCO, em 1997. Entretanto esses números estão caindo nos últimos anos, principalmente por causa do Regime de Progressão Continuada, que junto com o Sistema de Ciclos constituiu-se a grande polêmica dos anos 90 em relação à educação. O regime de Progressão Continuada, que utiliza o sistema de avaliação continua e cumulativa, permite constatar a necessidade de atividades de reforço e recuperação. Caso algum aluno não consiga repor suas lacunas de aprendizagem, fica retido um ano para essa recuperação. Segundo o censo educacional de 2000, 23\% das escolas brasileiras haviam adotado esse sistema de avaliação. Entretanto, em 2001, o Brasil ainda exibia um ensino básico caracterizado pela distorção idade/série. No ensino fundamental, 39\% dos alunos tinham idade inadequada para a série que cursavam e no ensino médio, $53 \%$ (id., ibid.).

Existem inúmeras explicações para justificar esse fracasso. Para mim, o que mais influencia o fracasso escolar é a própria idéia que temos de erro. Aquilo que o senso comum entende como fracasso está vinculado a um paradigma que nos acompanha desde que Platão afirmou que o mundo do simulacro, dos devires, era o mundo do falso, do não-controle, do erro. A história da educação nos mostra que as auto-avaliações feitas por quem ensina e por quem gere as instituições escolares nunca são satisfatórias, sempre são relativas a algum aspecto que "falta", que precisa ser buscado. Uma eterna insatisfação. Uma eterna frustração.

Contudo, nessa dissertação, eu não defendo a idéia de que o erro ensina. Não é esse o meu objetivo. Por isso, no próximo capítulo, busco na filosofia de Deleuze e Guattari uma outra forma 
de pensar o modo como se ensina, se aprende e se compreende o saber. Por essa via, o erro, como o inverso do acerto, não existe. Para a filosofia deleuzeana, o que existe são sempre acontecimentos, singularidades. O que existe é a errância fazendo parte de um processo de transformação do saber. Esse modo de pensar propicia, entre outros benefícios, um realismo em relação à vida que a nossa civilização perdeu. O século XX foi o palco de um niilismo extremado que culminou na morte de inúmeros valores importantes para a vida em sociedade. Podemos mesmo afirmar que vivemos um momento de luto pela perda de tradições e rituais que por muitos séculos nos definiram e nos identificaram. Por um lado, isso é triste. Por outro, permite a abertura de nosso pensamento a novas formas de encarar a vida.

Entretanto, a filosofia deleuzeana não é uma saída para os problemas atuais. Ela é, antes de tudo, uma injeção de entusiasmo e de alegria num momento em que o desânimo e o pessimismo tomam conta de todas as críticas. Ela nos leva a um tipo de otimismo que não consiste em pensar de forma positiva, racionalista, sempre buscando algo melhor a ser alcançado, como uma forma constante de auto-engano. De uma forma mais realista e pragmática, a filosofia deleuzeana reconhece que tudo repousa sobre uma base frágil, fugidia, contingente, e, assim, tudo pode mudar, tudo pode ser possível, se distanciando, dessa forma, de todo e qualquer tipo de niilismo. $\mathrm{O}$ pensamento deleuzeano distingue três tipos de niilismo: negativo, reativo e passivo. O primeiro e o segundo são associados ao cristianismo, o terceiro ao racionalismo científico moderno. O negativo consiste em negar a vida em prol de um mundo superior, encarnado pela figura de Deus. Com sua morte, no entanto, surge um novo tipo de niilismo ateu, onde o homem torna-se o centro do conhecimento, e novos princípios como o progresso, a verdade científica, o aperfeiçoamento, a lógica utilitária e a felicidade tomam o lugar dos antigos valores transcendentes. A ciência moderna destrói a crença em um "outro mundo", mas, ao mesmo tempo, gera uma ausência de valores que nada mais é do que uma outra forma de niilismo, porque prega o momento presente como o único que existe, valorizando o individualismo, o nada, o ceticismo.

A filosofia de Deleuze e Guattari estimula a singularização e vai contra o individualismo resultante do niilismo. Uma singularidade é sempre um conjunto de coisas-seres-signos-idéias, é sempre um bloco. Por essa via, coloca em xeque a nossa capacidade de acreditar em fazer juntos, em partilhar. A filosofia deleuzeana estimula uma individualidade sabedora de sua dependência com os outros e com o mundo, e nos faz sentir um genuíno amor pela Vida. 


\section{$2^{\circ}$. CAPÍTULO - A CABEÇA DA MEDUSA}

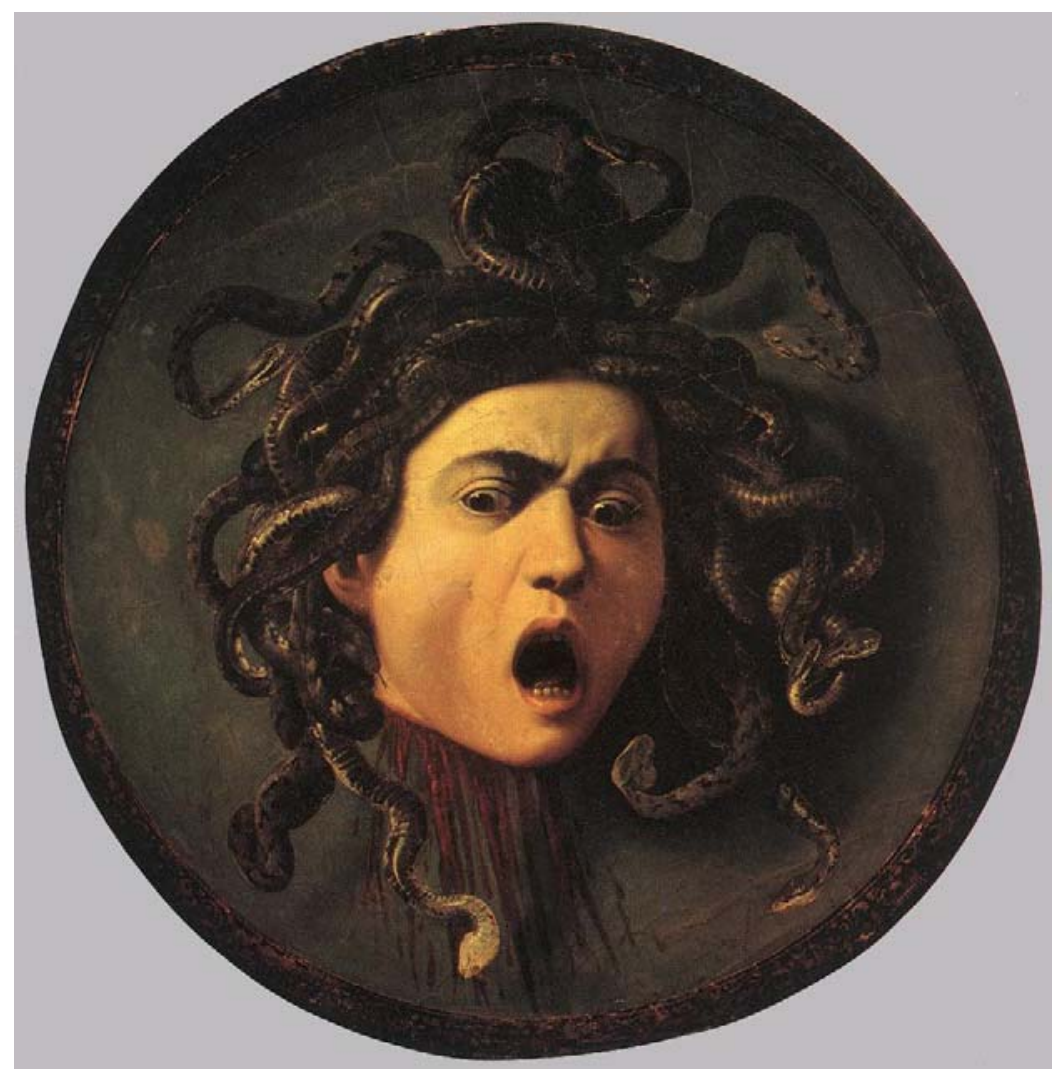

Medusa

Óleo sobre tela

Caravaggio (1571 - 1610) 


\subsection{A REALIDADE}

Na mitologia grega, Medusa, uma das divindades primordiais, era uma das três irmãs górgonas. Filhas das divindades marinhas Fórcis e Ceto, elas representavam a sabedoria feminina soberana, os mistérios femininos, todas as forças da Grande Deusa primordial, os ciclos do tempo, os ciclos da natureza como vida, morte e renascimento. Elas representavam, também, a criatividade e a destruição universais em transformação eterna, eram guardiãs dos umbrais e mediatrizes entre os reinos do Céu, da Terra e do Mundo Inferior. Elas destruíam para construir, alcançando assim o equilíbrio. Elas purificavam e curavam.

Originalmente, as três górgonas tinham rostos muito belos e corpos bem delineados, além de apresentarem graciosas asas douradas arqueadas por sobre os ombros. Entretanto, ao fazer amor com Poseidon, o deus do Mar, em um dos santuários de Palas Atena, Medusa provocou a ira da deusa máxima dos gregos, a deusa que enaltecia a serenidade da sabedoria grega. Enfurecida, Atena tornou Medusa mortal e a transformou, e às suas irmãs, em feias megeras, as "Repugnantes". O aspecto das górgonas passou a ser assustador: presas de javali, cabelos constituídos de serpentes vivas, mãos de bronze e asas de ouro. Seu olhar, de tão penetrante, transformava suas vítimas em pedra. Medusa era a mais feia e petrificadora das três.

Temidas pelos homens e pelos deuses, as górgonas viviam juntas no além-mar e seu santuário formava fronteira com o reino da Noite. Elas viveram ali por milhares de anos até que um dia, Perseu, herói fundador da cidade de Micenas, recebeu do rei Polidectes a missão suicida de matar Medusa. O rei queria que Perseu se afastasse de sua mãe, Dânae.

Entretanto, Perseu, que era filho de Zeus, recebeu o auxílio dos deuses, principalmente de Palas Atena e de Hermes, o mensageiro dos deuses, o deus da comunicação e do comércio, inventor da escrita, protetor dos viajantes, dos atletas, dos oradores, dos filósofos, dos intelectuais, e, também, dos ladrões. Atenas segurou seu escudo de bronze de modo que Perseu pôde ver a imagem da górgona ao invés de olhar diretamente para sua terrível face. Assim, com a espada que ganhou de Hermes, o herói conseguiu decapitar Medusa. 
A cabeça da Medusa, depois de sua morte, passou a figurar no escudo da deusa Minerva e servia-lhe como defesa. Entretanto, algumas histórias relatam que ela aparecia, de repente, no meio do peito de Palas Atena ${ }^{13}$.

A meu ver, o mito da Medusa ilustra, de forma exemplar, o modo como nós, seres da civilização ocidental, entendemos a inteligência, o pensamento, a linguagem, o conhecimento e conseqüentemente, a educação. Em linhas gerais, para nós, a inteligência é a capacidade que temos de encontrar soluções práticas para os problemas e a capacidade de antecipar situações. Além disso, a inteligência também é teórica e abstrata, ela é o exercício do pensamento e, por isso, é inseparável da linguagem.

Para o senso comum, nós alcançamos o conhecimento porque usamos a consciência e a razão. Além disso, para o senso comum, a verdade está presente nas teorias racionais e universais criadas pelo sujeito do conhecimento. Essas verdades devem estar ligadas ao Bem, a partir de modelos de julgamento. A isso, chamamos bom senso. Além disso, para que essas teorias ganhem o status de verdade, precisam ser comunicadas, precisam ser transmitidas de pessoa a pessoa através da linguagem, precisam ser ensinadas e comunicadas, ou seja, precisam se tornar senso comum. Para nós, a verdade precisa ser comunicável, tem de se tornar comum por meio da linguagem representacional e da Doxa (o bom senso e o senso comum). Segundo nossa tradição lógica, devemos nos prender "ao conjunto de coordenadas comuns que coincidam com a opinião" (BIANCO, 2005, 1298). Essas coordenadas comuns são aquilo que estrutura a comunicação e a educação: a linguagem representacional e a Doxa.

Em nossa prática diária, seja como professores na instituição escolar, seja como "mestres" na sala de aula social, buscamos agir conforme a Doxa e, assim, agimos como o herói Perseu: com a ajuda do pensamento lógico e racional - o escudo de Atena - usamos a comunicação - a espada de Hermes - para destruir o devir e as transformações - a cabeça da Medusa. Para nós, é assim que se ensina o saber e é assim que levamos nossos alunos ao conhecimento. E quando isso não acontece, nos sentimos fracassados e frustrados.

Entretanto, numa sala de aula real sempre existiram trocas inesperadas. É no espaço real da sala de aula que as pessoas efetivamente esbarram-se umas nas outras, olham-se, tocam-se, cheiram-se. É no espaço da sala de aula que, muitas vezes, acontece o prazer, a alegria, a euforia, 
a frustração, a atração, a sedução, a incompetência, a tristeza, a raiva, a repulsa, a agressão, o desinteresse, o silêncio e mesmo a total apatia. É no espaço da sala de aula que o professor fracassa, é no espaço da sala de aula que o professor perde o controle sobre o processo de ensinar. E é nesse emaranhado de afeições e percepções que o objetivo primeiro de um encontro pedagógico ideal, a busca pelo significado e pela interpretação, foge pelo ralo, escoa pelas frestas das portas e das janelas, escapa pelo ar, traça uma linha rizomática e se perde no non-sense da busca pelo sentido. Para quê mesmo que estamos aqui?

E como no mito, de vez em quando, de repente, a cabeça da Medusa aparece no meio do peito de Atenas, a deusa da sabedoria. Nesses momentos, enxergamos aquilo de mistério que faz com que a ressignificação não aconteça. Aquilo de mistério que faz com que, mesmo utilizando todos os recursos didáticos disponíveis, a transmissão de informações não aconteça sem ruído. $\mathrm{E}$ também aquilo de mistério que cria novas vias de comunicação, novos fluxos, novas ligações sinestésicas.

Por isso, nesse capítulo da dissertação, busquei traçar um diagrama que nos permite entender o ensino como um fenômeno complexo, com uma causalidade complexa que leva em conta o constante relacionamento do fenômeno do ensino com os demais fenômenos e com suas próprias partes, constituindo assim, um sistema que se autoproduz. 


\section{O PARADOXO}

Em 1969, Gilles Deleuze já havia publicado dois livros importantes, "A lógica do sentido" e "Diferença e repetição", quando se uniu a Felix Guattari, filósofo francês que, depois de abandonar a psicanálise lacaniana e o modelo revolucionário leninista, passou a pesquisar o desejo na vida cotidiana. Gilles Deleuze e Félix Guattari, assim como Foucault, buscaram uma filosofia que fosse nova, mas que também retomasse o já pensado. Eles faziam parte de uma linha filosófica que tem como expoentes Espinosa, Bergson e Nietzsche, uma filosofia que se interessa pela diversidade, pluralidade e singularidade, ao invés de uma filosofia baseada numa Idéia universal e numa totalidade que contém partes singulares. A filosofia de Deleuze e Guattari se interessa menos pelas semelhanças e identidades e muito mais pela singularidade e particularidade, por isso sua filosofia também é chamada de Filosofia da Diferença.

Essa filosofia faz parte de uma linha que surgiu na França no final dos anos 60 e que buscava trazer a filosofia para mais perto do presente. "A filosofia de Deleuze é uma constante atenção ao mundo e ao tempo presente, a busca dos pequenos detalhes, que são o que realmente importa" (GALLO, 2005, 36). Ainda que considerando a história como imprescindível à filosofia, Deleuze e Guattari buscaram criar uma filosofia não reflexiva, ou seja, que pense além do que é dado como acontecido.

\footnotetext{
A história da filosofia não é uma disciplina particularmente reflexiva. É antes como uma arte de retrato em pintura. São retratos mentais, conceituais. Como em pintura, é preciso fazer semelhante, mas por meios que não sejam semelhantes, por meios diferentes: a semelhança deve ser produzida, e não ser um meio para reproduzir (aí, nos contentaríamos em redizer o que o filósofo disse). Os filósofos trazem novos conceitos, eles os expõem, mas não dizem, pelo menos não completamente, a quais problemas
} 
eles respondem. Por exemplo, Hume expõe um conceito original de crença, mas não diz por que nem como o problema do conhecimento se coloca de tal forma que o conhecimento seja um modo determinável de crença. A história da filosofia deve, não redizer o que o filósofo disse, mas dizer o que ele necessariamente subentendia, o que ele não dizia e que, no entanto, está presente naquilo que diz. (DELEUZE, 2004, 169)

Segundo os dois filósofos, os conceitos filosóficos podem tanto ser ferramentas de conservação como de transformação. Além disso, eles operam no âmbito dessas condições. Em outras palavras, os conceitos produzem sentido. Por isso, Deleuze buscou definir, em primeiro lugar, a lógica do sentido e buscou na reversão do simulacro de Platão e nos incorpóreos dos Estóicos, as bases de sua filosofia que questiona a noção do Ser, a questão ontológica.

Os Estóicos foram os filósofos da era helenística, os filósofos de uma Grécia derrotada e submissa e, dessa forma, sua filosofia é mais realista e voltada aos problemas imediatos, menos preocupada com os cidadãos e mais voltada ao indivíduo e aos problemas da vida. Ela é mais cínica, apática e repudia a grande cultura. Os estóicos tinham uma concepção de mundo como um eterno vir-a-ser, como algo indefinido, da maneira de Heráclito (MARCONDES FILHO, 2005).

\section{$2^{\circ}$.2.1. O devir e o tempo de Aion}

Para os estóicos, existe um puro devir que é ilimitado e que está presente no conceito de simulacro de Platão. Dessa forma, a filosofia deleuzeana afirma que não existem categorias, como as classes, as espécies e os gêneros, desenvolvidas pelo pensamento de Aristóteles. Segundo o pensamento de Deleuze (2003), as categorias aristotélicas são devires. Os devires não são transformações físicas ou metamorfoses, são composições, conjuntos que formam uma imagem, uma emissão de partículas que entram movimento, em intensidade. Os devires são sempre minoritários, sempre frágeis. Os devires não são uma correspondência de relações, são, em última instância, identificações. Entretanto, não seguem uma série progressiva, um desenvolvimento. 
O devir é da ordem da aliança. Um devir é sempre um bando, uma matilha. Cardumes, manadas, populações, afectos e potências, involuções. Dessa forma, um homem não é só um homem, cópia imperfeita de uma Essência. Um homem pode devir mulher, um animal pode devir flor, uma mulher pode devir criança. É uma propagação por epidemia, por contágio, como o conjunto homem-animal-bactéria, como o conjunto trufa-árvore-mosca-porco, como o conjunto giz-ardósia-papel-tinta-adulto-criança.

Há um bloco de devir que toma a vespa e a orquídea, mas do qual nenhuma vespa-orquídea pode descender. Há um bloco de devir que toma o gato e o babuíno, e cuja aliança é operada por um vírus C. Há um bloco de devir entre raízes jovens e certos micro-organismos, as matérias orgânicas sintetizadas nas folhas operando a aliança (rizosfera). (DELEUZE; GUATTARI, 1997, 19)

Além da reversão do Platonismo, Deleuze buscou na filosofia estóica uma nova maneira de pensar a noção de tempo. O senso comum aceita o tempo ordenado numa única direção, o tempo cronológico, o tempo de Cronos. Os Estóicos, além de aceitar o tempo de Cronos, compreendem o tempo de Aion - o tempo não cronológico, gênese dos paradoxos, a dinâmica daquilo que acontece, que não se detém nunca no presente, mas remete sempre ao passado e ao futuro.

Só o presente existe no tempo, absorvendo o passado e o futuro, mas só o passado e o futuro insistem no tempo, dividindo o presente ao infinito.

Como diz Emile Bréhier na sua bela restituição do pensamento estóico: "Quando o escalpelo corta a carne, o primeiro corpo produz sobre o segundo não uma propriedade nova, mas um atributo novo, o de ser cortado. $\mathrm{O}$ atributo não é nenhuma qualidade real..., é sempre ao contrário expresso por um verbo, o que quer dizer que não é um ser, mas uma maneira de ser... esta maneira de ser se encontra de alguma forma no limite, na superfície de ser e não pode mudar sua 
natureza: ela não é a bem dizer nem ativa nem passiva, pois a passividade suporia uma natureza corporal que sofre uma ação. Ela é pura e simplesmente um resultado, um efeito não classificável entre os seres [...] [Os estóicos distinguem] radicalmente, o que ninguém tinha feito antes deles, dois planos de ser: de um lado o ser profundo e real, a força; de outro, o plano dos fatos, que se produzem na superfície do ser e instituem uma multiplicidade infinita de seres incorporais". (DELEUZE, 2003, 6)

Aceitar o paradoxo do devir é afirmar que existem os dois sentidos ao mesmo tempo, porque ele destrói o bom senso como sentido único e em seguida destrói o senso comum como designação de identidades fixas. Assim, o simulacro, o devir-louco, o devir-ilimitado, livre de julgamentos da Idéia, sobe à superfície das Idéias, acima do Bem e do Mal.

A principal conseqüência da associação entre o tempo e o paradoxo do devir reside no questionamento da Opinião, da Doxa. No plano da Doxa circulam o bom senso, como sentido correto, direção única das coisas, e o senso comum, como reconhecimento do Mesmo, na esfera dos sujeitos, dos objetos, da identidade e da subjetividade. O paradoxo subverte ao afirmar simultaneamente várias direções. Assim, o tempo pode ser apreendido duas vezes: inteiro no presente e inteiro no infinito.

O paradoxo subverte a direção da flecha do tempo ao abolir o princípio da direção única, mas, sobretudo coloca em xeque o presente que lhe serve de parâmetro, presente em que aquela se ancora ou do qual ela parte. O paradoxo furtase ao presente e esquiva-o, instalando na divisão infinita do instante e afirmando concomitantemente os vários sentidos, numa temporalidade centrífuga, multilinear. [...] Ao afirmar ao mesmo tempo múltiplos sentidos, várias direções, sua coexistência insuperável, o paradoxo sabota a recognição e seus postulados implícitos, a identidade do sujeito que reconhece, a permanência do objeto reconhecido, a 
mensuração e limitação das qualidades a ele atribuídas, e reintroduz o devir-louco que a recognição se encarregava de proscrever. (PELBART, 1998, 65).

Aceitar o devir e o tempo não-cronológico muda o modo como pensamos a relação causaefeito. Para os estóicos, no tempo presente existem os corpos e sua tensão recíproca. Todos os corpos são causas em relação uns com os outros, e a unidade das causas é o Destino. Além disso, os corpos são causas dos acontecimentos da superficie, acontecimentos que são incorporais. Os acontecimentos são efeitos, resultados de ações e paixões dos corpos, e são infinitos por que estão sempre se esquivando do presente. São passado e futuro e nunca presente. Para os estóicos, o corpo, o profundo, é a causa dos acontecimentos incorporais da superfície, e não o seu contrário.

Os corpos e suas qualidades e quantidades, a profundidade dos corpos, são misturas. Mas, os atributos dos corpos são acontecimentos incorporais da superfície que resultam dessas misturas. Os incorpóreos acontecem na linguagem. Deleuze utiliza uma bela imagem para essa relação:

Dir-se-ia que a antiga profundidade se desdobrou na superfície, converteu-se em largura. O devir ilimitado se desenvolve agora inteiramente nesta largura revirada. Profundo deixou de ser um elogio. [...] Os acontecimentos são como cristais, não se transformam e não crescem a não ser pelas bordas, nas bordas. (DELEUZE, 2003,10)

Essa forma de pensar opera uma cisão totalmente nova da relação causal: as causas (um corpo) têm relação entre si, e os efeitos têm relação entre si (um corte, uma ferida, uma cicatriz), mas não funcionam como causas entre si, são "quase-causas", pois suas causas estão nos corpos da profundidade. Essa dissociação entre os corpos e os incorpóreos nos remete sempre à linguagem, "à existência de uma declinação das causas, ou seja, à existência de uma conjugação dos efeitos" (id., ibid., 7). 


\section{$2^{\circ}$.2.2. A linguagem na filosofia deleuzeana}

Para Deleuze e Guattari, antes da estrutura da linguagem, vem a função. A estrutura depende da função. E a principal função da linguagem é agenciar: agenciar fluxos, agenciar devires. A filosofia deleuzeana compreende a pragmática, ou o uso da linguagem, como o elemento de base de que dependem a lógica, a sintaxe e a semântica. Ao contrário da lingüística, que entende a pragmática como o estudo daquilo que foge às constantes da linguagem, Deleuze e Guattari entendem a pragmática como a condição mesma da linguagem.

Essa idéia é muito providencial por que vivemos um momento em que os estudos da lingüística colocaram a pragmática numa encruzilhada e fizeram com que perdesse sua definição como campo de estudos. Em educação, quem sofre essa mesma crítica é a didática. Por ter um caráter interdisciplinar e não específico, a didática vem sendo tratada como um campo indefinido. A filosofia deleuzeana, pelo contrário, ao pressupor como base filosófica um empirismo radical, um empirismo que privilegie a relação entre os conceitos e a vida, compreende o uso e a função das ciências. Por essa via, a educação é, antes de tudo, prática, uso, variação.

Da mesma forma, a filosofia deleuzeana pressupõe a relação entre os elementos da linguagem - sempre em variação - e a vida, não aceitando a separação vida-linguagem, e muito menos entendendo a linguagem como representação do real. Diferentemente da definição do estruturalismo que explica que a linguagem é formada pelo par significante e significado, Deleuze e Guattari buscaram suas idéias sobre linguagem dos estudos do lingüista Hjelmslev, que formulou a noção de que os signos são "uma solidariedade entre uma forma de expressão e uma forma de conteúdo, que se manifestam por uma substância de expressão e uma substância de conteúdo" (MALBERG apud ALMEIDA, 2003). Hjelmslev chamou sua lingüística de lingüística de fluxos, uma lingüística imanente, que abdica de uma concepção de linguagem transcendental, baseada em entidades prévias.

Para Hjelmslev, nem o significante pode expressar as coisas (expressão), nem o significado pode representar aquilo a que se refere (conteúdo). Mais do que uma relação significante-significado, o que existe é uma relação de pressuposição recíproca conteúdoexpressão. Assim, ao invés de uma linguagem formada por signos, que carregam uma significação e que têm como oposto não-signos, o lingüista propõe que a linguagem é sempre formada por não-signos, ou seja, os signos sem significado, as figuras. $\mathrm{O}$ oposto a essas figuras 
seria a substância semioticamente não formada, a que o lingüista deu o nome de matéria. Ele sugere uma nova repartição do campo semiótico: ao lado das formas e substâncias formadas (de expressão e de conteúdo) existe um campo de substâncias semioticamente não formadas, de matérias desestratificadas.

Para Deleuze (DELEUZE; PARNET, 1998), essa matéria não-formada abre caminho para o estudo de semióticas independentes de semiologias significantes, que não estão fundadas sobre a bipolaridade significante-significado. Na filosofia deleuzeana, a idéia de estratificação e desestratificação, de formalização e de aformalização é essencial. Ela permite a idéia de função da linguagem.

Para a filosofia deleuzeana, quem usa a linguagem não é um Eu, nem uma consciência. É algo que não é nem individual nem pessoal e que, no entanto, é singular, algo que salta de uma singularidade para outra. Uma singularidade que percorre homens, plantas, animais. Quem se expressa na linguagem é uma máquina de expressão. A expressão é uma máquina semiótica coletiva que enuncia. Uma máquina abstrata.

O conteúdo expresso pela máquina de expressão não é o objeto, o referente ou o significado. O conteúdo é uma prática, um regime de corpos, é um enunciado nos moldes foucaultianos. Como já foi dito, segundo Foucault (2004), um enunciado possui um espaço de correlações, um sujeito, um campo associado e uma materialidade. Tal como a expressão, o conteúdo ou enunciado possui forma e substância, e é por excelência, tecnológico. O conteúdo opera modificações no mundo exterior, o conteúdo age no mundo. $O$ enunciado não é ideologia, não há ideologia. O conteúdo é uma máquina social técnica que torna visível, que "visibiliza".

As formalizações de expressão e de conteúdo se dão em agenciamentos, conjuntos de vizinhança homem-utensílio-animal-coisa. Um agenciamento é ao mesmo tempo um agenciamento maquínico de expressão e um agenciamento coletivo de enunciação. A linguagem, ou qualquer formalização da expressão, existe apenas enquanto forma engajada em um agenciamento complexo e coletivo, que lhe fornece consistência. Nos agenciamentos, os devires se territorializam, mantêm-se. Os agenciamentos são invenções, são culturas, são "idades" da história, são quadros, são livros, são encontros.

Os agenciamentos são formados por formalizações de expressão $e$ de conteúdo que se dão em estratos, e eles são, também, formados por desestratificações, movimentos, fugas. Todo agenciamento pode ser medido pelos movimentos de territorialização, desterritorialização e 
reterritorialização que acontecem em seus fluxos, movimentos que conjugam formas, estabilizando-as, e que também as desmancham, "desformando-as". Todo agenciamento possui uma tetravalência: conteúdo, expressão, estratos, ou territórios, e linhas de desestratificação, de desterritorialização (ALMEIDA, 2003).

Territórios e desterritorializações não são opostos, não possuem uma relação dual, pelo contrário, eles fazem parte de um plano de consistência, um plano onde todas as metáforas são abolidas, onde tudo é Real. Deleuze e Guattari (1995a) definem os estratos como recaídas, como reterritorializações, porque o plano de consistência é traçado pela Máquina Abstrata, que existe "simultaneamente desenvolvida no plano desestratificado que traça, mas envolvida em cada estrato cuja unidade de composição define e mesmo erigida pela metade em certos estratos cuja forma de preensão ela também define” (id., ibid., 87). O plano de consistência não é o caos. Ele é carregado de estratos, de lembranças, de tensões. Ele constrói contínuos de intensidade, emite e combina signos-partículas, opera conjunções de fluxos de desterritorialização. O caos é o Fora, o exterior.

Para a filosofia deleuzeana, todo o problema da linguagem está preso à análise dos agenciamentos.

Dado um enunciado, dado um conjunto de signos, nosso problema primeiro é saber qual agenciamento ele efetua, de que regime de signos participa, em que ponto cruza as formas de conteúdo, com que velocidade se aproxima do plano de consistência, se é potência criativa e alonga-se em direção aos limites (desterritorialização) ou se forma blocos de captura (reterritorialização). Montagem e desmontagem de agenciamentos, linhas, forças, materiais. (ALMEIDA, 2003, 62)

A teoria do agenciamento permite que aceitemos que um livro, uma configuração artística, uma música, não representam ou imitam o mundo, mas sim, que possuam conexões com elementos de diversas ordens, em diversos estratos. Ao invés de separar mundo-linguagemsujeito, o agenciamento compreende a multiplicidade de uma expressão e de um conteúdo. Um 
livro, por exemplo, é uma multiplicidade de linhas, um composto de matérias, que se interligam por movimentos de territorialização e desterriotorialização, sempre em relação a outros processos, como a máquina que o imprimiu, a árvore que originou seu papel, a memória de quem utilizou a língua escrita para escrevê-lo, a forma das letras, o sentimento que ele suscita, a época em que é lido. É sempre uma inter-relação de um campo real (mundo), um campo de representação (linguagem) e um campo de subjetivação (sujeito-autor), mas não parte de uma Idéia, de uma transcendência, de um sujeito. Um livro faz parte do movimento rizomático da Imanência, um movimento de superfície, ramificado, gramíneo.

\section{$2^{\circ}$.2.3. Os diferentes estratos do agenciamento}

A questão que se coloca, então, é como se dão as estratificações? Como se dão a nomeação e a identificação das coisas? Quando os signos surgem? Segundo os filósofos: “[...] $e$ ' difícil expor o sistema dos estratos sem parecer introduzir entre eles uma espécie de evolução cósmica ou mesmo espiritual, como se eles se ordenassem em estágios e passassem por graus de perfeição” (DELEUZE; GUATTARI, 1995a, 86). Entretanto, os estratos não seguem uma seqüência ordenada, eles possuem pressuposição recíproca, disseminam-se uns nos outros. Um estrato serve de substrato a outro, fazendo com que o agenciamento maquínico funcione como um metaestrato. O que varia de um estrato a outro é a natureza da distinção entre conteúdo e expressão.

A filosofia deleuzeana define três tipos de diferenciação entre as formas de expressão e de conteúdo, sendo que nas três há sempre uma distinção real entre expressão e conteúdo:

- Distinção real-formal, onde se instaura uma ressonância de expressão. Nesse estrato, geológico, conteúdo e expressão diferem-se pela dimensão, e ligam-se por indução, por sugestão. Aqui, a expressão determina o conteúdo, como se fosse um molde. Por exemplo: um cristal expressa sua forma a um meio amorfo que lhe é exterior, mas que, ao mesmo tempo, é interiorizado e incorporado pelo germe que originou o cristal. Meio e cristal se comunicam por indução, estratificando um bloco de devir germe-meio-cristal.. 
- Distinção real-real, onde se instaura uma linearidade de expressão. Nesse estrato, orgânico, expressão e conteúdo possuem a mesma dimensão, mas diferem realmente, e se ligam por transdução, por um processo pelo qual uma energia se transforma em outra de natureza diferente. Aqui, a expressão vai de um estado a outro, continuamente, ela se reproduz, ela é autônoma, e possui um limiar de desterritorialização. Por exemplo: a molécula expressa porque ela percebe e reage em relação a outras moléculas com as quais troca energia e cria vida, constituindo o meio associado, produzindo novos estratos, inclusive, cruzando espécies, interferindo nelas. Um vírus, por exemplo, comunica-se com as outras espécies por transdução, estratificando um bloco de devir macaco-virus-homem.

- Distinção real-essencial, onde se instaura uma sobrelinearidade de expressão. Nesse estrato, linguageiro, a forma do conteúdo torna-se lingüística, opera por símbolos compreensíveis e opera modificação no mundo exterior. Conteúdo e expressão, aqui, se ligam por tradução. Aqui, a expressão se dá por intermédio dos signos, a partir de sujeitos, que não são necessariamente uma essência humana. Aqui, a expressão desterriotorializa as coisas do mundo e dos seres, criando novas funções, novos usos, novas ferramentas. Por exemplo: a mão, como forma geral de conteúdo, se prolonga nas ferramentas. Além desse aspecto, a expressão compõe conjuntos de traços formais, as línguas formais, que também transforma as substâncias e as coisas, desterritorializando-as. Por exemplo: a desterritorialização da boca, que perde sua função de receber alimentos, para liberar palavras e sons codificados (id., ibid, 73-78). Nesse estrato, a comunicação se dá por tradução, estratificando um bloco de devir sujeito-signo-ferramenta-objeto. A tradução é diferente em cada agenciamento, não seguindo um padrão de significação transcendente.

A unidade elementar da linguagem que se dá no estrato linguageiro não é o signo, é a palavra de ordem. Segundo Deleuze e Guattari (1995b): 
Chamamos palavras de ordem não uma categoria particular de enunciados explícitos (por exemplo, no imperativo), mas a relação de qualquer palavra ou de qualquer enunciado com pressupostos implícitos, com atos de fala que se realizam no enunciado, e que se podem realizar apenas neles. (id., ibid., 16).

As palavras de ordem redundam nas palavras e nos atos, na disciplina da gramática. Para os filósofos, é a palavra de ordem que faz da palavra, ou de qualquer outra unidade de linguagem, uma enunciação nos moldes foucaultianos: uma função que possui um conjunto de condições de existência. As palavras de ordem são pressupostos implícitos, são regimes de signos que perpassam a sociedade e formam regimes mistos, que se transformam, redundando as mesmas palavras. É o discurso indireto, sempre presente, sempre imanente.

O discurso indireto é a presença de um enunciado relatado em um enunciado relator, a presença da palavra de ordem na palavra. É toda a linguagem que é discurso indireto. Ao invés de um discurso indireto supor um discurso direto, é este que é extraído daquele, à medida que as operações de significância e os processos de subjetivação em um agenciamento se encontram distribuídos, atribuídos, consignados, ou à medida que as variáveis do agenciamento estabelecem relações constantes, por mais provisórias que sejam. (id., ibid., 23).

Entretanto, existe uma outra função da linguagem que acontece no estrato linguageiro e que ultrapassa os limites e os restitui à equivalência infinita de um devir ilimitado, de uma identidade infinita. Quando nessa função, a linguagem pode não ser um código, não ser transmissão de informações. Segundo Deleuze e Guattari (ibid.), o que se opõe à linguagempalavra de ordem não é aquilo que chamamos de ruído, mas a indisciplina das linguagens sem ordem, sem estrutura, a linguagem agramatical. No movimento de desterritorialização dos devires, a expressão se dá desordenadamente. 
Ele justifica a existência dessa função não como algo ruim, errado, falso. A significação, para Deleuze (2003) não é a verdade ou a mentira, é apenas uma condição da linguagem. Portanto, a significação não fundamenta a verdade, ela a condiciona.

O uso menor da linguagem pode ser entendido como a produção de arte, e o uso menor da língua como a produção de literatura. Segundo Julia Almeida (2003)

O modo de expressão da literatura seria o da criação proliferante de potências gramaticais, tendendo o conjunto ao agramatical, que não é simplesmente uma expressão desviante a que se chega, mas está lá, desde o início, na proliferação de gramaticais, na descoberta de novas potências gramaticais, na compossibilidade dos divergentes, na elevação da série a um finito-ilimitado. (id., ibid., 218) [grifo nosso]

Dessa forma, compreende-se que a linguagem não é apenas representação, uma imagem do mundo, nem que sua função principal seja comunicar informações. A linguagem é sempre relativa a um agenciamento, aos processos de territorialização e desterritorialização, no meio de um rizoma ${ }^{14}$. É um processo que não para de se formar, feito de dimensões, direções movediças, que não tem começo nem fim, um processo feito de platôs que estão sempre no meio de agenciamentos do desejo que trabalham sobre fluxos semióticos, fluxos materiais e fluxos sociais.

\section{$2^{\circ}$.2.4. O pensamento complexo e a comunicação como redundância}

A filosofia da Diferença enquadra-se no pensamento complexo. A teoria do pensamento complexo entende que pensamento (ou consciência), linguagem, verdade, razão, sujeito, objeto são inseparáveis, e não partes separadas que possuem uma existência em si. Elas são partes que

${ }^{14}$ Em Mil Platôs, Deleuze e Guattari (1995a) trabalham dois tipos de imagem do pensamento, de um lado o modelo raiz, do outro o rizoma. O pensamento rizomático é acentrado e não hierárquico, é criador de diferenças, consistência e sentido. Ele é um sistema aberto apto a montar cadeias, ou seja, é o pensamento não acabado que busca realizar ressonâncias entre planos distintos. 
se inter-relacionam e se confrontam, para poder existir. Dessa forma, a linguagem mistura-se com o pensamento e com o conceito de sujeito, e passa a ser encarada como uma rede de significações e atribuições, e não apenas uma representação do real.

Para o pensamento complexo, aquilo que entendemos como homem está em constante transformação, em constante organização paradigmática, constantemente se autoproduzindo. Essa autoprodução acontece em relação à linguagem, ao objeto, à verdade, à razão, e aceita uma causalidade circular: o efeito é ao mesmo tempo causa. Nesse sentido, a significação não está presente apenas no signo, que precisa ser interpretado por alguém. Ela é uma busca imanente porque a busca pelo sentido é imanente. Por isso, para o pensamento complexo, o signo é uma unidade que faz parte do processo contínuo e infinito de produção de sentido. Em outras palavras, para o pensamento complexo a combinação de signos está presente na significação, mas a própria significação, entendida como criação de sentido, está sempre em suspenso, sempre imanente.

Por esse prisma, a comunicação como transmissão de mensagens por um canal com o mínimo de ruído possível, torna-se um idealismo. É impossível negar o ruído na comunicação, porque o ruído, entendido como a não decodificação da mensagem pelo receptor, faz parte da complexidade do processo de significação. Ele é a desterritorialização presente no agenciamento. As subjetividades, os sentimentos, as sensações, as cargas ideológicas, as tradições culturais, estão sempre presentes e fazem parte desse processo interferindo no fluxo de informações, elas interferem no processo de transmissão de mensagens. Entender a transmissão de mensagens como algo límpido, puro, sem interferências, é irreal, ou, ideal.

Quando pensamos a comunicação dentro da complexidade, percebemos o quanto ela faz parte da produção de sentido feita em conjunto com todos os elementos do processo de significação e com a realidade que permeia esse processo. Nesse sentido, a comunicação se dá nos agenciamentos. Dessa forma, mais que transmissão de mensagens, podemos compreender a comunicação como uma redundância de mensagens em um agenciamento. Como já foi dito no primeiro capítulo dessa dissertação, para a teoria da informação de Shannon, na economia dos processos comunicacionais, uma informação pode ser mais ou menos codificável, ou seja, ela possui um determinado coeficiente de comunicação. A esse coeficiente dá-se o nome de redundância. Quanto mais redundante, mais decodificável é a informação (MATTELART, A. e M., 2002). 
Essas idéias estão de acordo com a pesquisa que vem sendo realizada pelo departamento de Filosofia da Comunicação da ECA-USP (Filocom), coordenado pelo professor Ciro Marcondes Filho. Desde meados dos anos 80, o Filocom vem buscando uma nova Teoria da Comunicação. A introdução maciça das novas tecnologias digitais, a crise dos modelos ideológicos de diagnóstico da realidade e o novo quadro social inaugurado pela chamada pósmodernidade foram as causas da revisão conceitual proposta pelo Filocom. O departamento realiza uma proposta, ainda em fase de construção, para o campo das ciências da comunicação capaz de renovar o campo teórico, de incorporar a nova realidade e de apresentar um outro método de investigação científica para os processos de comunicação.

No livro “O escavador de silêncios”, Ciro Marcondes Filho (2005) propõe que a:

Comunicação é o resultado de três seleções: um agente sinaliza alguma coisa, eu percebo nisso uma intenção de comunicar e, por fim, eu entendo que esse agente está se comunicando comigo. Ou então, a síntese entre um sinalizar, um informar e um entender a diferença entre o sinalizar e o informar. [...] para haver comunicação é preciso, pelo menos, haver dois agentes: um Ego e um Alter, que não são necessariamente pessoas, mas elementos de um sistema, ou mesmo, de certas circunstâncias, os próprios sistemas enquanto agentes da comunicação. Eles estão num mesmo universo de referência ou contexto de relação, o que viabiliza o contato. [...] quando eu entendo a intencionalidade do outro, é a comunicação. (id., ibid., 458).

Para o grupo, a comunicação é um processo social, um acontecimento, uma combinação de múltiplos vetores (sociais, históricos, subjetivos, temporais, culturais), que se dá pelo atrito dos corpos e das expressões, algo que ocorre num ambiente, permitindo que se realize, a partir dela, algo novo. Os grandes meios de comunicação - a televisão, os jornais, as emissoras de rádio, as publicidades de rua - podem veicular signos comunicacionais, mas isso não significa necessariamente que eles comuniquem, pois é preciso que ocorra o evento comunicacional. Este 
não acontece necessariamente entre pessoas que se relacionam para essa finalidade, mas acaba necessariamente acontecendo na presença muda, nos olhares, no contato dos corpos. O tempo dessa comunicação se realiza apenas no momento em que se identifica a distinção entre um mero sinal e uma informação. Para haver entendimento, é necessário que haja uma continuidade de comunicação, é preciso que haja a criação de um processo comunicacional, uma seqüência de seleções.

Dessa forma, parte-se para um segundo nível de comunicação, que é a comunicação no plano dos sistemas sociais, fora da intersubjetividade, a comunicação como manutenção da autoprodução desses mesmos sistemas. Os sistemas sociais produzem comunicação entre eles e entre eles e o meio, dessa forma, o meio externo é observado pelo sistema e vice-versa. Ou seja, quando os atores da comunicação não estão perto uns dos outros, quando eles estão distantes, o que os une é a comunicação que um sistema faz ao outro através da comunicação sobre o meio externo àquele sistema social (sobre o clima, sobre os fatos acontecidos, sobre a política, sobre um outro sistema social, etc...). Nessa forma de comunicação é muito difícil haver o entendimento e a compreensão das mensagens de forma imediata, por isso, requer repetição.

Comunicar não é transmitir mensagens. É redundar informações num pulsar constante, é a seletividade que se constrói no processo de comunicação. O entendimento é um entendimento passageiro, e não chega a ser um consenso, é um acordo passageiro. Nesse sentido, os meios de comunicação não são apenas os meios diretos e os meios de massa, são também os meios simbolicamente generalizados de comunicação, os meios improváveis.

[...] [Esses meios] são componentes dos sistemas sociais e sua função é assegurar possibilidades de sucesso à comunicação, transformando improbabilidade em probabilidade. Esses meios são o poder, a verdade cientifica, o dinheiro, o amor, a arte, os valores. Aceita-se uma comunicação antes improvável porque, caso contrário, pagase multa, porque se trata de uma verdade científica, porque se ama a pessoa, etc.. estes meios vinculam seleção e motivação e tornam possível que a seleção de Alter seja base para as posteriores seleções de Ego. Isso não implica que o sistema 
psíquico tenha sido cooptado. Pode-se aceitar mantendo-se internamente a recusa. (id., ibid., 467).

Dessa forma, a comunicação é aceita como um mecanismo de auto-regulação, um modo como um sistema observa-se a si próprio e aos outros, ou mesmo, ela é que torna possíveis os sistemas sociais. Os signos gerados na comunicação são um julgamento, sempre em movimento, em busca de sentido, e os media, são elementos que podem ser livremente acoplados ao processo de comunicação, são como uma forma criada durante o processo, uma singularidade que surge e que pode se desmanchar a qualquer momento.

A comunicação é uma forma de possibilidade de formação de estratos, de territorializações que tornam atuais as verdades, que são múltiplas. A comunicação funciona tanto como um processo, no qual acontece a produção de diferenças e também como uma observação, que cria o sentido. Tanto o processo quanto a observação se dão no movimento, no fluxo. Quanto mais redundante for uma mensagem, mais ela se torna presente num determinado sistema ou agenciamento. Uma mensagem, que não possui um emissor original, mas vários, vindos de uma longa cadeia de emissores no tempo e no espaço, e pode manter-se num determinado agenciamento com uma potência mais forte ou mais fraca.

\section{$2^{\circ}$.2.5. Linguagem e poder}

Os agenciamentos são passionais, e são, por isso, agenciamentos do desejo. Segundo Deleuze e Guattari (1995a), o desejo nada tem a ver com uma determinação natural ou espontânea, só há desejo agenciado, maquinado. É em agenciamentos do desejo que podemos reconhecer os dispositivos de poder, já que, para os filósofos, o poder é uma afecção do desejo. É nos agenciamentos que se dão as formas subjetivas e os processos de subjetivação, que "dobram" os fluxos de imagem, de som, de palavras, de matérias orgânicas, de sentimentos (ALMEIDA, 2003).

Para Deleuze e Guattari (1996), em toda relação de poder existe uma mescla de macro e micropolítica, uma fina textura que está entre os dois pólos da luta pelo poder. Essa mescla e essa textura 
[...] encontram aí ao mesmo tempo o princípio de sua potência e o fundo de sua impotência. E longe de se oporem, a potência e a impotência se completam e se reforçam mutuamente, numa espécie de satisfação fascinante que encontramos entre os mais medíocres homens de Estado, que define sua "glória". (id., ibid., 107).

Essa textura, o terceiro elemento da relação de poder, é o desejo, um processo imanente que varia entre potência e impotência. No caso especifico do desejo do poder, ele pode se processar tanto na sua potência quanto na sua impotência ao rebater de um lado, nos que controlam, e de outro, nos que são controlados. Por isso, a luta não se restringe apenas ao plano da economia política, ela abrange também o plano da economia subjetiva, abrange o modo como os indivíduos e grupos entendem viver sua existência.

Por isso, ao contrário do modelo tradicional marxista que define a sociedade pelas suas contradições, a filosofia deleuzeana entende que "uma sociedade se define por suas linhas de fuga, que são moleculares “(DELEUZE; GUATTARI, 1995a, 94). Porque é nas linhas de fuga que acontece "o primado do desejo" (DELEUZE, 1994). O desejo se confunde com elas. A essa potência do desejo, Deleuze e Guattari (1996) chamam de revolução molecular, que acontece num nível micropolítico e que é o mesmo lugar do controle: a subjetividade.

Um processo de singularização [sic] da subjetividade pode ganhar uma imensa importância, exatamente como um grande poeta, um grande músico ou um grande pintor, que, com suas visões singulares da escrita, da música ou da pintura, podem desencadear uma mudança nos sistemas coletivos de escuta e visão. (GUATTARI; ROLNIK, 2005, $65)$.

Segundo Guattari (op. cit.), qualquer emergência de singularidade provoca dois tipos de resposta micropolitica: uma resposta normalizadora, que a ignora ou que a integra, ou uma 
resposta construtora, que busca levar a singularidade para a construção de um processo de mudança.

$$
\begin{aligned}
& \text { O traço comum entre os diferentes processos de } \\
& \text { singularização é um devir diferencial que recusa a } \\
& \text { subjetivação capitalística. Isso se sente por um calor nas } \\
& \text { relações, por determinada maneira de desejar, por uma } \\
& \text { afirmação positiva da criatividade, por uma vontade de amar, } \\
& \text { por uma vontade de simplesmente viver ou sobreviver, pela } \\
& \text { multiplicidade dessas vontades. É preciso abrir espaço para } \\
& \text { que isso aconteça. O desejo só pode ser vivido em vetores de } \\
& \text { singularidade. (id., ibid., 56). }
\end{aligned}
$$

Na sociedade capitalista, o controle da "massa", através do processo de dominação da cultura de massa e dos media, acaba por se efetivar num controle de cada indivíduo, num controle atomizado. A sociedade capitalista, através do mecanismo da Identidade, mesmo que num tipo de identidade fragmentada e variável, as subjetividades são formatadas e modelizadas, invoca um Indivíduo especial que se distingue da massa, mas não uma singularidade que aconteça a partir de devires e de processos coletivos.

Vários pensadores, como Stuart Hall (2001), Zigmunt Bauman (1998, 2001), Lyotard (1998), Prost (1995) e Anthony Giddens (1991), nos alertam sobre a questão da privatização da vida pública, em nosso tempo. Não temos mais espaços públicos, não temos mais momentos de reunião e de consensos em que possamos exercitar um pensamento comum. O próprio modelo social da modernidade impôs essa privatização, que não é uma singularização e sim uma individuação.

Entretanto, Deleuze e Guattari (1996), ao perceber o processo dinâmico das transformações sociais e históricas, acreditam numa resistência biopolítica ao poder biopolitico: a vida como resistência, a resistência molecular, a revolução molecular, os processos de luta que se dão na liberação de fluxos de desejo fora dos padrões modelizados pelo sistema e fora dos padrões impostos na cultura popular tradicional. São individuações que acontecem fora dos padrões impostos pelo sistema social: são singularizações. O que move a singularização é o desejo, um profundo desejo de justiça que se vivencia também na profunda indignação com o 
sofrimento do povo pobre, oprimido e marginalizado. Nenhuma teoria crítica, por mais crítica que seja, será capaz de mover as massas se não for capaz de agenciar os seus desejos.

Nesse ponto, fica impossível não falar sobre educação. De que forma pensar uma educação que se dê num agenciamento que permita o uso menor da linguagem e da comunicação, que agencie desejos e permita processos de singularização? 


\section{$3^{\circ}$. UMA EDUCAÇÃO RIZOMÁTICA}

\section{$P$ de professor}

[...] Acho que as aulas têm equivalentes em outras áreas. Uma aula é algo que é muito preparado. Parece muito com outras atividades. Se você quer 5 minutos, 10 minutos de inspiração, tem de fazer uma longa preparação. [...] Sempre fiz isso, eu gostava. Eu me preparava muito para ter esses momentos de inspiração.

[...] Uma aula é ensaiada. É como no teatro e nas cançonetas, há ensaios. Se não tivermos ensaiado o bastante, não estaremos inspirados. Uma aula quer dizer momentos de inspiração, senão não quer dizer nada. [...] cada atividade tem seus modos de inspiração. Mas não há outra palavra a não ser pôr algo na cabeça e conseguir achar interessante o que é dito. Se o orador não acha interessante o que está dizendo... Nem sempre achamos interessante o que dizemos. E não é vaidade, não é se achar interessante ou fascinante. É preciso achar a matéria da qual tratamos, a matéria que abraçamos, fascinante. Às vezes, temos de nos açoitar. Não que seja desinteressante, a questão não é essa. É necessário chegar ao ponto de falar de algo com entusiasmo. O ensaio é isso.

Gilles Deleuze 
No capítulo anterior, apresentei alguns aspectos do pensamento deleuzeano, principalmente em relação à linguagem, e alguns aspectos da Nova Teoria da Comunicação, desenvolvida pelo Filocom. Na visão de Deleuze e Guattari, a linguagem é encarada como uma rede de significações e atribuições, e não apenas uma representação do real, e possui diferentes usos, podendo ser menor ou maior. Além disso, compreende que o produtor é ao mesmo tempo produto, ou seja, tanto o sujeito quanto o objeto do conhecimento são efeitos de um agenciamento coletivo que pode propiciar, ou não, processos de singularização, por conta dos jogos do poder. Por essa via, a comunicação passa a ser encarada como uma redundância de mensagens em um sistema e uma observação desse mesmo sistema, que tem como fim regula-lo e integrá-lo. Isso implica em uma mudança radical no modo como entendemos a cognição e o ensino, e, conseqüentemente, no modo como entendemos o saber.

É muito providencial, para os nossos dias, buscar novos modos de entender a cognição, o ensino e o saber. O agenciamento coletivo de que fazemos parte é tão carregado de informações e mensagens que a atenção de todos se dispersa. Entretanto, um olhar mais atento nos faz ver que essa dispersão é política, principalmente porque não são todas as mensagens que se perdem: algumas são transmitidas de forma mais intensa, constante e redundante que outras. $\mathrm{O}$ ruído na comunicação, ou a baixa capacidade de decodificação de determinadas mensagens em relação a outras, é sempre político. A questão, portanto, é saber quais são as mensagens que redundam mais, ou seja, quais são as mensagens que comunicam com maior potência de decodificação.

Não é preciso muitas evidências para concluir que as crianças "decodificam” de forma muito competente as mensagens que enfocam os ideais neoliberais de individualismo e consumismo que redundam na sala de aula social. Em nossos dias, as crianças aprendem a consumir de forma muito mais competente do que aprendem, por exemplo, a ler e escrever no agenciamento escolar, principalmente porque as mensagens sobre o consumo redundam demais e ditam palavras de ordem a todo o momento e em todo o lugar.

Nesse contexto, a escola pode ser um lugar de resistência, de insistência. Um lugar do pensamento e da criação e um verdadeiro agenciamento de ensino e de aprendizado. Entretanto, o que constatamos pelas ações governamentais e da sociedade civil é que a saída encontrada para o problema da dispersão e da falta de atenção dos alunos (que freqüentemente é entendido como conseqüência da total falta de comunicação dialógica de nossos dias), é utilizar os media como recurso didático. A principal justificativa para esse uso é despertar o interesse dos alunos, 
trazendo a sua "cultura" para dentro da sala de aula, e buscando aproximar a escola da realidade do aluno.

Entretanto, utilizar os media como recurso didático num modelo de educação que compreenda a linguagem como representacional não vai alcançar os objetivos buscados e vai apenas torná-la mais tecnológica. A história da educação comprova minha afirmação: em 1930, por exemplo, quando se buscou evitar a evasão escolar e manter os alunos na escola, foram montadas bibliotecas nas escolas públicas. Nessas bibliotecas, algumas escolas organizaram seu Jornal Infantil a fim de "dar voz" aos alunos. Entretanto, os diretores e os professores censuravam de tal forma o conteúdo do jornal que eles acabaram por desaparecer (MARCILIO, 2005).

O mesmo acontece com o projeto Educom.rádio, realizado pelo Núcleo de Educomunicação da Escola de Comunicações e Artes da Universidade de São Paulo (NCE-ECAUSP), cuja proposta é promover ações de resistência ao poder dos media. No site do núcleo ${ }^{15}$ estão disponíveis alguns textos que avaliam o trabalho projeto Educom.rádio, que teve início em 2001. Patrícia Horta Alves e Cláudia Lago (2005), em seu texto Educom.rádio: uma política pública que pensa a mudança da prática pedagógica, disponível no site do NCE, fazem um primeiro balanço da atuação da educomunicação nas escolas públicas do município de São Paulo:

O educom.rádio é uma das atividades desenvolvidas pela SME (Secretaria Municipal de Educação) por meio do Projeto Vida, para atender à demanda legislativa que prevê ações ativas de prevenção à violência nas escolas. Dessa forma, constitui-se também como política pública e, portanto, é oferecido para o conjunto da rede municipal. Se atingir as metas previstas, ao final de 2004 terá sido levado a 455 escolas, alcançando cerca de 11.500 pessoas (entre adultos e jovens). (id., ibid.)

Em linhas gerais, o projeto constitui-se de palestras, cursos e oficinas de rádio, capacitando os participantes do projeto a utilizar o rádio na escola. As escolas participantes 
recebem um equipamento com o objetivo de que a escola monte sua própria rádio. A linguagem radiofônica foi escolhida por trabalhar com a oralidade e o trabalho em equipe, e por aumentar a auto-estima dos alunos, que se reconhecem como sujeitos da fala. Além disso, segundo o projeto, participando das oficinas e palestras, a escola terá a chance de se ressignifcar perante o aluno. Entretanto, segundo as autoras o projeto acaba por não realizar plenamente seus objetivos devido às "condições e contradições do ambiente escolar" (id., ibid.). Segundo elas, existem escolas em que a rádio acaba por ser censurada e controlada pelos diretores, que cerceiam a expressão dos alunos. A rádio acaba por ter uma programação que "acalma" os alunos, tocando músicas que não são de sua cultura, por exemplo.

É impressionante constatar que essa argumentação é a mesma em relação à criação e à desativação dos Jornais Infantis nas bibliotecas escolares, ocorrida nas escolas em 1930. A idéia principal da Educomunicação é levar a linguagem mediática para dentro da escola, como uma forma de "competência cultural" que os alunos adquirem ao conhecer o processo de produção de um programa mediático. Até que ponto essa competência dita cultural não é apenas um aprendizado técnico?

Sobre o conhecimento do processo de gravação de um programa de TV, Deleuze (2004) escreveu em seu livro Conversações:

Pesquisas recentes mostram que um dos espetáculos mais apreciados consiste em assistir um programa de televisão no estúdio: não é questão de beleza nem de pensamento, mas de estar em contato com a técnica, tocar a técnica. [...] A visita à fabrica, com sua disciplina severa, tornou-se o ideal do espetáculo (como se fabrica um programa?), e o enriquecedor é o valor estético supremo (“é enriquecedor"...). A enciclopédia do mundo e a pedagogia da percepção desmoronam, em favor de uma formação profissional do olho, um mundo de controladores e controlados que se comunicam através da admiração pela técnica, nada além da técnica. Por toda a parte a lente de 
contato. É aqui que seu otimismo critico se converte em pessimismo crítico. (id., ibid., 93)

É esse pessimismo crítico que queremos dar de presente aos nossos alunos, sejam eles crianças ou não? Para os filósofos pós-críticos, como Deleuze e Guattari, a verdade é uma construção, o sujeito e o objeto do conhecimento são construções do discurso e as idéias de subjetividade e consciência são extremamente úteis ao poder. A filosofia pós-crítica aceita que o poder é descentrado, está espalhado por toda a rede social. Por isso, desconfia de

$$
\text { [...] de qualquer postulação que tenha como }
$$
pressuposto uma situação finalmente livre de poder. Para as teorias pós-criticas o poder transforma-se, mas não desaparece. Nas teorias pós-criticas, o conhecimento não é exterior ao poder, o conhecimento não se opõe ao poder. $\mathrm{O}$ conhecimento não é aquilo que põe em xeque o poder: o conhecimento é parte inerente do poder. Em contraste com as teorias críticas, as teorias pós-criticas não limitam a análise do poder ao campo das relações econômicas do capitalismo. Com as teorias pós-críticas, o mapa do poder é ampliado para incluir os processos de dominação centrados na raça, etnia, no gênero e na sexualidade. (SILVA, 2004, 149)

A filosofia pós-crítica rejeita a noção de consciência e de subjetividade, porque não acredita em nenhum processo de libertação que torne possível o surgimento de um Eu livre e autônomo, e olha com desconfiança para os conceitos de alienação, emancipação, libertação, conceitos que supõem uma subjetividade que precise ser restaurada.

Por isso, em relação à linguagem televisiva e ao próprio medium televisão visto tal como um agenciamento, Deleuze reconhece uma potência de criação que lhe é possível, uma possível função estética, uma aventura da percepção:

Como chegar a falar sem dar ordens, sem pretender representar algo ou alguém, como conseguir fazer falar 
aqueles que não têm esse direito, e devolver aos sons seu valor de luta contra o poder? Sem duvida, é isso, estar na própria língua como um estrangeiro, traçar para a linguagem uma espécie de linha de fuga. (DELEUZE, 2004, 56)

Dessa forma, podemos até utilizar as linguagens mediáticas na escola, não como uma forma de crítica ou de aquisição de uma competência cultural, mas como uma possibilidade de criação de agenciamentos que sejam diferentes do plano de organização a que os media pertencem. Em outras palavras, podemos utilizar as linguagens mediáticas na escola como estrangeiros, como uma criação artística. Ao encararmos a linguagem como uma função que agencia devires, e que pode ter um uso menor, desvinculado da Doxa e da significação, mudamos o modo como encaramos a cognição, que deixa de ser vista como recognição e passa a ser encarada como autoprodução. Essa forma de pensar nos liberta de agir pelo bom senso e pelo senso comum, e nos abre as portas para um saber que é passagem, construção, e não mais o saber absoluto.

Mas, antes de se propor qualquer método de ensino e de aprendizado, há que se definir qual é a finalidade do ensinar e do aprender. E isso é função da filosofia. A filosofia de Deleuze e Guattari não chegou a abordar diretamente a questão da educação. Entretanto, em seu livro $O$ que é a filosofia, Deleuze e Guattari (2000) afirmaram existir uma "pedagogia do conceito". Nesse livro, a pedagogia do conceito é apresentada como uma postura do pensamento que permite fugir do niilismo da Doxa (bom senso e senso comum) e do discurso pseudofilosófico da comunicação.

[...] todo o livro de Deleuze e Guattari parece concentrar-se, portanto na dupla tarefa - ontológica e política, teórica e pragmática - de ilustrar a natureza dessa pedagogia do conceito, e ao mesmo tempo, pô-la em prática [...] (BIANCO, 2005, 1290) 


\section{$3^{\circ}$.1. A PEDAGOGIA DO CONCEITO}

Para Deleuze e Guattari (ibid.), o conceito possui um estatuto pedagógico, ou seja, existe uma "pedagogicidade" que é do conceito. Portanto, faz-se necessário definir o que é conceito na visão deleuzeana. A principal crítica da filosofia de Deleuze e Guattari é em relação à imagem do pensamento como representação, pois para os filósofos o pensamento como representação é incapaz de pensar a diferença em si mesma, reduzindo-a à tranqüilizadora identidade do conceito já criado, à Idéia. Essa imagem clássica do pensamento não entende um método para o pensar porque já o condiciona a uma imagem implícita e pré-filosófica que entende que o pensamento possua uma boa natureza e uma boa vontade, que o pensador queira naturalmente o verdadeiro e que o pensamento tenha uma afinidade com a verdade (bom-senso). Dessa forma, o pensamento passa a ser uma atividade servil, relacionada às soluções cujas condições já estão dadas. Em outras palavras: o pensamento representacional faz perguntas já formuladas e dá respostas prédeterminadas. Entretanto, Deleuze e Guattari não contrapõem o conceito à intuição, porque para eles isso seria cair em um pessimismo filosófico sem saída.

Para Deleuze e Guattari ${ }^{16}$, a filosofia não é a busca pela verdade, ela é a criação de conceitos, é a $\operatorname{arte}^{17}$ de fabricar conceitos. A verdade é tão somente o que o pensamento cria. Ela nem mesmo é a razão pela qual o filósofo cria e potencializa conceitos, pois é o gosto filosófico que cumpre essa tarefa. O gosto filosófico é uma faculdade instintiva (sapere instintivo), responsável pela criação dos conceitos e é o motivo pelo qual o filósofo escolhe determinados problemas e escolhe determinados componentes para criar um conceito. Um conceito filosófico, por essa via, surge somente a partir de um problema mal resolvido. Todo conceito remete a um problema, e é em função de um problema que ele é criado. O conceito diz sobre o acontecimento não sobre a essência das coisas, e é auto-referencial: põe a si mesmo e põe seu objeto ao mesmo

\footnotetext{
${ }^{16}$ Nesse tópico, abordarei as idéias de Deleuze e Guattari expostas no livro $O$ que é a filosofia? Rio de Janeiro: Ed. 34, 2000.

${ }^{17}$ Ao contrario da tradição filosófica clássica, para a filosofia deleuzeana arte não é techné, é criação.
} 
tempo em que é criado. Por isso, deve estar relacionado com os problemas, com a história e com os devires. Ele é uma construção que se instaura num plano de imanência, ele é uma região do plano de imanência e é confuso, não discursivo, em deslocamento sobre o plano de imanência.

O plano de imanência é a imagem do pensamento que é construída pelo movimento infinito. O plano de imanência é nomeado pré-filosófico não porque existe antes de ser traçado, mas porque é traçado como pressuposto.

$\mathrm{O}$ conceito tem como constructo um personagem conceitual. Os personagens conceituais são os verdadeiros sujeitos da filosofia. O personagem conceitual e o plano de imanência estão em pressuposição recíproca, ora o personagem parece proceder ao plano, ora seguí-lo. Os diferentes planos se agrupam ou se separam segundo os pontos de vista constituídos pelos personagens conceituais.

A relação das três instâncias - conceito, plano e personagem - é, por natureza, problemática. Um conceito só tem sentido em relação a um plano de imanência e a um personagem conceitual. Por isso, os filósofos afirmam que a filosofia se dissolve no paradoxo: em cada uma das suas três atividades, criar conceitos ou solucionar problemas, traçar um plano ou suscitar um problema, inventar um personagem ou carregar incógnitas, não é encontrado critério senão nas outras duas. Elas se inter-relacionam e dependem uma das outras.

Para a filosofia deleuzeana, a ciência não se ocupa de conceitos, e sim de funções que se apresentam em forma de proposições, instaurando um plano de referência. A ciência é paradigmática, luta para dominar o caos e transformá-lo em função, em verificação. A ciência é testável e refutável.

Os conceitos materializam-se em figuras paradigmáticas. As figuras projetadas sobre um plano de imanência são figuras do conceito, já as figuras projetadas num plano de composição são figuras da arte. As figuras estéticas, e o estilo que as cria, são sensações: perceptos e afectos, paisagens e rostos, visões e devires. Os perceptos são enlaces de forças e os afectos, devires. Os perceptos e os afectos são compostos das forças não-humanas do cosmos, dos devires não humanos do homem. A arte tem por objetivos arrancar os perceptos das percepções do objeto e dos estados de um sujeito percipiente, e arrancar o afecto das afecções, como passagem de um estado a outro. A arte não é o caos, mas uma composição do caos, que dá a visão ou a sensação, constituindo um caosmo, como diz Joyce, um caos composto. 
A arte precisa de um método que varie com cada autor e que faça parte da obra. A obra de arte é um bloco de sensações, isto é, um composto de perceptos e afectos. E é exatamente este bloco que se conserva. A obra de arte é um ser de sensação: ela existe em si. A verdadeira obra de arte é aquela que consegue tornar um momento do mundo durável ou fazê-lo existir por si.

A obra de arte se dá num plano de composição. O plano de composição se constrói à medida que a obra avança, abrindo, misturando, desfazendo e refazendo compostos cada vez mais ilimitados. O plano de composição estética não vem antes dos compostos de sensações, não sendo preconcebido, não tendo nada a ver com um programa, mas também não vem depois, embora a tomada de consciência do personagem conceitual se faça progressivamente e surja freqüentemente depois. A arte e a filosofia recortam o caos, e o enfrentam, mas não no mesmo plano de corte. A arte não pensa menos que a filosofia, mas pensa por afectos e perceptos.

O plano de composição da arte, o plano de imanência da filosofia e o plano de referência da ciência deslizam um no outro, transversalmente, a ponto de certas extensões de um sejam ocupadas por entidades do outro. Os três planos devem lutar com o caos e com sua instância contraposta: a Doxa (o bom senso e o senso comum). A Doxa, a Opinião, o bom senso e o senso comum são inúteis para o pensamento porque coincidem com o dogmatismo, a anticriação. "Por isso, a filosofia não pode ser comunicação: para comunicar é preciso ter um conjunto de conjunto de coordenadas comuns que coincidam com a opinião” (BIANCO, 2005, 1298).

Todas as atividades criadoras constituem um ato de resistência à Doxa e à comunicação. Essa é a nova função do pensamento proposta por Deleuze e Guattari. Um pensamento transdisciplinar, transversal, que começa sempre pela diferença, no meio de alguma coisa, a partir de um acontecimento que faça sentido e que force o pensador a pensar, a criar conceitos, e não a "reconhecer" a Idéia. Esse é o eterno retorno do diferente. Para a imagem dogmática e clássica do pensamento, o professor formula questões que possuem respostas prontas. Para o pensamento sem imagem, os problemas se dão e com eles, suas soluções. Assim, os principais elementos do pensamento não são as categorias do verdadeiro e do falso, são, isso sim, o interessante e o não interessante, aquilo que tem sentido e aquilo que não tem. Muitas vezes, o interessante é aquilo que não tem sentido, mas que possibilita a sua construção. Ao invés de boa vontade do pensador, o pensamento sem imagem busca favorecer o encontro do pensador com forças que façam o pensamento ultrapassar o seu estado de torpor. 
Compreender que o pensamento possui uma função criadora modifica totalmente o modo como compreendemos o saber que agora pode ser definido também como uma função e não como uma forma ou uma força. Nesse sentido, a aprendizagem passa a implicar o criar, e não as soluções ou a Idéia (DELEUZE, 1998). Por essa via, o aprender torna-se a passagem viva entre não-saber e saber e transforma-se numa tarefa infinita, não subordinada ao ideal do saber absoluto e a errância passa a fazer parte da relação processual de construção do sentido. Assim, reconhece-se que é do aprender e não do saber que a condição transcendental do pensamento deve ser extraída, principalmente porque o tempo do pensamento é puro ou uma condição de direito (o tempo se apodera do pensamento) e não é o tempo empírico do pensador submetido a condições de fato. Conseqüentemente, o ensinar passa a ser encarado como um ato de colocar problemas aos alunos, e a avaliação do aprendizado deve ser do processo de construção e solução dos problemas, e não apenas da solução adequada à Idéia.

Silvio Gallo (2005), em seu livro Deleuze e a educação, propõe uma apropriação das idéias de Deleuze e Guattari não como “'verdades deleuzeanas sobre problemas educacionais'. De verdades - falsas verdades, diga-se de passagem - e de certezas - também falsas - a doxografia educacional está repleta” (id., ibid., 63). Mas, uma apropriação que possibilite pensar o novo sobre a educação. Para tanto, Gallo faz deslocamentos ${ }^{18}$ dos conceitos deleuzeanos para o plano de imanência da educação. Gallo propõe uma Pedagogia do Acontecimento, uma pedagogia que aceite a educação como acontecimento, um conjunto de acontecimentos.

Um dos deslocamentos propostos por Gallo é desvincular a relação educação-controle. A educação sempre pretendeu o controle social, a preparação social do aluno, sua inserção na máquina de Estado. Para isso, sempre estipulou papéis claros em relação ao poder na educação: o professor detém o poder sobre seus alunos. Por essa via, o uso de mecanismos de avaliação possui um claro apelo disciplinar e controlador. Gallo questiona todas essas formas de dominação em que o professor se sente sujeito de um processo em que, na verdade, ele é apenas mais um sujeitado. "Somos todos escravos", como disse Deleuze (apud GALLO, 2005). Portanto, devemos desconfiar de qualquer poder que o professor pense ter sobre seus alunos, e vice-versa. Devemos, isso sim, agir "sem nunca saber qual será o resultado de nossas ações” (id., ibid., 103). A tática sugerida pelo filósofo é o reconhecimento de nossos erros, e em conseqüência, do

\footnotetext{
${ }^{18}$ Um deslocamento é o que Deleuze chama de "roubo conceitual". É trazer um conceito filosófico para a ciência ou para a arte e vice-versa.
} 
erro de nossos alunos. Ou seja, uma forma de avaliação não punitiva e que reconheça o erro como parte do processo educativo.

Devemos, penso, começar por abdicar do discurso do poder. Não podemos defender a rigidez do sistema de notas/avaliação que culmina na reprovação, pois subjaz a ele nosso sádico desejo despótico, que é o mesmo que move as ações oficiais. (id., ibid., 112)

\section{$3^{\circ}$.1.1. Currículo e pós-estruturalismo}

Outra conseqüência dos conceitos deleuzeanos para a pedagogia é em relação ao currículo. Silvio Gallo (ibid.) propõe o rizoma como conceito para a construção de currículos. Ele propõe que se descarte a disciplinarização, fruto de uma noção de saber dogmática, e que em seu lugar se desenvolva um currículo rizomático. Entretanto, essa abordagem não concorda com as

propostas de interdisciplinaridade que são oferecidas atualmente. Essa interdisciplinaridade é horizontal e vertical, não é transversal. Um currículo rizomático é transdisciplinar. A transversalidade rizomática reconhece a pulverização, a multiplicidade, as diferenças e os trânsitos entre os saberes, sem procurar integrá-los artificialmente. Para tanto, Gallo propõe um currículo transversal e rizomático que deixe de lado a pretensão cientifica e massificante da Pedagogia.

Tomaz Tadeu da Silva (2004), propôs, em seu livro Documentos de identidade, uma introdução às teorias do currículo, que o currículo é lugar, é território, e por isso, é relação de poder. Numa perspectiva pós-estruturalista, da qual a filosofia deleuzeana faz parte, o conhecimento é encarado como indeterminado e incerto, algo socialmente produzido. Dessa forma, mais do que buscar um referente para a produção de um currículo escolar, o mais importante é examinar as relações de poder envolvidas em sua produção. Além disso, a perspectiva pós-estruturalista desconfia das definições filosóficas de "verdade". Por isso, busca analisar até que ponto um currículo escolar carrega verdades implícitas. Além disso, não propõe uma revolução curricular, nem um modelo de currículo "verdadeiro". 
Silva (ibid.) propõe um exemplo de currículo baseado nas idéias da filosofia pós-critica. Nesse currículo, os significados transcendentais (ligados à religião, à pátria, à política, à ciência) seriam questionados: onde, quando, por quem foram eles inventados? Além disso, nesse currículo, os inúmeros binarismos de que é feito o conhecimento seriam desconstruídos: masculino/feminino, heterossexual/homossexual, branco/negro, cientifico/não cientifico. Outra alteração proposta por um currículo pós-estruturalista seria questionar toda forma de separação por gêneros do conhecimento, tais como sujeito e objeto, e proporia a análise de conceitos como emancipação e libertação. 


\section{$3^{\circ}$.2. POR UMA DIDÁTICA DA OBRA DE ARTE}

A principal função da pedagogia é criar um conjunto de métodos que assegurem a assimilação do saber pelo aprendiz. Contudo, para tanto, é preciso definir primeiro quem é o aprendiz, como ele aprende e que tipo de inteligência se espera que ele desenvolva. Além disso, a didática deve orientar um método de ensino a ser usado pelo professor. Como já foi dito, a filosofia deleuzeana aceita que não existem seres e sim devires. Assim, como pensar o processo de cognição em devires? Como pensar a questão da inteligência numa base ontológica que aceita que os devires são múltiplos e que participam de agenciamentos coletivos? Como pensar a ação de um professor que não é um sujeito que ensina, mas sim, um bloco homem-signos-coisasanimais?

A pedagogia do século XX foi intensamente influenciada pelos estudos estruturalistas. Para o estruturalismo, a cognição é uma relação entre o sujeito e o objeto do conhecimento. Dessa forma, os estudos estruturalistas e os estudos das ciências cognitivas buscaram os princípios invariantes que condicionariam o funcionamento dessa relação. Segundo esse pensamento, o sistema cognitivo de um sujeito recebe informações, processa-as de acordo com regras lógicas e as transforma em representações, limitando o processo cognitivo a uma solução de problemas preconcebidos e resultando em respostas adequadas e previsíveis. Dessa forma, é muito difícil para esse modelo compreender a criação, porque, segundo ele, o que existe é sempre a recriação. Entretanto, já existem estudos que compreendem a cognição como uma criação.

\section{$3^{\circ}$.2.1. Autopoeise}

Poiesis é um termo grego que significa produção. Autopoiese quer dizer autoprodução. A palavra surgiu pela primeira vez na literatura internacional em 1974, num artigo publicado por Varela, Maturana e Uribe, para definir os seres vivos como sistemas que produzem continuamente a si mesmos. Para os biólogos, os seres vivos são autopoiéticos por definição 
porque recompõem continuamente os seus componentes desgastados, tornando-se, ao mesmo tempo, produtor e produto. Por essa via, a atividade cognitiva cotidiana é um verdadeiro criador de mundo.

[...] um sistema autopoético organiza-se como uma rede de processos de produção cujos componentes regeneram continuamente por suas transformações e interações a rede que os produziu e constituem o sistema como unidade concreta no espaço em que ele existe, especificando o domínio topológico no qual se realiza como rede. (MATURANA; VARELA apud MATELLART, A. E M., 2002, 163).

Essa forma de pensar a cognição revê o conceito de representação, pois vê a representação como uma criação da própria atividade cognitiva, e não como uma recriação do mundo préexistente. O sujeito e o objeto, o si e o mundo são efeitos da prática cognitiva, fazem parte da ação, da transformação permanente.

Para os biólogos, os seres vivos são máquinas que se definem por sua organização, por seus processos de conservação e que se diferem das outras máquinas por sua capacidade de se auto-reproduzir. A conservação é uma questão de desejo, de estética, de estar bem. Para eles, não há uma racionalidade no mundo, não há finalidade nele. Apenas existe um conjunto de interações num mundo que segue à deriva. O desejo de conservação, e conseqüentemente, de aprendizado, se constitui como uma busca de expressão, e não de representação.

De acordo com essas idéias, Deleuze afirma que o destino inconsciente do aprendiz é a arte (DELEUZE apud ALMEIDA, 2003). Esse desejo nasce da comunicação e da interação das partes de um sistema, e se dá na observação e no entendimento das mensagens que redundam no agenciamento. Por isso, autopoiese não quer dizer aprender sozinho ou espontaneamente. Pelo contrário, a idéia de autopoiese implica sempre a idéia de um agenciamento coletivo. 


\section{$3^{\circ}$.2.2. Inteligência coletiva}

Pierre Lévy (1998), em seu livro Inteligência coletiva, fez uma antropologia daquilo que ele chamou de espaços, conceito que possui um correlato com o conceito deleuzeano de agenciamento. Para o filósofo, o conceito de espaço antropológico desenha uma paisagem na qual são definidas as regras do jogo social e a identidade dos jogadores.

O que é um espaço antropológico? É um sistema de proximidade (espaço) próprio do mundo humano (antropológico), e, portanto dependente de técnicas, de significações, da linguagem, da cultura, das convenções, das representações e das emoções humanas. (id., ibid., 22).

Para Pierre Lévy (ibid.), o espaço que se delineia agora é o Espaço do Saber. Os espaços antropológicos anteriores (Terra - espaço de significação composto pela linguagem, pela técnica e pela religião, Território - espaço de significação composto pela linguagem, pela técnica, pela religião e pela escrita, e Mercadoria - espaço de significação composto pelo fluxo veloz de informações, mão-de-obra, mercadorias, capitais), vêm abrindo lugar ao Espaço do Saber, uma utopia proposta por Lévy.

Nesse espaço, "o saber, os conhecimentos vivos, as competências dos seres humanos estão prestes a serem reconhecidos como a fonte de todas as riquezas” (id., ibid., 24). Para tanto, ele propõe o uso das tecnologias da informação para “a criação de uma era pós-mídia, na qual as técnicas da comunicação servirão para filtrar o fluxo de conhecimentos, para navegar no saber e pensar juntos, em vez de carregar consigo massas de informação” (id., ibid., 24).

Para Lévy (ibid.), a inteligência coletiva é um tipo de inteligência que é distribuída por toda a parte e resulta de uma mobilização coletiva das competências. Para tanto, é necessário identificar as competências, reconhecê-las em sua diversidade, reconhecendo a inteligência do outro como válida.

$O$ ideal da inteligência coletiva implica numa valorização técnica, econômica, jurídica e humana de uma inteligência distribuída por toda a parte, a fim de desencadear 
uma dinâmica positiva de reconhecimento e mobilização das competências (id., ibid., 30)

A inteligência coletiva identifica-se com uma forma de cultura criada a partir da negociação permanente da ordem estabelecida, de sua linguagem, do papel de cada um, do discernimento e da definição de seus objetos, e a reinterpretação de sua memória. No espaço do saber, os indivíduos são reconhecidos como singulares, múltiplos, nômades, em vias de metamorfose (e de aprendizado) permanente. Nesse espaço, o ser é definido pelo conhecer.

Pierre Lévy (ibid.) propõe como "instrumento de navegação" nesse espaço o cinemapa. Num espaço do aprendizado permanente, a dificuldade está em "organizar o organizador, objetivar o subjetivante” (id., ibid., 163). Conhecer o conhecer pressupõe uma transformação do conhecimento, uma dinâmica de reavaliação contínua. Por isso, a cartografia do Espaço do saber precisa ser feita com a ajuda de um cinemapa, um instrumento que surge da interação em um universo informacional móvel, em um banco de dados constantemente renovado. O cinemapa é uma virtualização do atual, que se projeta "do presente para o futuro", mas finca suas raízes, ou alicerces, no processo de criação e gestação histórica.

No cinemapa, o universo informacional não é estruturado a priori, não é regulado. $\mathrm{O}$ cinemapa não é um planejamento, um programa. Ele é uma estratégia, um caminho, um sentido. Com o cinemapa, se desenha as proximidades entre os objetos, entre determinado objeto e determinado atributo. Cada ponto do cinemapa é um atributo diferente dos outros, uma qualidade específica, manifestada por um ícone, um signo único. Dessa forma, o cinemapa desenha um mosaico móvel, em permanente recomposição, no qual cada fragmento é uma figura completa, mas que adquire sentido somente a partir de uma configuração geral. O cinemapa mostra um filme contínuo de transformações, ele registra as transformações. Assim, ele é um importante instrumento de avaliação social.

Fazer um mapa é produzir uma fonte de informação que traz aspectos relevantes, pois ele não representa o território, mas sim um conjunto de certos aspectos do território e, por isso, ele é uma fonte de escolhas. Ele é um guia que mostra caminhos e facilita escolhas e ações, e pressupõe a autonomia do aprendiz. Por isso, é fundamental que o cartógrafo tenha clara a função do mapa, e também uma visão do contexto a ser mapeado e do contexto no qual o mapa será utilizado. 
Os participantes daquilo que Lévy chama de Intelectual Coletivo, os indivíduos, podem se situar no cinemapa, identificando-se. Entretanto, também podem encontrar novos caminhos, elaborar novas estratégias de navegação. Assim, o cinemapa permite orientar, preparar itinerários, estratégias, coordenar o interior de grupos humanos graças a representações comuns. O cinemapa acompanha as navegações do intelectual coletivo em seus mundos de conhecimentos, desenhando e redesenhando o Espaço do saber, e constituindo a autonomia desse espaço e de seus participantes. No espaço do saber, não existem identidades definidas: professor, aluno. Nesse espaço se dão devires.

\section{$3^{\circ}$.2.3. O agenciamento de ensino e de aprendizado}

Como já foi dito, os devires são blocos, matilhas, bandos. O devir mestre e o devir aprendiz se dão juntos, entretanto eles nada têm a ver com o sujeito que ensina e o sujeito que aprende. O devir mestre e o devir aprendiz se constituem em agenciamentos especiais, em agenciamentos de ensino e de aprendizado.

Deleuze, ao falar sobre sua experiência de quase 40 anos como professor na entrevista que concedeu a Claire Parnet chamada $O$ abecedário de Gilles Deleuze ${ }^{19}$, afirmou que uma aula é um espaço-tempo muito especial, que se estende em seqüência. Para o filósofo, existem duas concepções de aula: uma que tem como objetivo obter reações imediatas dos alunos, através do diálogo, e um outro tipo que ele chamou de musical.

O que significa uma concepção musical de aula? Acho que são duas coisas, na minha experiência, sem dizer que essa é a melhor concepção. [...] Conhecendo um público, o que foi meu público, penso: "Sempre tem alguém que não entende na hora. E há o que chamamos de efeito retardado". Também é como na música. Na hora, você não entende um movimento, mas, três minutos depois, aquilo se torna claro porque algo aconteceu nesse ínterim. Uma aula pode ter

${ }^{19}$ O Abecedário de Gilles Deleuze é uma realização de Pierre-André Boutang, produzido pelas Éditions Montparnasse, Paris. No Brasil, foi divulgado pela TV Escola, Ministério da Educação. Tradução e Legendas: Raccord [com modificações]. A série de entrevistas, feita por Claire Parnet, foi filmada nos anos 1988-1989. 
efeito retardado. Podemos não entender nada na hora e, dez minutos depois, tudo se esclarece. Há um efeito retroativo. [...] É por isso que as interrupções e perguntas me parecem tolas. Você pergunta porque não entende, mas basta esperar. [...] (id., ibid.)

Para o filósofo, uma aula não tem que ser entendida totalmente, no mesmo instante em que é dada, mas sim, tem que ser vista como uma matéria em movimento. Como quando ouvimos uma música, que da primeira vez, não gostamos, mas que passamos a fruir com a repetição e com o passar do tempo.

Numa aula, cada grupo ou cada estudante pega o que lhe convém. Uma aula ruim é a que não convém a ninguém. [...] Uma aula é emoção. É tanto emoção quanto inteligência. Sem emoção, não há nada, não há interesse algum. Não é uma questão de entender e ouvir tudo, mas de acordar em tempo de captar o que lhe convém pessoalmente. (id., ibid.)

Desse modo, um agenciamento de ensino e de aprendizado constitui-se como um espaço de expressão e de enunciação. E, por isso, nele existem estratos que possuem diferentes modos de expressão e de enunciação. O devir mestre deve estar atento ao modo como se dão a expressão e a enunciação em cada estrato do agenciamento de ensino e de aprendizado, por que é ele quem pode agenciar o devir aprendiz em seus alunos, é ele quem pode agenciar o desejo de aprender de seus alunos em cada estrato do agenciamento, e não usando apenas palavras de ordem.

Como já foi dito, pode-se dividir os estratos do agenciamento em três tipos: real-formal, real-real e real-essencial. Apenas o estrato real-essencial é linguageiro, opera por signos. $\mathrm{O}$ primeiro estrato, real-formal, é físico-químico, geológico. Nele, a expressão se dá por indução. Deleuze afirmou que "Uma aula quer dizer momentos de inspiração, senão não quer dizer nada" (id., ibid.). O devir mestre, dessa forma, ao invés de apenas transmitir informações, pode inspirar seus alunos, sem fala, sem signos codificados, como por inspiração.

O segundo estrato, real-real, é orgânico. Nele, a expressão se dá por transdução, por transferência molecular. O devir mestre, nesse estrato, pode expressar conhecimento por 
sensações, por trocas moleculares, sem fala, sem signos codificados. Como mostra esse pequeno trecho do diálogo Deleuze/Parnet:

GD: Eu ensinava meus alunos a tocar serrote porque eu tocava e todos achavam normal. Acho que, hoje, isso não seria mais possível...

CP: Pedagogicamente, queria explicar o quê com o serrote? Em que momento ele entrava em cena?

GD: As curvas. O serrote, como você sabe, tem de ser curvado e obtemos o som num ponto da curva. São curvas móveis que lhes interessavam muito.

CP: Já era sobre a variação infinita.

GD: Mas eu não fazia só isso. Eu seguia o currículo, era muito consciencioso.

(id., ibid.).

O terceiro e último estrato, real-essencial, é linguageiro. Nele, a expressão se dá por tradução, por transposição. Aqui, o devir mestre deve se preparar, organizar os signos, agenciar enunciados, amar o assunto da aula:

É preciso estar totalmente impregnado do assunto e amar o assunto do qual falamos. Isso não acontece sozinho. É preciso ensaiar, preparar. É preciso ensaiar na própria cabeça, encontrar o ponto em que... É muito divertido, é preciso encontrar... É como uma porta que não conseguimos atravessar em qualquer posição. (id., ibid.)

Além disso, nesse estrato do agenciamento escolar, o devir mestre usa a voz, a fala, a língua oral:

Uma aula implica vocalizações, implica até uma espécie de - eu falo mal alemão - Sprechgesang [canção do 
discurso]. Evidentemente. Há mitificações, "Viu as unhas dele?", etc. Faz parte de todos os professores. Desde o primário é assim. O mais importante é a relação entre a voz e o conceito. (id., ibid.)

No estrato linguageiro, o devir mestre traduz o conhecimento em palavras de ordem, em territorializações técnicas e tecnológicas, redundando mensagens de forma intensa e cujos meios são os valores como o amor, a amizade, o respeito, o dinheiro, o poder, etc.. Nesse espaço, o plano de referência da ciência se configura em proposições, em paradigmas, a fím de dominar o caos e transformá-lo em verificação.

Entretanto, no agenciamento de ensino e de aprendizado também acontecem desterritorializações, fugas, e a linguagem se apresenta como agramatical, menor, constituindo a possibilidade para a criação de um plano de composição da arte. É aí que podem surgir as obras de arte, as figuras estéticas, novos seres, novas formas. E é aí que o devir mestre redunda informações e observa o agenciamento a fim de manter a autoprodução do agenciamento. Numa educação rizomática, o devir mestre deve estar atento ao movimento de territorialização, desterritorialização e reterritorialização dos devires, e para isso, traçar o cinemapa, o mapa dos movimentos no agenciamento, pode ser muito útil. Assim, o devir mestre deve ser, também, um devir cartógrafo, aquele que traça o mapa do agenciamento do qual participa. Fazer mapas orgânicos, ecológicos, tecnológicos a serem estendidos no plano de consistência da filosofia, no plano da criação de conceitos.

Deleuze e Guattari (1995a) comentam que os mapas abrem novos caminhos, possibilitam descobrir novos atalhos e estabelecer novas conexões. Os mapas não têm um único ponto de chegada ou de partida, devem ser flexíveis e estar em contínua atualização, e por isso, são continuamente construídos.

O mapa não reproduz um inconsciente fechado sobre ele mesmo, ele o constrói. Ele contribui para a conexão dos campos, para o desbloqueio, para uma abertura máxima sobre um plano de consistência. O mapa é aberto, é conectável, em todas as suas dimensões, desmontável, reversível, suscetível de receber modificações 
constantemente. Ele pode ser rasgado, revertido, adaptar-se a montagens de qualquer natureza, ser preparado por um indivíduo, por um grupo, uma formação social. Um mapa tem múltiplas entradas. (id., ibid., 22)

E eu acrescentaria: múltiplas saídas. 


\section{$3^{\circ}$.3. CONCLUSÃO}

Minha experiência como professora de Arte é curta, porém intensa. Depois de mais de dez anos trabalhando na área de comunicação, há sete venho atuando em sala de aula: por quatro anos trabalhei como professora de Arte na Educação Infantil e no Ensino Fundamental e há três, formo professores em arte. Atualmente, leciono a disciplina Conteúdo e Metodologia da Arte e a disciplina Educação e Tecnologias da Comunicação e da Informação no curso de Pedagogia de uma universidade. Sou, também, autora de livros didáticos e paradidáticos e de cursos on-line. Por isso, não posso deixar de pensar que, se para Deleuze e Guattari existe uma pedagogia que é do Conceito, existe também uma didática que é $d a$ Obra de Arte.

Para a filosofia clássica, os sujeitos percebem o mundo a fim de entendê-lo e através da razão, da linguagem representacional, da intersubjetividade e da comunicação dialógica, trocam informações codificadas e verdadeiras sobre seu entendimento do mundo com outrem. Para essa forma de pensar, o conhecimento é aprendido e alcançado quando ressignificamos o mundo e o representamos adequadamente.

A filosofia deleuzeana, entretanto, entende que os afectos (devires, rostos) e os perceptos (paisagens, enlaces de forças) se dão em agenciamentos do plano da Imanência, ou do pensamento sem imagem, traçado pela Máquina Abstrata. O que move a máquina, aquilo que faz acontecer, é o desejo, ou as relações de força que se dão nos fluxos presentes nos agenciamentos, conjuntos de vizinhança homem-utensílio-animal-coisa. Nos agenciamentos, o sentido é imanente e é sempre uma autoprodução do sistema que se renova constantemente, num Eterno Retorno do Diferente.

Nos diferentes estratos do agenciamento, não existem sujeitos que se comunicam através de informações codificadas, mas sim máquinas de expressão e enunciados coletivos. No estrato linguageiro, a linguagem pode ser usada de forma gramatical, onde os meios são os valores, ou pode tender ao agramatical, sem sentido, non-sense. 
Os agenciamentos são recortados pelo plano de referência das ciências, e de suas proposições, pelo plano de consistência da filosofia, e de seus conceitos, e pelo plano de composição da arte, e de suas obras. Por isso, para a filosofia deleuzeana, o saber é uma construção de conceitos (no plano da filosofia), de obras de arte (no plano da arte), de proposições (no plano das ciências), é transdisciplinar e vive em constante transformação, sempre em movimento, sempre em construção.

Por essa via, conhecer não é ressignificar e representar, é criar sentido e expressar, e o aprendizado é uma passagem viva entre não-saber e saber: uma tarefa infinita.

Nos momentos em que um agenciamento é recortado pelo plano de composição da arte, entendida como criação e não como techné, afectos e perceptos misturam-se, amalgamam-se, perdem sua configuração original e se transformam num turbilhão de diferenças em processos de inovação. Ali acontece uma instabilidade criativa que afeta todo o sistema e a linguagem passa a agir como um vírus, como afirmava William Burroughs, redundando mensagens com o único fim de manter o agenciamento. Nesse momento, a comunicação é mediada pelos valores que podem manter, ou não, o agenciamento original.

O plano de composição da arte constitui um caosmo, uma forma de organização do caos. Ele se constrói na medida em que a obra de arte avança, abrindo, misturando, desfazendo e refazendo compostos cada vez mais ilimitados, e conserva os blocos de afectos e perceptos, os quais organiza, preserva. Para tanto, possui um método que varia com cada autor e que faz parte de cada obra de arte.

O método de criação não se baseia na transmissão e ressignificação de mensagens claras verdadeiras. Pelo contrário, ele se baseia na redundância de mensagens num agenciamento e se transforma a cada vez que o sentido se dá. O momento da criação num agenciamento é o momento do novo.

A obra de arte é um composto de perceptos e afectos, é um ser de sensação: ela existe em si. A verdadeira obra de arte conserva afectos e perceptos e renova o agenciamento, tornando-o diferente, transformando-o. Na produção desse novo agenciamento, nessa autopoiese, a Máquina Abstrata desenha uma nova paisagem, reterritorializa-se. E as obras de arte configuram-se como marcos, pontos cardeais que conservam momentos e permitem a criação de mapas do plano de Imanência. Os mapas são instrumentos para conhecer o conhecer, e surgem da interação em um universo informacional móvel, em um banco de dados constantemente renovado. 
Fazendo um deslocamento dessas idéias para a didática, podemos pensar que o momento de autopoeise ou de autoprodução num agenciamento de ensino e de aprendizado pode ser visto como o momento do entre-ensino. O entre-ensino acontece na desterritorialização dos devires, acontece no momento em que a máquina de expressão tende ao agramatical. Nesses momentos, o professor deve estar atento à construção de sentido no agenciamento.

O principal objetivo de se compreender o entre-ensino é trazer a errância para perto do professor. Ensinar significa também aventura e abertura ao diferente, com tudo o que isso implica em termos de risco e de esforço. Mais do que valorar as verdades possíveis, para mim, a educação deve juntar uma verdade particular a um contexto global e a didática deve compreender o uso menor da linguagem e da comunicação. É preciso que o espírito se arrisque a ir até onde faltam todos os abrigos, como afirma Michel Serres. Numa sociedade que se pretende educativa, o papel do professor não pode ficar confinado ao de um mero transmissor de verdades feitas.

Além disso, quando o sentido se dá e um novo conhecimento surge dentro do processo de construção de um saber transdisciplinar, uma nova figura se apresenta no agenciamento. Essa figura, conceitual, proposicional ou estética, é um marco no fluxo, um ponto cardeal que pode servir para que o professor trace o cinemapa, o mapa do movimento do saber no agenciamento de que participa, transformando, assim, o professor num cartógrafo, em alguém em busca de novos caminhos, novas saídas, novos atalhos.

Nesse quadro, a formação do professor deve ser vista como uma oportunidade de exercício de autonomia e de maturidade profissional. O papel do professor é o de alguém atento, preparado, "ensaiado", um ser que inspira seus alunos por ser um verdadeiro apaixonado pelo saber nômade. O devir mestre deseja um agenciamento que propicie a interação no espaço da sala de aula e constrói seu próprio método.

Finalizo minha dissertação afirmando o desejo de continuar, em meu doutorado, a pesquisa sobre isso que chamei de Didática da Obra de Arte, e faço minhas as palavras de Fernando Pessoa:

Sinto-me nascido a cada momento

Para a eterna novidade do Mundo... 


\section{BIBLIOGRAFIA}

\section{Livros:}

ALMEIDA, Julia. Estudos deleuzeanos da linguagem. São Paulo: Unicamp, 2003.

BAUMAN, Zygmunt. Modernidade líquida. RJ, Zahar, 2001. . O mal-estar da pós-modernidade. RJ, Zahar, 1998.

Bíblia Sagrada, edição pastoral. São Paulo: Paulus, 1990.

BRASIL. Secretaria de Educação Fundamental. Parâmetros curriculares nacionais: arte / Secretaria de Educação Fundamental. - Brasília : MEC / SEF, 1998.

CHAUÍ, Marilena. Convite à filosofia. São Paulo: editora Ática, 2004

CORAZZA, Sandra Mara. Infância e educação. Rio de Janeiro: Vozes, 2002.

DAMIS, Olga Teixeira. Didática e ensino: relações e pressupostos in Repensando a didática. São Paulo: Papirus, 2005.

DELEUZE, Gilles e GUATTARI, Félix. Mil Platôs. Vol. 1. São Paulo: editora 34, 1995 a. .Mil Platôs. Vol.2. São Paulo: editora 34, 1995 b. .Mil Platôs. Vol. 3. São Paulo: editora 34, 1996. .Mil Platôs. Vol. 4. São Paulo: editora 34, 1997. . O que é a filosofia? São Paulo: editora 34, 2000.

DELEUZE, Gilles e PARNET, Claire. Diálogos. São Paulo, editora Escuta, 1998. DELEUZE, Gilles. Conversações. São Paulo: editora 34, 2004. .Diferença e repetição. Rio de Janeiro: edições Graal, 1998. .Espinosa, filosofia prática. São Paulo: editora Escuta, 2002. .Foucault. São Paulo: Brasiliense, 1995. .Lógica do sentido. São Paulo: editora Perspectiva, 2003.

DEWEY, John. Democracia e educação. São Paulo: Companhia editora Nacional. 1979. FOUCAULT, Michel. A Ordem do Discurso. São Paulo: Edições Loyola. 1998. . A arqueologia do saber. Rio de Janeiro: Forense Universitária, 2004. . Aula de 17 de março de 1976 in Em defesa da sociedade. São Paulo:

Martins Fontes, 1999. 
. Estruturalismo e teoria da linguagem. Petrópolis: Editora Vozes, 1971.

. O sujeito e o Poder in Dreyfus, H. e Rabinow, P., Michel Foucault,

uma trajetória filosófica. RJ, Forense Universitária, 1995.

FREUD, SIGMUND. O mal-estar da civilização. R J. Imago, 1997.

GALLO, Silvio. Deleuze e a educação. MG: editora Autentica. 2005.

GHIRALDELLI JR., Paulo. Infância, educação e neoliberalismo. São Paulo: Cortez, 2000.

GUATTARI, Felix e ROLNIK, Suely. Micropolitica, cartografias do desejo. Rio de Janeiro: Vozes, 2005.

GIDDENS, Anthony. As conseqüencias da modernidade. SP, UNESP, 1991.

HALL, Stuart. A identidade cultural na pós-modernidade. SP, DP\&A, 2001.

IAVELBERG, Rosa. Para gostar de aprender arte. Porto Alegre: Artmed, 2003.

JAPIASSU, Hilton. Introdução ao pensamento epistemológico. Rio de Janeiro: Francisco Alves. 1991.

KERÉNYI, Karl. Os deuses gregos. São Paulo: Cultrix, 2000.

KUPSTAS, Márcia. Comunicação em debate. São Paulo: Moderna, 1997.

LÉVY, Pierre. A inteligência coletiva, por uma antropologia do ciberespaço. São Paulo: Loyola, 1998.

LIBÂNEO, José C. Democratização da escola pública. São Paulo, Edições Loyola, 1985.

LOPES, Maria Immacolata Vassalo de. Apresentação in Epistemologia da Comunicação, São Paulo: Loyola, 2003.

LYOTARD, Jean-François. A condição pós-moderna. Rio de Janeiro: José Olympio, 1998 MACHADO, Nilson José. Epistemologia e didática. São Paulo: editora Cortez. 1999.

MATELlART, Armand e Michèle. História das teorias da Comunicação. São Paulo: edições Loyola, 2002.

MARCÍLIO, Maria Luiza. A história da escola em São Paulo e no Brasil. São Paulo: Imprensa Oficial do Estado de São Paulo, 2005.

MARCONDES FILHO, Ciro. O escavador de silêncios. São Paulo: editora Paulus, 2004.

MARTÍN-BARBERO, Jesús. De los medios a las mediaciones: comunicación, cultura y hegemonia. México: Gustavo Gilli, 1987. 
MORIN, Edgar. Os setes saberes necessários à educação do futuro. São Paulo: Cortez, 2000 .

PASSOS, Fernando. Arte, comunicação e ciência - a questão da linguagem. In Epistemologia da Comunicação, São Paulo: Loyola, 2003.

PELBART, P. O tempo não reconciliado. São Paulo: Perspectiva, 1998.

PROST, Antoine, e VINCENT, Gerard. História da vida privada: da Primeira Guerra aos dias atuais. São Paulo: Companhia das letras, 1995.

SERRES, Michel. A Lenda dos Anjos. São Paulo: Aleph, 1995.

SINGER, Helena. República de crianças. Sobre experiências escolares de resistência. São Paulo: editora Hucitec, 1997.

SILVA, Tomaz Tadeu da. Documentos de identidade, uma introdução às teorias do currículo. Belo Horizonte: Autentica, 2004.

SOUSA, Mauro Wilton de. O lugar social da comunicação mediática, in Caminhos da educomunicação, Cadernos da educomunicação, volume 1, NCE- ECA-USP. São Paulo: Salesiana, 2001.

VEIGA, Ilma Passos Alencastro. Didática, uma retrospectiva histórica in Repensando a didática. São Paulo: Papirus, 2005.

WANDERLEY, Luiz Eduardo. Educar para transformar. Igreja Católica e Política no Movimento de Educação de Base. Petrópolis. Vozes, 1984.

\section{Periódicos:}

BIANCO, Giuseppe. Otimismo, pessimismo, criação: pedagogia do conceito e resistência. Revista Educação \& Sociedade, Campinas-SP, v. 26, n. 93, p. 1289-1308, set./dez. 2005.

CHOPPIN, Alain. História dos livros e das edições didáticas: sobre o estado da arte. Revista Educação e Pesquisa, São Paulo, v. 30, n. 3, p.549-566, set./dez. 2004.

KASTRUP, Virgínia. Políticas cognitivas na formação do professor e o problema do devir-mestre. Revista Educação \& Sociedade, Campinas-SP, v. 26, n. 93, p. 1273-1288, set./dez. 2005. 
MEDRANO, Eliziara M. O. e VALENTIM, Lucy M. S. A indústria cultural invade a escola brasileira. Cadernos Cedes, Campinas-SP, ano XXI, n. 54, p. 69-75, agosto 2001.

MOTTA, Carlos E. de S. Indústria cultural e o sistema apostilado: a lógica do capitalismo. Cadernos Cedes, Campinas-SP, ano XXI, n. 54, p. 82-89, agosto 2001.

\section{Documento de acesso eletrônico:}

ALVES, Patrícia Horta e LAGO, Cláudia. Educom.rádio: uma política pública que pensa a mudança da prática pedagógica. São Paulo, 2005. Disponível em:

$<$ http://www.usp.br/nce/aeducomunicacao/saibamais/textos/_>. Acesso em: 14 jul. 2005.

COMENIUS, Iohannis A. Didática Magna. Moravia, 1633. Fundação Calouste Gulbenkian, 2001. Versão para eBook eBooksBrasil.com. Disponível em:

$<$ http://www.culturabrasil.org/didaticamagna/didaticamagna-comenius.htm $>$. Acesso em: 20 set. 2005.

DELEUZE, Gilles. Desejo e prazer. Paris, 1994. Disponível em:

$<$ http://www.unb.br/fe/tef/filoesco/foucault/art07.html> Acesso em: 18 set. 2005.

DELEUZE, Gilles e PARNET, Claire. O abecedário de Gilles Deleuze. Disponível em: < http://www.oestrangeiro.net/index.php?option=com_content\&task=view\&id $=67 \&$ Itemid $=51>$. Acesso em 10 nov. 2005.

FILOCOM. Nova teoria da Comunicação. São Paulo, 2004. Disponível em: $<$ http://www.eca.usp.br/nucleos/filocom/home.html > . Acesso em: 04 de jul. 2005.

GHIRALDELLI, Paulo. As terminologias em filosofia da educação no debate sobre formação de professores. São Paulo, 2002. Disponível em: $<\mathrm{http} / / /$ www2.uol.com.br/aprendiz/n_colunas/coluna_livre/id071003.htm>. Acesso em: 17 out 2005.

GOLFE, Osvaldo Luis. Antonio Gramsci, uma alternativa para o marxismo. São Paulo, 1999. Disponível em: < http://www.rubedo.psc.br/Artigos/gramsalt.htm\#FOOTNOTE>. Acesso em: 31 maio 2005.

PERRENOUD, Philippe. Os dez não-ditos ou a Face escondida da profissão docente. Genebra, 1999. Disponível em: 
$<$ http://www.unige.ch/fapse/SSE/teachers/perrenoud/php_main/php_1999/1999_42.html>. Acesso em: 15 set. 2005.

ROUSSEAU, Jean Jacques. O Emilio ou Da educação. Genebra, 1762. Disponível em: $<$ http://www.spleb.org.br/pt/lv/o_emilio.php> . Acesso em: 5 de out. 2005.

SERRES, Michel. A sociedade pedagógica. Texto de abertura da edição de "Le Monde de L’Éducation - de la culture et de la formation”. Paris, 1998. Disponível em: $<$ http://caosmose.net/candido/traducoes/sociedadepedagogica.pdf > . Acesso em: 07 out. 2005.

SOARES, Ismar de O. Mas, afinal, o que é educomunicação? São Paulo, 2004.

Disponível em: $<$ http://www.usp.br/nce/aeducomunicacao/saibamais/textos/> . Acesso em: 10 jul. 2005.

\section{Sites visitados:}

APRENDIZ: http://www2.uol.com.br/aprendiz

CAOSMOSE: http://caosmose.net

IBGE: www.ibge.gov.br

MEC: http://portal.mec.gov.br

NCE-USP: http://www.usp.br/nce/

RIZOMA: http://www.corposem.org/rizoma 